\title{
ANGLE PERCEPTION ON AUTOSTEREOSCOPIC DISPLAYS
}

\author{
A THESIS SUBMITTED TO \\ THE GRADUATE SCHOOL OF INFORMATICS \\ $\mathrm{OF}$ \\ THE MIDDLE EAST TECHNICAL UNIVERSITY
}

BY

\begin{abstract}
ERSIN KARAMAN
IN PARTIAL FULFILLMENT OF THE REQUIREMENTS FOR THE DEGREE OF MASTER OF SCIENCE

IN

THE DEPARTMENT OF INFORMATION SYSTEMS
\end{abstract}

JULY 2009 
Approval of the Graduate School of Informatics

Prof. Dr. Nazife BAYKAL

Director

I certify that this thesis satisfies all the requirements as a thesis for the degree of Master of Science.

Prof. Dr. Yasemin YARDIMCI ÇETIN

Head of Department

This is to certify that we have read this thesis and that in our opinion it is fully adequate, in scope and quality, as a thesis for the degree of Master of Science.

Prof. Dr. Yasemin YARDIMCI ÇETIN

Supervisor

Examining Committee Members

Assist. Prof. Dr. Altan KOÇYİĞİT

(METU, II)

Prof. Dr. Yasemin YARDIMCI ÇETINN

(METU, II)

Dr. Hacer KARACAN

(GAZİ, CENG)

Assist. Prof. Dr. Sevgi ÖZKAN

(METU, II)

Assist. Prof. Dr. Alptekin TEMIZEL

(METU, II) 
I hereby declare that all information in this document has been obtained and presented in accordance with academic rules and ethical conduct. I also declare that, as required by these rules and conduct, I have fully cited and referenced all material and results that are not original to this work.

Name, Last Name: Ersin KARAMAN

Signature: 


\title{
ABSTRACT \\ ANGLE PERCEPTION ON AUTOSTEREOSCOPIC DISPLAYS
}

\author{
KARAMAN, Ersin \\ M.Sc., Department of Information Systems \\ Supervisor: Prof. Dr. Yasemin YARDIMCI ÇETIN
}

July 2009, 81 pages

Stereoscopic displays provide 3D vision usually with the help of additional equipment such as shutter glasses and head gears. As a new stereoscopic display technology, autostereoscopic 3D Displays provide 3D vision without additional equipment. 
Previous studies of depth and distance estimation with autostereoscopic displays indicate the users do not exhibit better performance in 3D. Yet, they claim 3D displays provide higher immersiveness.

In this study, perception of the angle of a $3 \mathrm{D}$ shape is investigated by comparing $2 \mathrm{D}$, $3 \mathrm{D}$ and Real perception cases. An experiment is conducted using an autostereoscopic 3D display. Forty people have participated in the experiment. They were asked to estimate the vertex angle and draw the projections of the object from two different viewpoints. It is found that users can better estimate the angles on a cone when viewed from the top on an autostereoscopic display. This may contribute positively to 3D understanding of the scene.

Results revealed that participants make more accurate angle estimation in autostereoscopic 3D displays than in traditional 2D displays. In general, the participants' angle drawings were slightly higher than their angle estimations. Moreover, the participants overestimated 35, 65 and 90 degree angles and underestimated 115 degree angle in autostereoscopic 3D display.

Keywords: Angle Perception, Autostereoscopic Display, Visual Cue, Depth Perception. 


\title{
AUTOSTEREOSKOPİK EKRANLARDA AÇI ALGISI
}

\author{
KARAMAN, Ersin \\ Yüksek Lisans, Bilişim Sistemleri Bölümü \\ Tez Yöneticisi: Prof. Dr. Yasemin YARDIMCI ÇETIN
}

Temmuz 2009, 81 sayfa

Bir çok stereoskopik ekran 3B algısını gözlük, kask gibi yardımcı araçlarla sağlamaktadır. Yeni bir stereoskopik ekran teknolojisi olarak, autostereoskopik ekranlar 3B görüntüyü yardımcı aparatsız sunmaktadırlar. 
Autostereoskopik ekranlarla derinlik ve uzaklık tahmini ile ilgili daha once yapılmış olan çalışmalar, kullanıcıların 3B ekranlarda daha iyi performans sergileyemediğini; bununla beraber 3B ekranların kendine bağlayıcılığının daha da fazla olduğunu ortaya koymuştur.

$\mathrm{Bu}$ çalışmada üç boyutlu şekil açılarının algısı, 2B, 3B ve gerçek ortamın karşılaştırması yapılarak araştırılmıştır. Çalışma kapsamında autostereoskopik 3B ekran kullanılarak bir deney yapılmıştır. Deneye kırk kişi katılmıştır. Katılımcılardan, iki faklı bakış açısından gösterilen nesnelerin tepe açılarını tahmin etmeleri ve nesnenin profilini çizmeleri istenmiştir. Kullanıcıların, autostereoscopic ekranlarda konilere üstten bakarak 2B ekranlara gore daha iyi tahmin yaptıkları saptanmıştır. Bu da ekrandaki üç boyut algısının daha iyi olduğunu göstermiştir.

Sonuçlar göstermektedir ki, katılımcılar geleneksel 2B ekranlara karşın autostereoskopik 3B ekranlarda daha isabetli açı tahmini yapmaktadırlar. Genel olarak katılımcıların çizdikleri nesne profillerindeki ölçülen açılar tahminlerine oranla az da olsa büyüktür. Ayrıca, katılımcılar autostereoskopik 3B ekranlarda 35, 65 ve 90 derece açıları daha büyük, 115 derecelik açıyı daha küçük tahmin etmektedirler.

Anahtar Kelimeler: Açı algısı, Autostereoskopik Ekran, Görsel İpucu, Derinlik Algis1 
To my father... 


\section{ACKNOWLEDGMENTS}

I wish to offer my sincere thanks and appreciation to my supervisor Prof. Dr. Yasemin YARDIMCI ÇETIN for her precious help, invaluable suggestions, continuous support, guidance, criticisms, encouragements and patience throughout this study.

I would like to also express my special gratitude to Yasemin Çetin for her support and suggestions throughout my research.

I am very grateful to Çağaçan Değer, Erdal Yılmaz, Fatih Ömrüuzun, Işıl Kıran, Murat Güneş, Anna Lozovska and Hüseyin Bulut for their support during various phases of this research from the preparation of experimental design to the editing of the thesis draft.

I would also like to thank my friends Kadri Y1lmaz, Haluk Terzioğlu, Saltuk Tanfer, Mahir Kaya, Nurcan Alkış, Ahmet Coşkunçay, and other colleagues for their friendship and encouragement.

I appreciate Ayşe Ceylan, Sibel Gülnar, Necla Işıklar, Çetin İnci, Ali Kantar and Yaşar Sayın of the institute for their kindness since the beginning of my M.Sc. study.

I would also like to thank to TÜBİTAK-BİDEB for financial support during my M.Sc education.

I would like to express my deepest gratitude to my mother, my mother in law, my father in law, my brother and my sisters for their love, encouragement, and support throughout my education.

Finally, I would like to take this opportunity to express my sincere thanks to my love Güler and my daughter, who is not yet born, for their heartfelt support and incredible patience while I was preparing this study. 


\section{TABLE OF CONTENTS}

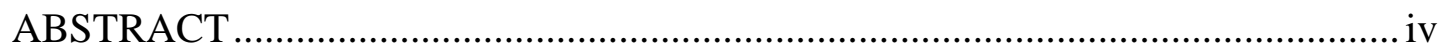

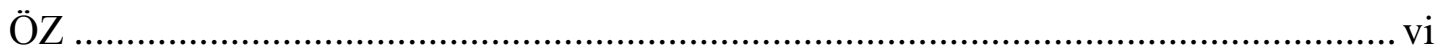

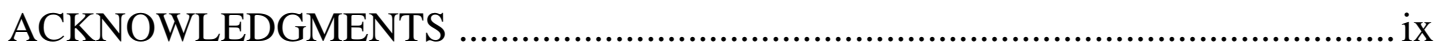

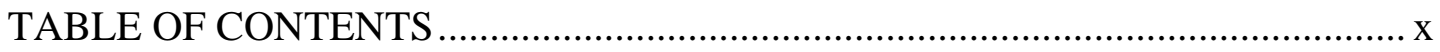

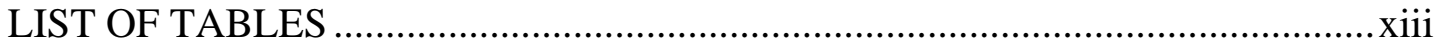

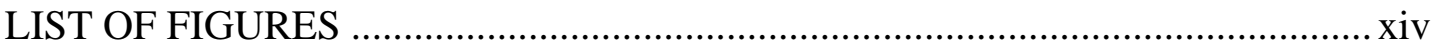

CHAPTER

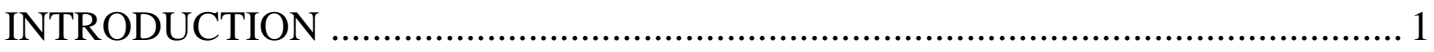

$1.1 \quad$ Problem Statement and Motivation ........................................................... 1

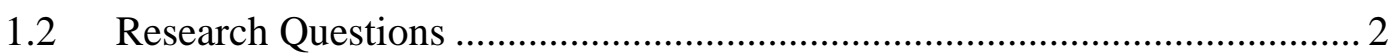

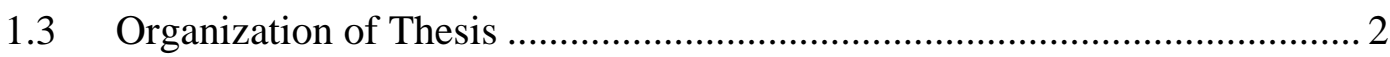

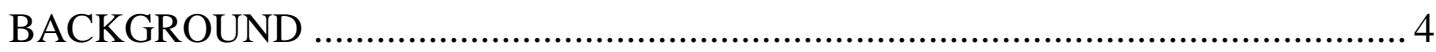

2.1.1 Types of autostereoscopic Displays ................................................. 5

2.1.2 Principle of Autostereoscopic Display................................................ 5

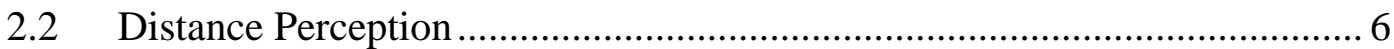

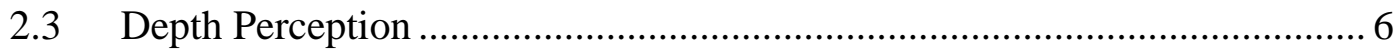

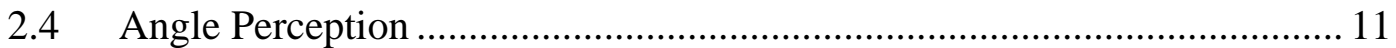

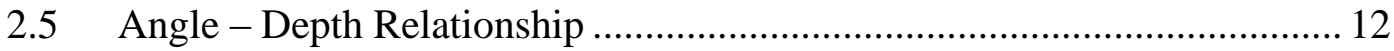

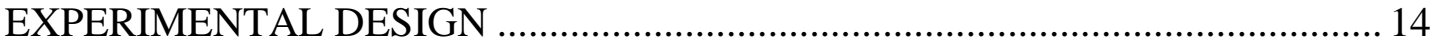

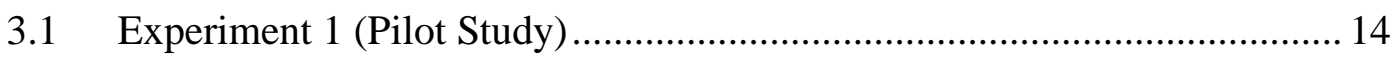




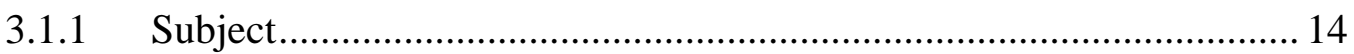

3.1.2 Location ................................................................................ 14

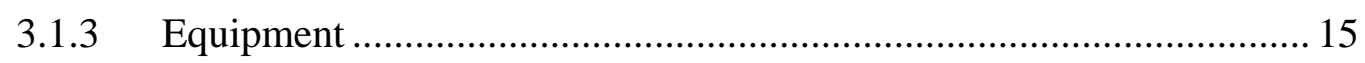

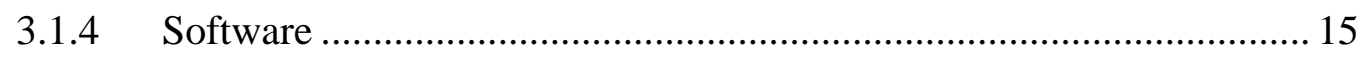

3.1.5 Procedure …............................................................................. 15

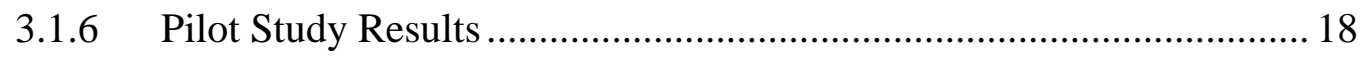

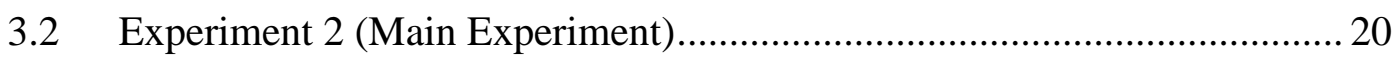

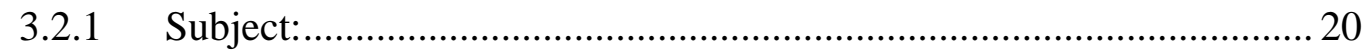

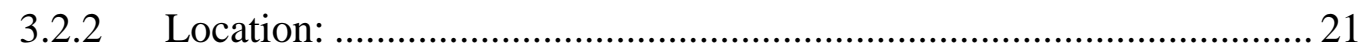

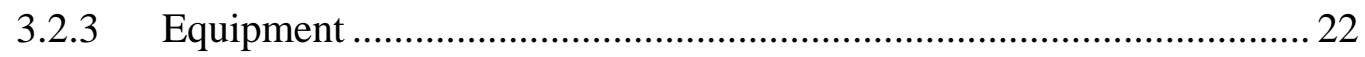

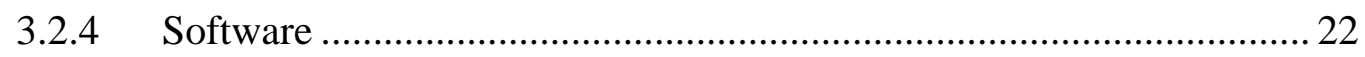

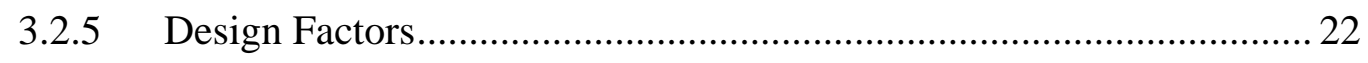

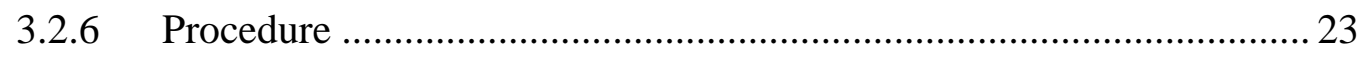

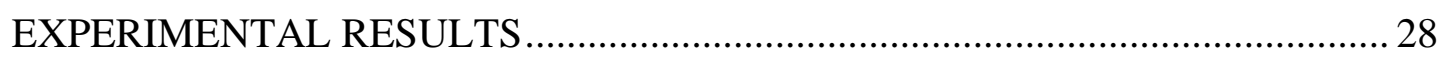

4.1 Learning Effect for Angle Estimation .................................................. 28

4.2 Comparing Angle Estimation Accuracy............................................... 29

4.3 Comparing Angle Measurement Accuracy .............................................. 33

4.4 Overestimation and Underestimation Analysis ..................................... 40

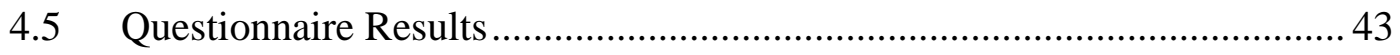

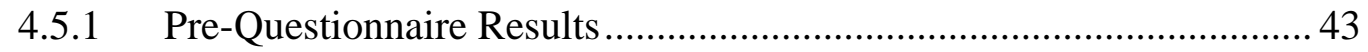

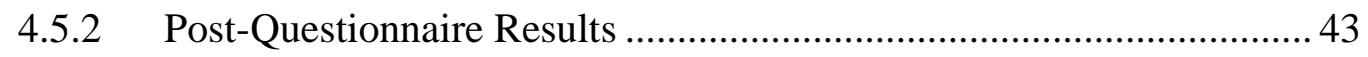

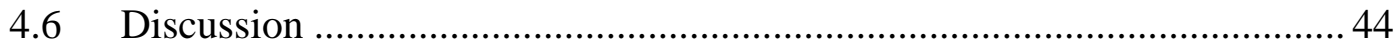

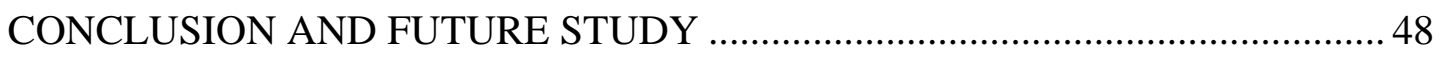

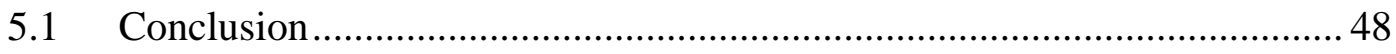




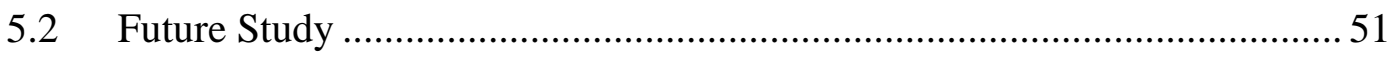

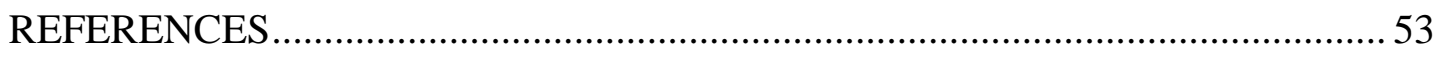

APPENDICIES

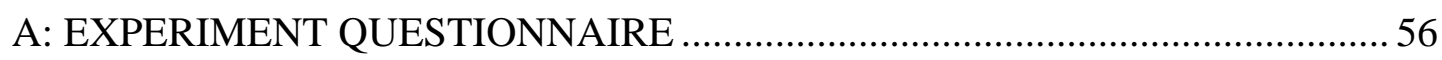

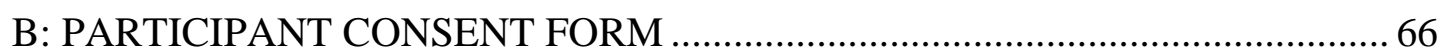

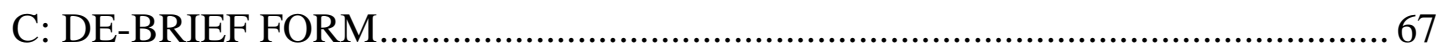

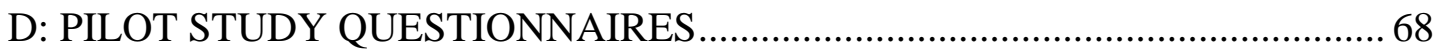

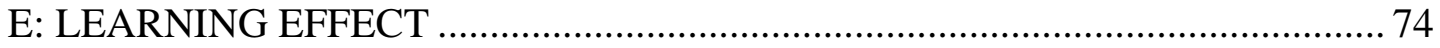

F: GENERAL VIEW OF EXPERIMENT RESULT ......................................... 75

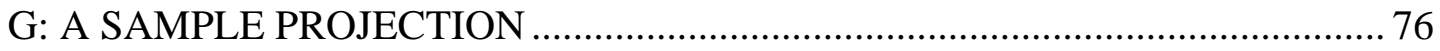

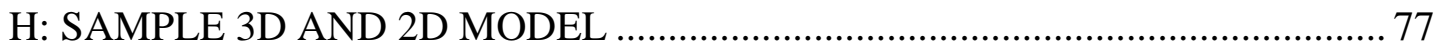

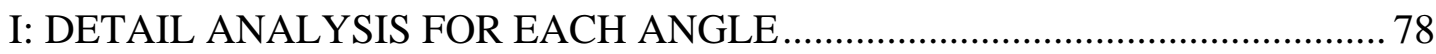




\section{LIST OF TABLES}

\section{TABLE}

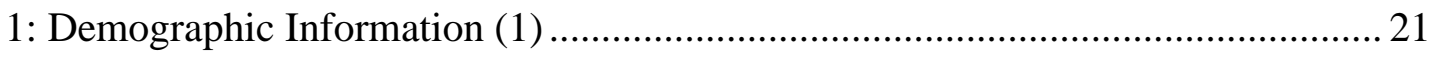

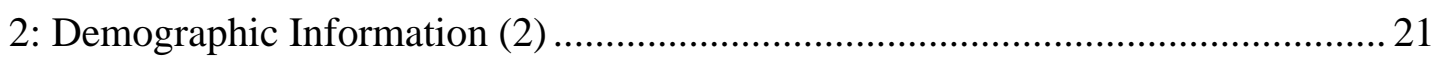

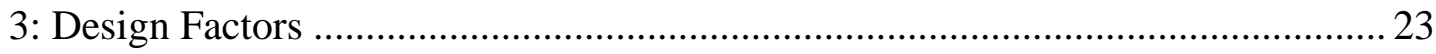

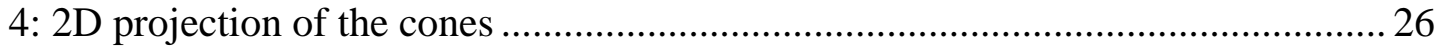




\section{LIST OF FIGURES}

\section{FIGURE}

1: Representation of viewing windows in autostereoscopic displays ........................ 6

2: Ntuen et al (2008), experiment scene for performance comparison...................... 8

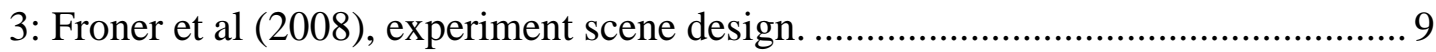

4: Grossman et al, 2006, Experiment Design.......................................................... 10

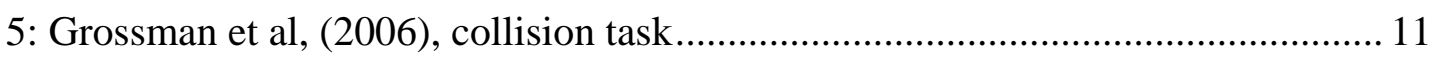

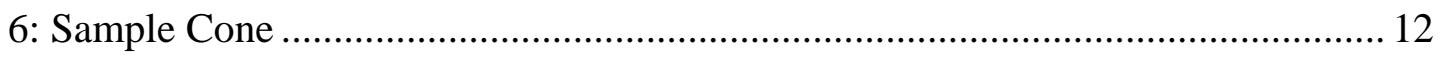

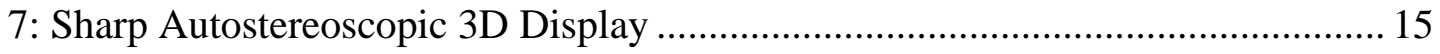

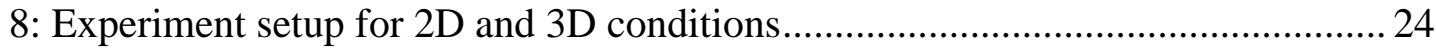

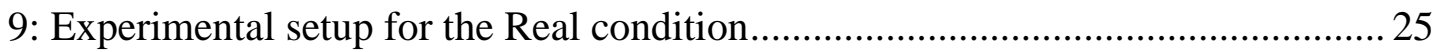

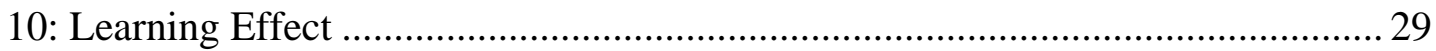

11 Estimation of Accuracy among 2D, 3D and Real Condition ................................ 30

12: Estimation Accuracy between 3D and 2D (35, 65, 115 degree) ......................... 32

13: Measurement Accuracy between 2D and 3D condition..................................... 34

14: Measurement Accuracy between 2D and 3D (35, 65 and 115 Degree)............... 35

15: Estimation vs Measurement for 2D condition ................................................. 36

16: Estimation vs Measurement for 3D condition …................................................ 37

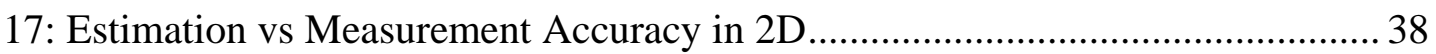

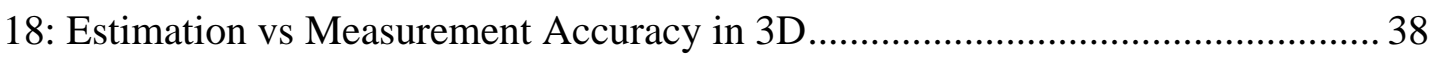

19: Estimation and Measurement Accuracy between 2D and 3D (Top View).......... 39

20: Estimation and Measurement Accuracy between 2D and 3D (Diagonal View).. 40

21: Estimation Accuracy (One Way Difference) ..................................................... 41 
22: Measurement Accuracy (One Way Difference)................................................... 42

23: Misperception of the Angles (Absolute Difference)........................................... 45

24: Misperception of the Angles (One Way Difference) …....................................... 46

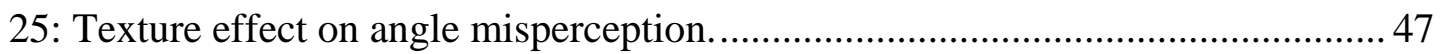

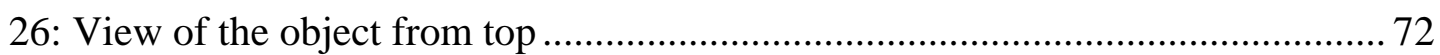

27: View of the object from a height of $100 \mathrm{~m}$. and tilted at an angle of 15 degrees to

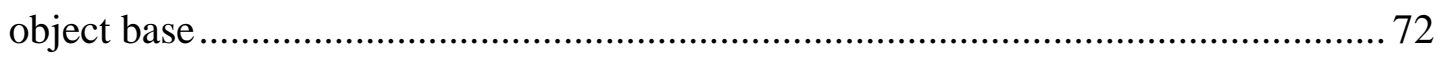

28: View of the object from a height of $45 \mathrm{~m} . \mathrm{s}$ and tilted at an angle of 60 degrees to

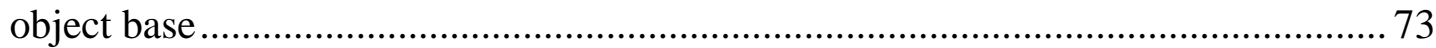

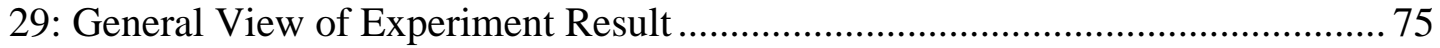

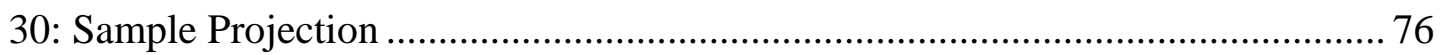

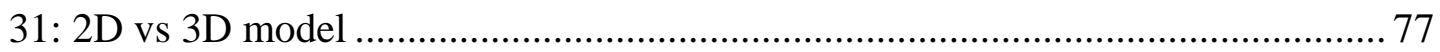

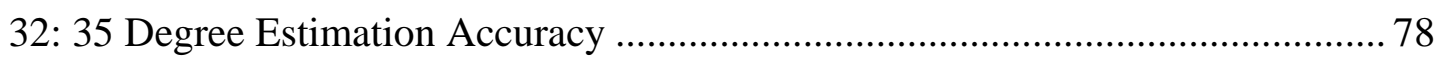

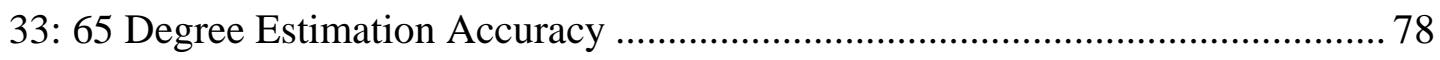

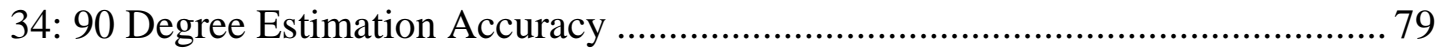

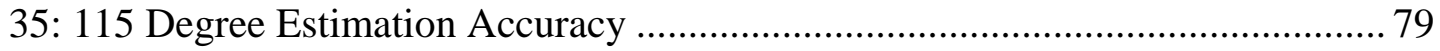

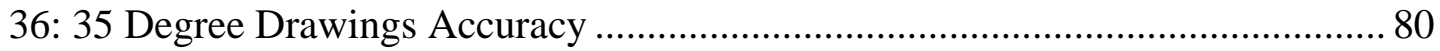

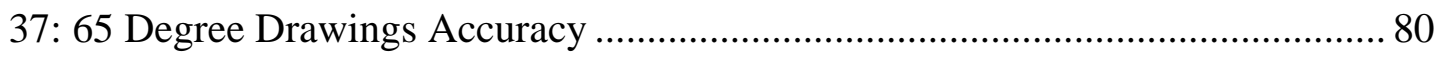

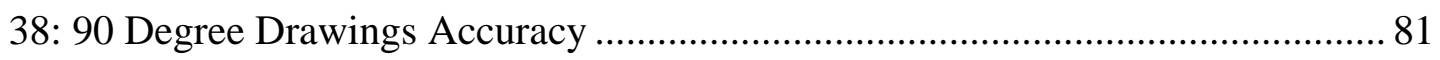

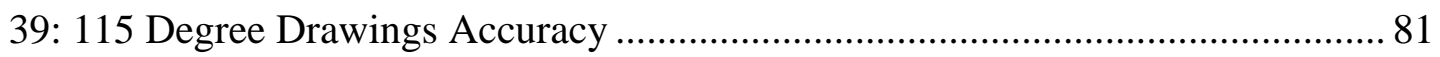




\section{CHAPTER 1}

\section{INTRODUCTION}

\subsection{Problem Statement and Motivation}

Development of multimedia applications has been growing exponentially in a wide range of fields from education to advertising, demanding improvements in display technology. 3D stereoscopic displays are examples of these technologies. Until recent years, stereoscopic images could be viewed with the help of some additional equipment such as special glasses and head gears. However, autostereoscopic displays provide opportunity for users to perceive 3D images without help of such equipment.

Today, people use display technology in many fields. The main problem of these technologies is to provide more realistic vision and more immersive environment to the user. Autostereoscopic display technology along with 3D TV and holograms are examples for the attempt to meet the realistic vision requests. With this technology, people don't have to use additional equipment to perceive 3D vision. Comparing to the other 3D technologies, autostereoscopic 3D displays can be used easily since their working principle is easy and they can be used with the naked eye. 
Cost, versatility, suitability and effectiveness are the factors to take in to account when deciding whether it is feasible to use autostereoscopic 3D displays in some applications such as simulators, games and TVs.

2 million 3D display units were shipped in 2003, and by 2010 this number will have quadrupled to reach 8.1 million units. These projections suggest that $3 \mathrm{D}$ displays may soon become a common part of everyday life and could significantly impact on how we view and interact with new media content (Alpaslan et al., 2005).

Significant amount of research has been done to investigate the perception differences of images on autostereoscopic displays. Yet most of these studies could not justify the need for such displays. These will be summarized in Chapter 2

\subsection{Research Questions}

In this study, mainly angle perception on autostereoscopic displays is investigated. For this investigation a pilot study and an experiment were conducted. In addition, depth and distance perception are also measured indirectly. The conic shapes' angles were varied while the user is viewing the objects from the top and diagonally.

This thesis focuses on the following questions:

- Do the autostereoscopic 3D displays increase angle perception compared to 2D displays?

- How does the angle perception differ in Real and virtual environments?

- Do angle estimation and measurement of drawings of perceived angles differ in terms of accuracy?

\subsection{Organization of Thesis}

This thesis is composed of five chapters. The first chapter includes introduction, problem statement and research question parts. 
We dedicated Chapter 2 to background information. In the second chapter, history of the autostereoscopic displays and their working principle are given. Moreover, notions of distance, depth and angle perception will be provided. How these notions are measured in virtual reality is another issue covered in the second chapter.

In Chapter 3, we provide the framework of the experiment. Description of hardware and software components, methods used in the experiment and autostereoscopic display implementation are presented. The major findings of this thesis are given in Chapter 4.

Finally, conclusions drawn from the experimental process and possible future directions for research are discussed in Chapter 5. 


\section{CHAPTER 2}

\section{BACKGROUND}

This chapter is composed of the following four sections: a general background on autostereoscopic displays, distance perception, depth perception and angle perception.

Autostereoscopic displays provide 3D stereo view experience without the help of any additional equipment. According to the Halle, (1997), autostereoscopic 3D displays present a three-dimensional image to a viewer without the need for glasses or other encumbering viewing aids. Dodgson, (2005) defines autostereoscopic displays as ones that provide 3D perception without the need for special glasses or other headgear. Other definitions one would encounter in the literature provide no new characteristics but emphasize that the viewer experience 3D perception without additional aids or gears.

Humans receive three-dimensional information from a variety of cues. Two of the most important ones are binocular parallax, scientifically studied by Wheatstone in 1838, and motion parallax, described by Helmholtz in 1866. Binocular parallax refers to seeing a different image of the same object with each eye, whereas motion parallax refers to seeing different images of an object by moving the head. 
Wheatstone was able to scientifically prove the link between parallax and depth perception using a stereoscope; the world's first three-dimensional display device (Matusik et al., 2004).

Autostereoscopic displays are the point that the technology has ultimately reached and they enable user to get stereo vision without any additional equipment.

\subsubsection{Types of autostereoscopic Displays}

There are three types of autostereoscopic displays: Two-view displays, two view head-tracked displays and multiview displays. In the case of the two-view display, images are visible in a single zone in space. If the viewer stands at the ideal distance and in the correct position he or she will perceive a stereoscopic image. In two view head-tracked displays, the position of the viewer's head and eyes are tracked and the appropriate images, left and right, could be displayed to the appropriate zones, thus preventing pseudoscopic viewing. In multiview displays viewers perceive a 3D image when both of their eyes are anywhere within the viewing zone (Dodgson N.A, 2005).

\subsubsection{Principle of Autostereoscopic Display}

In real world, when we look at an image or a scene, we see different images with each eye and similarly we see different images when we move our heads. So we can get potentially an infinite number of different images. When these two images are combined in the brain, we see the environment in 3D.

The same principle is in effect for autostereoscopic displays. Polti (2006) stated that, autostereoscopic 3D displays produce at least two pupils or windows at a region in space. If an observer places the right eye in one window, and left eye in another, each eye sees a different image on the display. The images constitute a stereo pair, and then a $3 \mathrm{D}$ image is seen, without the need to wear glasses. 


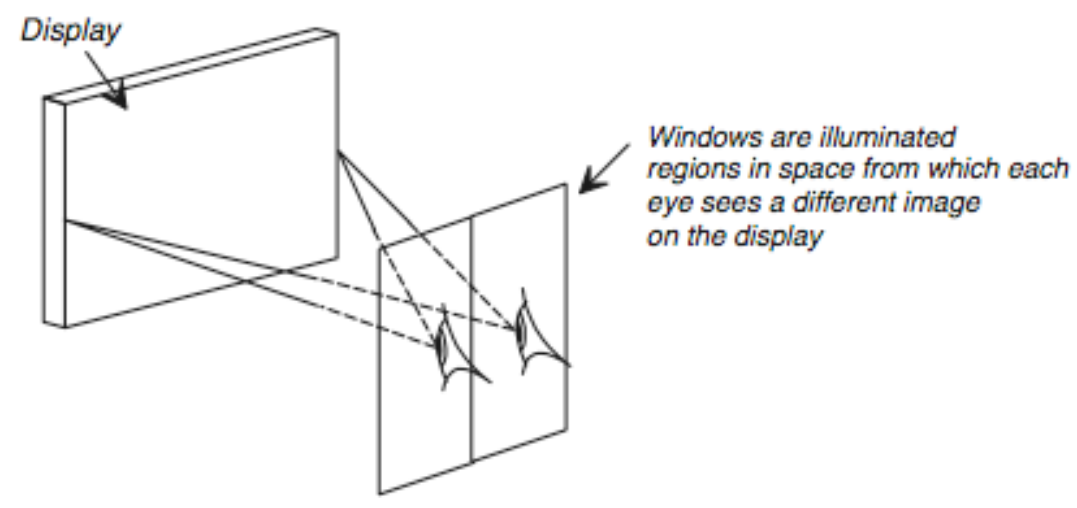

Figure 1: Representation of viewing windows in autostereoscopic displays

\subsection{Distance Perception}

Tasks such as throwing a ball at a target or steering a bike around an obstacle require that observers accurately perceive how far away objects are from them. Given the importance of distance perception for human action, it is critical to assess how well the distance perception of the real environment corresponds to the virtual one as stated by Plumert et al. (2005). Many researchers assess distance perception in a virtual environment with different methods. Bisection and blind walking can be used to assess distance perception. In the study by Rambli et al (2006), subjects are asked to estimate distances in horizontal, vertical and transverse distances with different size of displays and to write their estimation. Distance estimation in small displays is more accurate even though it causes underestimation of distances presented in the screen.

The other variable about distance perception may be the environment. Meng et al (2006) found that there are no perception differences whether distance estimation is made on an indoor hall way image or an outdoor image.

\subsection{Depth Perception}

In Oxford dictionary, 'depth' is defined as the distance from the top to down, from the surface to inwards, or from front to back. We can define 'depth perception' as the 
visual ability to see the world in three dimensions. People perceive depth with the help of some visual cues.

We can classify depth cues under two groups; monocular and binocular depth cues. Monocular depth cues are perspective, size, interposition and lighting and shadow. Binocular ones are convergence, binocular disparity and motion parallax (Çetin, 2008).

People can perceive $3 \mathrm{D}$ structure of objects on $2 \mathrm{D}$ projections with the help of perceptual cues (Dodgson, 2005). These cues are;

Occlusion : One object partially covering another. It is also known as interposition cues. Closer object can block the distant one.

Perspective : Perspective is a depth cue from different viewpoints in which objects appear different (Foresell, 2007).

Familiar size : We know the real-world sizes of many objects and we can compare unknown objects with known objects on scene in terms of size (Bigham 2005).

Atmospheric haze: Objects further away look more washed out.

These cues enable people to make sense of photographs and images on a television screen, at the cinema, or on a computer monitor. However, some cues are missing in two dimensional media. These cues are;

Stereo parallax $\quad$ : Seeing a different image with each eye.

Movement parallax : Seeing different images when we move our heads.

Accommodation : The eyes' lenses focus on the object of interest.

Convergence $\quad$ : Both eyes converge on the object of interest.

Dodgson (2005) also states that all stereoscopic displays provide at least stereo parallax cue. 
After the definition and cues of the depth perception, we need to explore how depth perception tasks are carried out in perception experiments. In virtual environments, depth perception experiments vary according to the researcher and devices used. In the study carried out by Ntuen et al. (2008), two experiments were conducted to assesss differences between 2-D and 3-D modes on an autostereoscopic display. Sharp PC-AL3DU was used in their experiments. The first experiment is related to the depth perception performance. Sixteen students participated in their experiment. They used a chin rest to ensure that participant viewed the screen from the correct distance and with the specified angle. The scene of the experiment is depicted in Figure 2. The participant had to decide which ball is closest to the cone. Each scene includes one cone and three different color balls. The objects were prepared by using Google Sketch Up and presented by using Google Earth software. According to this experiment result, the depth perception was not significantly enhanced using a 3-D display.

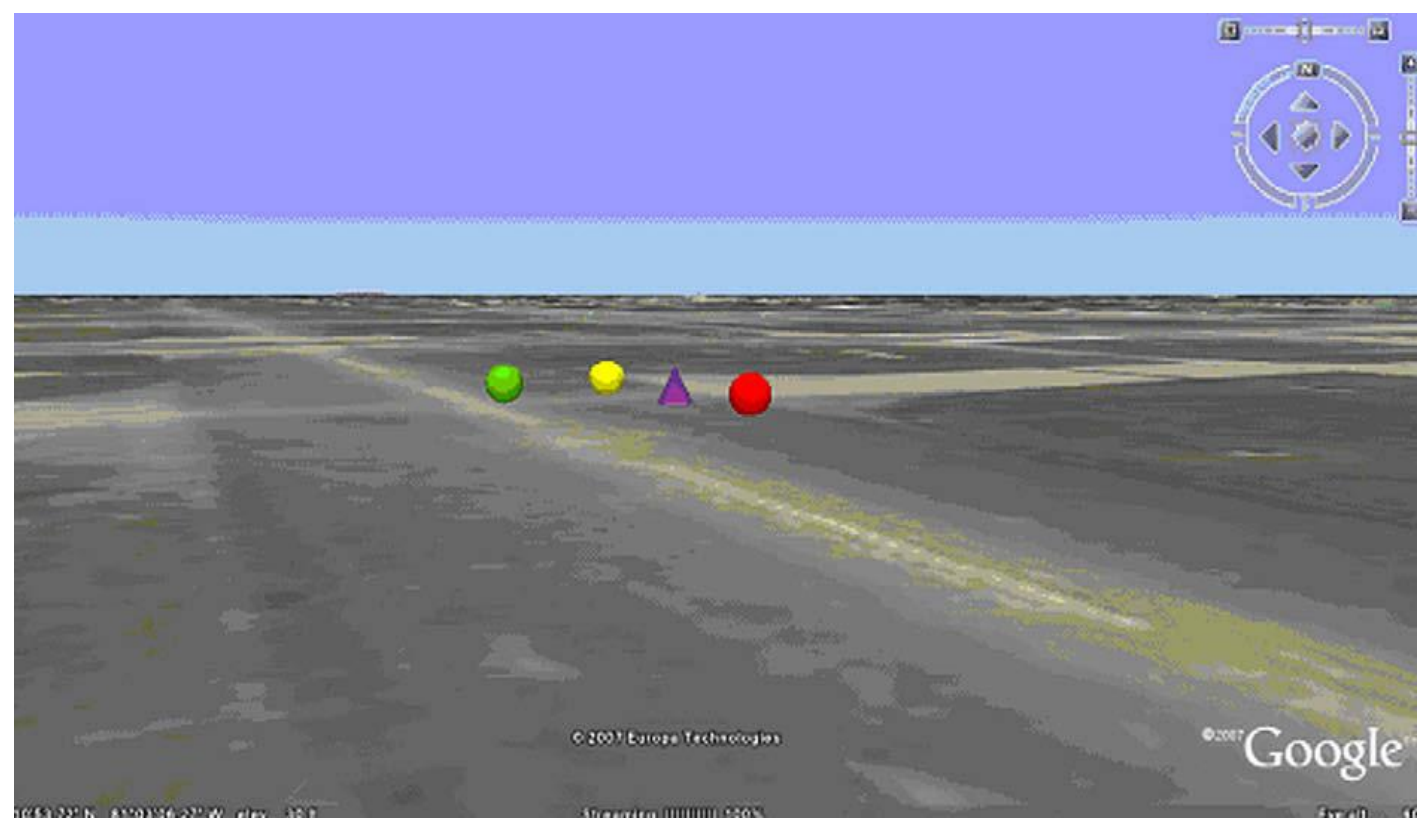

Figure 2: Ntuen et al (2008), experiment scene for performance comparison. 
Another study about depth perception assessment was conducted by Froner et al (2008). The aim of the study is to quantify and understand inter-display depth perception differences providing performance information for end-users and display system designers. They conducted an experiment for this aim. Fourteen subjects participated in the experiment. The scene of the experiment consists of two white squares on a black background. The horizontally positioned squares were centered in the middle of the screen. There was a small square for fixation point which has 6 pixel widths. Participants were asked to maintain fixation on this point as they were performing the task. The distance between the two great white squares was 30 pixels. In Figure 3, the demonstrative presentation of the experiment scene is shown. They changed viewing distance of the participants according to the 3D display. In each trial one square was always positioned on the display plane while the position of other square was randomly chosen among the four disparity levels; $0,1,2$ and 3 pixels.

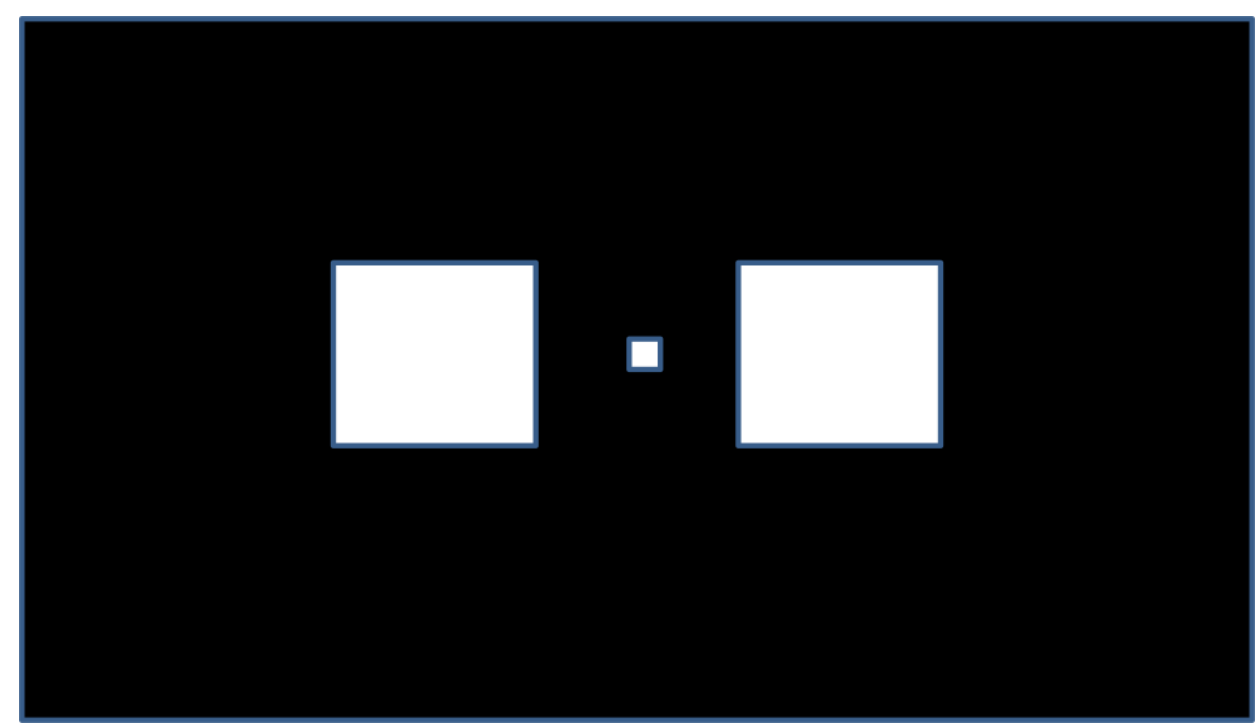

Figure 3: Froner et al (2008), experiment scene design.

Participants were asked to determine which square is closest to them for each trial and they answered the question by using keyboard. When they couldn't decide, they were requested to guess. According to the result, participants' performance was good 
in general. As this study is the comparison of the seven different 3D displays we cannot mention comparison with 2D. However, the result shows us that participants' performance was high on Sharp 3D autostereoscopic display.

The other method for assessment for depth perception performance was used in the study conducted by IJsselsteijn et al (2000). In this study, they used two images and eighteen parameters. They use a 20 inch stereoscopic display. As an experimental task, they asked the participant to rate quality and naturalness of images from 1 to 10 . Since the aim of the IJsselsteijn et al (2000) is to investigate effects of stereoscopic film parameters and display duration, the findings are not relevant to our study.

In the study by Grossman et al (2006), two tasks were used for depth perception assessment. The aim of the study is to compare volumetric displays to other $3 \mathrm{D}$ display techniques with regard to user ability to perceive depth information when viewing 3D imagery. For our study we pay special attention to the tasks used in their experiment. There are two tasks related to depth perception. The first task includes asking participant to rank the depth of a sphere which was floating above the floor in a 3D graphical scene. The scene design is shown in Figure 4. Participants were allowed to rank the sphere after a three second view of the scene by using keyboard.

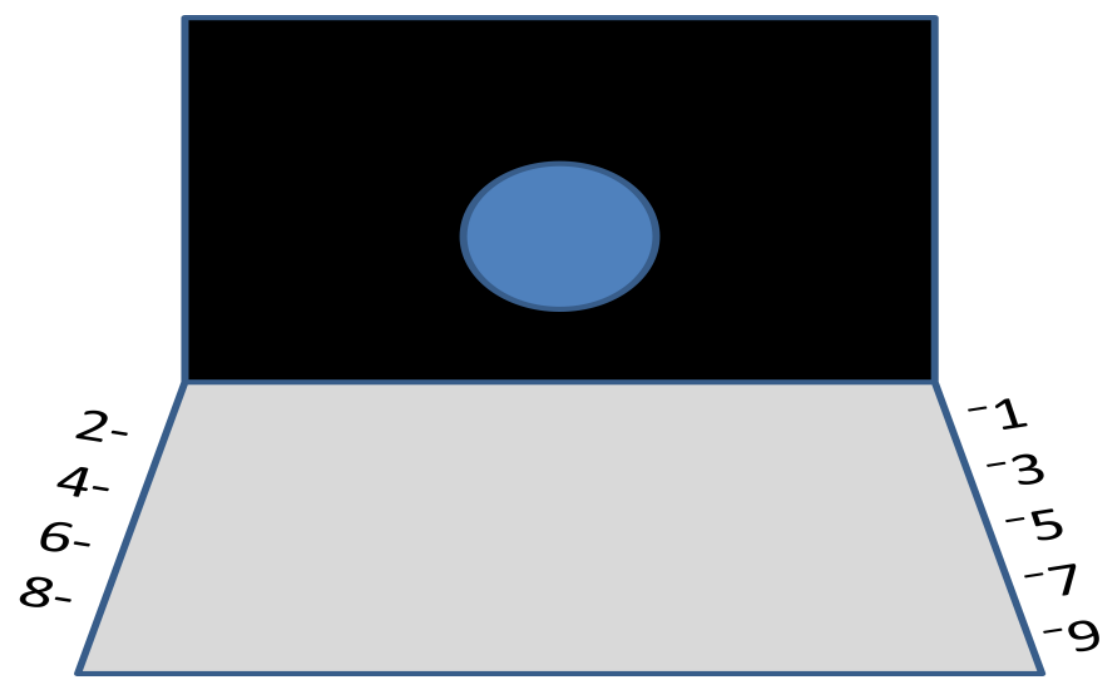

Figure 4: Grossman et al, 2006, experiment design 
In the second task, participants were asked to make spatial judgments about a dynamic 3D scene. In the scene, there were two objects that were flying towards each other and disappeared before reaching a potential point of impact, and participants determined whether or not the objects were going to collide. The scene design is shown in Figure 5.

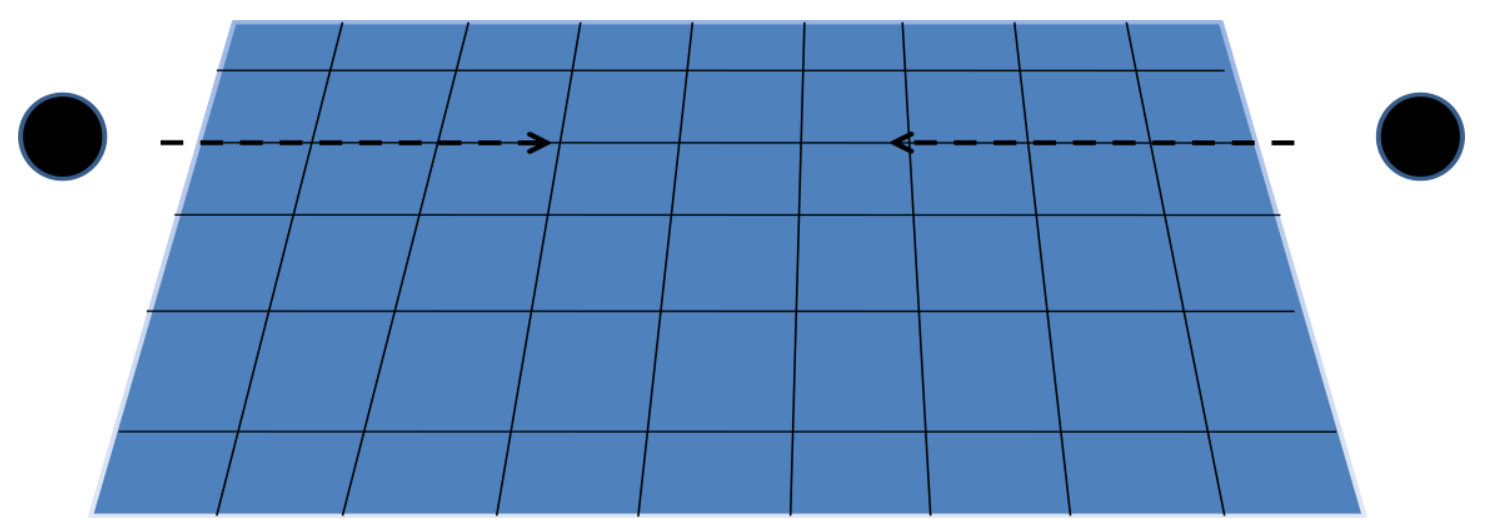

Figure 5: Grossman et al, (2006), collision task

In order to apply this task, stereo or motion cues have to be provided in the environment. Otherwise, the task is impossible.

The study concludes that volumetric display provides more depth information than stereoscopic display with a head tracking setup.

\subsection{Angle Perception}

Angle is the difference in direction between two lines or surfaces. Angles are measured in degrees and they are classified basically in to three types; acute, right and obtuse angle. There are many studies in terms of angle perception. However, the basic findings of those studies are almost the same. For example, Nundy et al. (2000) claim that Wundt (1897) states, in terms of perception, that observers tend to overestimate the magnitude of acute angles and underestimate obtuse ones. Another study by Carpenter and Blakemore (1972) states that "Single lines cause changes in the apparent orientation of nearby lines of somewhat different orientation: acute 
angles are perceptually expanded while obtuse angles apparently contract." These findings were also confirmed by Fisher (1969), Heywood and Chessell (1977), Greene (1994),Williams et al. (1998), Lotto et al. (1999) and Purves et al. (1999).

Until recent years, this misperception is thought as a result of geometrical distortions. However, recent studies show that, this misperception takes its source from empirical strategy that resolves the inherent ambiguity of angular stimuli by generating percepts of the past significance of the stimulus rather than the geometry of its retinal projection (Nundy et al, 2000).

\subsection{Angle - Depth Relationship}

In Oxford dictionary, 'depth' is defined as the distance from the top down, from the surface inwards, or from front to back. In other words, depth is not only the distance from front to back but it is also the distance from top to down. On the other hand, angle is the difference in direction between two lines or surfaces. We can combine these two concepts in cone objects. Cones have a distance from top to down and they also have angle information. When we look at a cone totally above, we can see the distance from top to down. This is the depth information. Moreover, the more accurate an observer gets the vertex angle of the cone form the top view, the more accurate depth s/he gets. In the Figure 6 we can see the sample cone.

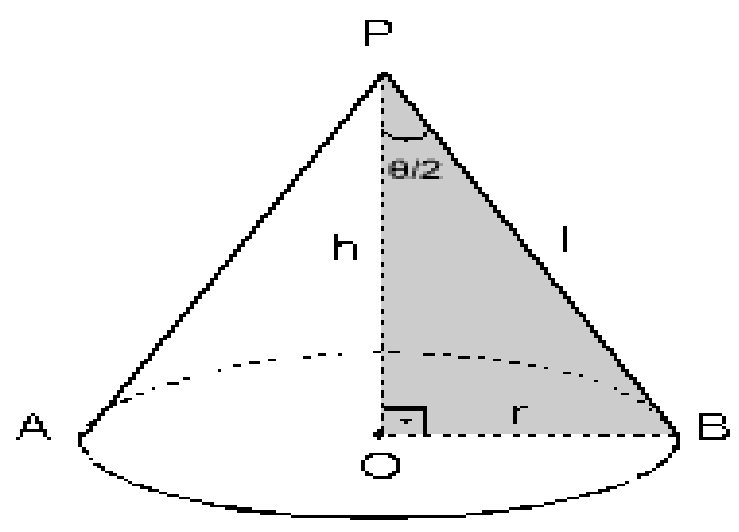

Figure 6: Sample Cone 
The " $h$ " value is the height and " $r$ " is the radius and "l" is the hypotenuse of the cone. We can calculate the vertex angle of the cone like;

$\operatorname{Vertex}\left(\right.$ Top)Angle $\theta=2 * \arctan \frac{r}{h} \quad$ Equation 1

When an observer looks at the cone from above he infer the depth information, which is the distance from top to down. The depth is the " $\mathrm{h}$ " value. According to the Equation 1 stated above, the greater the observer perceives vertex angle, the smaller "h" value (depth) s/he perceives. 


\section{CHAPTER 3}

\section{EXPERIMENTAL DESIGN}

In our study, two experiments were conducted to compare angle perception on 2D and autostereoscopic 3D displays. The first experiment was conducted as a pilot study. This chapter includes design, software, hardware, design factors and procedures of those two experiments.

\subsection{Experiment 1 (Pilot Study)}

\subsubsection{Subject}

A total of 30 people, 19 male and 11 female, have participated in this study. They were between 23 and 46 years of age with a mean age of 23 and median of 26 . Of these 30 people 4 are undergraduates, 14 are master students, and 10 are $\mathrm{PhD}$ students whereas 2 have received their $\mathrm{PhD}$ degrees. 14 of the participants had previous experience with 3D displays. All participants had either normal or corrected vision.

\subsubsection{Location}

The pilot study was conducted in a study hall at METU Informatics Institute in 2008/2009 fall semester. The hall includes fourteen desks and there is a bookcase for 
each. The dimensions of the hall are $15 \mathrm{~m}$ length and $7 \mathrm{~m}$ width. The experiment was conducted on the left corner of the hall located far from the entrance.

\subsubsection{Equipment}

In the experiment, a Sharp PC-AL3D laptop was used. The resolution of the laptop was $1024 \times 768$ on 15 " display size. The laptop has a switch button used to switch between $3 \mathrm{D}$ and $2 \mathrm{D}$ modes.

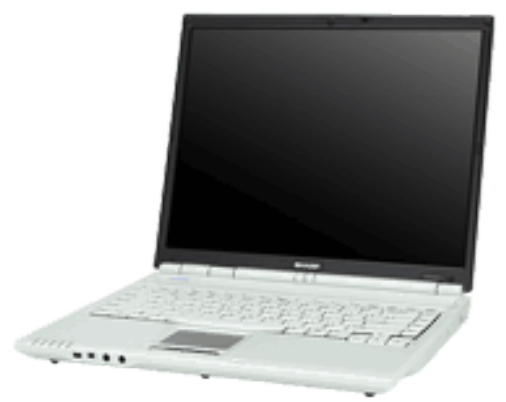

Figure 7: Sharp Autostereoscopic 3D Display

\subsubsection{Software}

Operating system of the laptop is Windows XP professional with service pack 2. In the pilot study two main tasks were conducted. The first task, the subjects were shown 24 images on the laptop computer. In order to render these images, TriDef photo viewer was used. In the second task, 3D models of two buildings created in Google Sketch Up were used. To show these models TriDef's visualizer for Google Earth were used. These applications licenses were OEM license. They are coherent for the display device.

\subsubsection{Procedure}

Experiment sequence is as follows

1. Gathering demographic information about participant.

2. Asking participants to estimate two real distances in the room 
3. Viewing stereo images to familiarize the participant with the display and find the sweet spot.

4. Evaluating 24 stereo images from worst (1) to best (5).

5. Asking the estimate of vertex (top angle) angle of the top view of conic shape

6. Asking the participants to draw the shape's profile by assuming that it is the projection of a 3D object.

7. Asking the participants to estimate height and width of the object

8. Asking the participants to estimate the distance between the walls in shown image.

9. Posting test questions

Questionnaires are also presented in Appendix D.

\section{Pre-Test}

Initially, a pilot study was conducted with five participants in order to arrange tasks, materials, quality of questions and environmental conditions of the test hall. After this pilot study, actual experiment setup was formed. When the participants arrived at the study hall, s/he was informed about the purpose of the study and completion time, and then s/he was asked to sit in front of the laptop. Before starting the experiment, pre-questionnaire (see Appendix D) was completed by the participant. By polling this questionnaire, researcher tried to get an opinion about distance perception of participant and whether s/he strategizes the task of estimation. That is, they were asked to estimate the distances of the far wall and close wall of the test hall. Next, a slideshow was shown to the participant and the participant was asked to find the "sweet-spot", the point that the user gets the best stereo view, as quickly as possible. The time was noted by researcher. Then the same slideshow composed of 24 autostereoscopic images was started again, and the participants were asked to evaluate these images in terms of 3D stereo perception. S/he scored each image from one (worst) to five (best). This scaling was recorded by researcher so that the participant does not lose the sweet spot. 


\section{Main Experiment}

The second task includes angle, depth and distance perception. The participant was shown an image which includes head of a tower (spire) created via Google Sketch Up with the correct rate of dimensions on Google Earth application on 2D mode. The image is the model of Galata Kulesi which is 66 meters tall and has a radius of 13 meters. The image is viewed directly from above (Appendix D). The participant was asked to guess what the image looks like and define whether it is a concave or a convex shape. S/he was also asked to draw the profile of the image by assuming that the image is the projection of a 3D object. And s/he was asked to estimate the vertex of the conic shape. The sketched shapes' angle was measured to compare with the estimated values. Then the mode of the laptop was changed over to $3 \mathrm{D}$, and the same questions were asked again. For not everyone may be familiar with the concepts, a printed material describing projection and profile was provided to subjects. Then the viewing angle of the image is changed to 15 degrees tilt angle and viewing distance from the ground is increased to 100 meter (Appendix D). The next question addressed to the participant is to estimate the length and radius of the model. In order to understand whether the participant used past information in the estimation, s/he asked past experience about the model; that is, the subject is asked whether s/he has seen the model in real life before.

Then another 3D Google Sketch Up model was shown and the participant was asked to estimate the distance of two walls as can be seen in Appendix D. This question is asked to the participant in either 3D or 2D mode. While whether a participant is subject to $2 \mathrm{D}$ or $3 \mathrm{D}$ is random, total number of participants subject to either case is equal at 15. All estimations were to be made in meter. With this step the task was completed. After the experiment, post-questionnaire was conducted in order to understand quality of 3D models, stereo comforts of the autostereoscopic device and the strategy the participant uses during distance estimation on virtual environments. The experiment took 24 minutes on average. 


\subsubsection{Pilot Study Results}

\section{Angle perception differences between 3D and 2D displays:}

In order to measure differences between $2 \mathrm{D}$ and $3 \mathrm{D}$ condition, we should apply a paired T-Test. Before conducting the test, it was realized that there were three outliers. The outliers were eliminated and the normality test was applied. According to the result of Kolmogorov-Smirnov test, 2DAngle, $(D(27)=0.235, p<0.05)$, and 3D Angle, $(\mathrm{D}(27)=0.201, \mathrm{p}<0.05)$ were both significantly non-normal. That is the data is not normally distributed, so we should conduct a non-parametric test. For the same subject under two different conditions, we conducted Wilcoxon Signed Ranks Test. As a result of the test we can report that; for 3D display $(\mathrm{Mdn}=90)$; angle estimation is more accurate than $2 \mathrm{D}$ display $(\mathrm{Mdn}=115), \mathrm{T}=19, \mathrm{p}<.05, \mathrm{r}=-.47$. This is the medium to large effect. That is, on 3D displays, users get more accurate angle information and they can make more accurate estimation.

This result shows us that, on autostereoscopic display, subjects may get more realistic perception than traditional 2D display.

\section{Estimating error differences between 2D and 3D displays}

Differences between the estimated and measured angles drawn by the participants during the experiment are analyzed to find if there is a statistically significant difference between 2D and 3D conditions. First the normality of the data was checked. Kolmogorov-Smirnov revealed that 2DAngleError, $(D(30)=0.105, p>0.05)$, and 3D AngleError, $(\mathrm{D}(30)=0.95, \mathrm{p}>0.05)$ were both significantly normal data. Then, Paired Samples Test was applied to the data. The results showed that there is no statistically significant differences between the estimating error of 2DAngleError $(M$ $=-.33 ; S E=5.36)$ and 3DAngleError $(M=3.33, S E=5.30, \mathrm{t}(27)=-.511, p>.05)$.

The possible result of any estimation process may be in failure. We attempted to examine whether there is a statistically significant difference between estimation errors made on different display types. We may conclude that, the deviation between actual value and estimated value does not change according to the display type.

\section{Distance perception differences between 2D and 3D displays}


During the experiment, 15 subjects were asked to estimate 4 meters real distance between two walls on different display modes; 3D and 2D. In order to analyze the differences between these groups we should conduct independent t-test. For conducting this test normality and homogeneity assumptions should be assured. However; the normality assumption was not satisfied. The result shows that; 2D distance estimation error, $\mathrm{D}(15)=0.347, \mathrm{p}<0.05$, and $3 \mathrm{D}$ distance estimation error, $\mathrm{D}(15)=0.256, \mathrm{p}<0.05$ were both significantly non-normal. So, it is recommended to conduct a Mann-Whitney Test to explore differences between these groups. The one way distance estimation error of the subjects who asked to estimate on $2 \mathrm{D}$ display $(M d n=0.00)$ didn't seem to differ in one way distance estimation error from those of on 3D display $(M d n=0.00), U=88.00, \mathrm{~ns}, r=-0.26$.

This result shows us that, in terms of distance perception, autostereoscopic displays may not provide advantage against to $2 \mathrm{D}$ display.

\section{Angle perception differences between having normal vision and having corrected vision subjects}

In our sample, half of the participants have corrected vision, using glasses or other equipment, and other half have normal vision. In order to analyze the angle perception differences between these groups we should conduct independent t-test with its assumption. After conducting normality test we get the result of Kolmogorov-Smirnov test like; participants who have corrected vision, $\mathrm{D}(15)=0.347$, $\mathrm{p}>0.05$, was significantly normally distributed but participants who have normal vision, $\mathrm{D}(15)=0.264, \mathrm{p}<0.05$ was significantly non-normal. Then we tried to apply $\mathrm{Z}$ transformation to these data to make them normal. After transformation we get the result like; participants who have corrected vision, $D(15)=0.347, p>0.05$ and those of having normal vision $\mathrm{D}(15)=0.347, \mathrm{p}=0.05$, were both significantly normally distributed. Homogeneity test was also assured. As a result we can apply independent t-test to explore statistical differences. According to the test, on average corrected vision participants $(\mathrm{M}=74, \mathrm{SE}=14.93)$ made more accurate estimation than normal vision participants $(\mathrm{M}=76, \mathrm{SE}=17.19)$. But this difference is not significant $\mathrm{t}(28)=-0.088, \mathrm{p}>0.05$. 
Distance Perception differences between participants who saw the object used in experiment before in real life and who didn't see.

There were 13 participants who saw the object used in the experiment in real life, and 17 participants did not see the object before in real life. In order to explore whether there is a statistical difference between these groups in terms of distance perception, we tried to apply independent t-Test. However, normality assumptions were satisfied but homogeneity assumptions were not. Then we applied the two independent sample non -parametric test called Mann-Whitney Test. The distance estimation error of the subjects who saw the object (Galata Kulesi) (Mdn=6.00) in real life did not seem statistically differ in distance estimation accuracy from participants who did not see the object in real life $(M d n=6.00), U=107.00$, ns, $r=-$ 0.027 .

In conclusion, we may say that distance perception does not change with the conditions. However, angle perception difference between 2D and 3D is significantly different. That is, autostereoscopic display provides better angle perception. According to this pilot study result, we decided to conduct another experiment with conic shapes.

\subsection{Experiment 2 (Main Experiment)}

\subsubsection{Subject:}

A total of 40 people, 17 female and 23 male, have participated in this experiment. All participants had normal or corrected to normal vision. The participants were between 20 and 38 years of age with a mean age of 27, 6 and median of $27(\mathrm{SD}=3,16)$. Of these forty people, 5 are undergraduates, 15 are master and 20 are $\mathrm{PhD}$ students. In the Table 1 and Table 2, the summary of the subjects' information is given. No subjects that neither participated in the pilot study nor any colleague who know the research questions of the thesis were used in the main experiment. 
Table 1: Demographic Information (1)

\begin{tabular}{|lc|cc|cc|}
\multicolumn{2}{|c|}{ Gender } & \multicolumn{2}{c|}{ Age } & Normal & 23 \\
Male & 23 & Average & 27,6 & & \\
\hline Female & & & & & \\
& & Range & $20-38$ & Corrected & 17 \\
& & & & & \\
\hline & & SD & 3,16 & & \\
\hline
\end{tabular}

(a)

(b)

(c)

Table 2: Demographic Information (2)

\begin{tabular}{|c|c|c|c|c|c|}
\hline \multicolumn{2}{|c|}{ 3D Experience } & \multicolumn{2}{|c|}{$\begin{array}{l}\text { The Frequency of Playing } \\
\text { Computer Games }\end{array}$} & \multicolumn{2}{|c|}{ Education Level } \\
\hline Yes & 20 & Continuously & 6 & Undergraduate & 5 \\
\hline \multirow{2}{*}{\multicolumn{2}{|c|}{ No }} & $\begin{array}{l}\text { Once a week / } \\
\text { One a Month }\end{array}$ & 23 & Master & 15 \\
\hline & & Never & 11 & Doctorate & 20 \\
\hline & & & & (f) & \\
\hline
\end{tabular}

G-Power version 3.0.10 was used to calculate the total sample size. Since repeated measures ANOVA test is going to be applied for the analysis of the experiment and significance level is going to be $\alpha=0.05$, total sample size was calculated as 39 . This is why we conducted the experiment on 40 participants.

\subsubsection{Location:}

The experiment was carried out at METU Informatics Institute in July, 2009 in a 3m by $5 \mathrm{~m}$ room. 


\subsubsection{Equipment}

In the experiment, Sharp PC-AL3D laptop was used. The properties of the laptop is Intel Pentium M Processor $1.86 \mathrm{GHz}, 1 \mathrm{~GB}$ of RAM, Graphics adapter NVIDIA GeForce Go 6600 (128 MB), Display 15" TFT LCD (1024 x 768). Since Sharp AL3DU laptop has a button which is used to switch between 3D and 2D modes, it is suitable for the experiment because it enables fair comparison of $2 \mathrm{D}$ and $3 \mathrm{D}$ conditions.

For the Real condition tasks, we used four cones with different vertex angles. The first through the last cones have 35, 65, 90 and 115 degree vertex angles respectively. We wanted to keep the number of vertex angles as small as possible so that the subjects can complete the experiment in a reasonable time. To cover all angle ranges (acute, right and obtuse), we selected these angles. They are almost uniformly spaced yet are not familiar to the subjects as 30,60, 90 and 120 degrees are. All Real cones have $4 \mathrm{~cm}$ radius.

\subsubsection{Software}

Operating system of the laptop is Windows XP Professional with service pack 2. Before the main experiment, 24 demo autostereoscopic images were shown to the participants with the help of TriDef photo viewer software. For the main tasks, four different cones from two different perspectives were created in Google Sketch Up. They were shown to the participants with Google Earth software. These applications licenses were OEM license. Lastly, we built randomization software to make the order of the cone pictures different for each participant.

\subsubsection{Design Factors}

Design factors of this experiment were angle of cone, view point and condition. Design factors are summarized in Table 3. 
Table 3: Design Factors

\begin{tabular}{|l|l|l|}
\hline Design Factors & Level & Range \\
\hline Angle & 4 & $35,65,90$ and 115 degree \\
\hline View Point & 2 & $\begin{array}{l}\text { View from top and with 15 } \\
\text { degree tilt. }\end{array}$ \\
\hline Condition & 3 & $\begin{array}{l}\text { 2D display, 3D display and } \\
\text { Real Condition. }\end{array}$ \\
\hline
\end{tabular}

\subsubsection{Procedure}

There are four phases in the experiment. In the first phase, participants signed the consent form. The form informs the participants about the aim of the study and procedure of the experiment. Then, the participants were asked to fill in the prequestionnaire which includes demographic and experience information.

In the second phase, participants were offered a demo presentation in the autostereoscopic 3D display. The aim of this demonstration is to familiarize the participant with the display. This familiarization process took approximately two minutes. Then, participants were shown an image which includes a cone on Google Earth application. The cone is viewed directly from above. The participants were asked to guess what the image looked like and define whether it was a concave or a convex shape.

The third phase of the experiment includes three parts. In the first part, each participant was shown a cone on Google Earth software on 2D mode. S/he was asked to draw the profile of the image assuming that the object is the projection of a 3D model. Also s/he was asked to estimate the vertex of the conic shape. Totally eight cones are shown in the 2D mode. In each trial either the angle of the cone or the viewpoint was changed. The cones are shown in Table 4 . In the second part, the same process was repeated in the 3D mode. For not everyone may be familiar with the concepts, a printed material describing projection and profile were provided to participants (Appendix G). These two parts of the third phase were conducted in 
front of the table as shown in the Figure 8. The third part of this phase was similar to other parts. In this part participants were shown real cones and they were asked to estimate vertex (top) angle of the cone, and write the estimation in the form given before the experiment. Like in other parts, 4 Cones x 2 Perspectives object were shown. The main difference from other parts is that participants were not asked to draw the projection of the real cone. This third part was conducted in front of a board as shown in Figure 9.

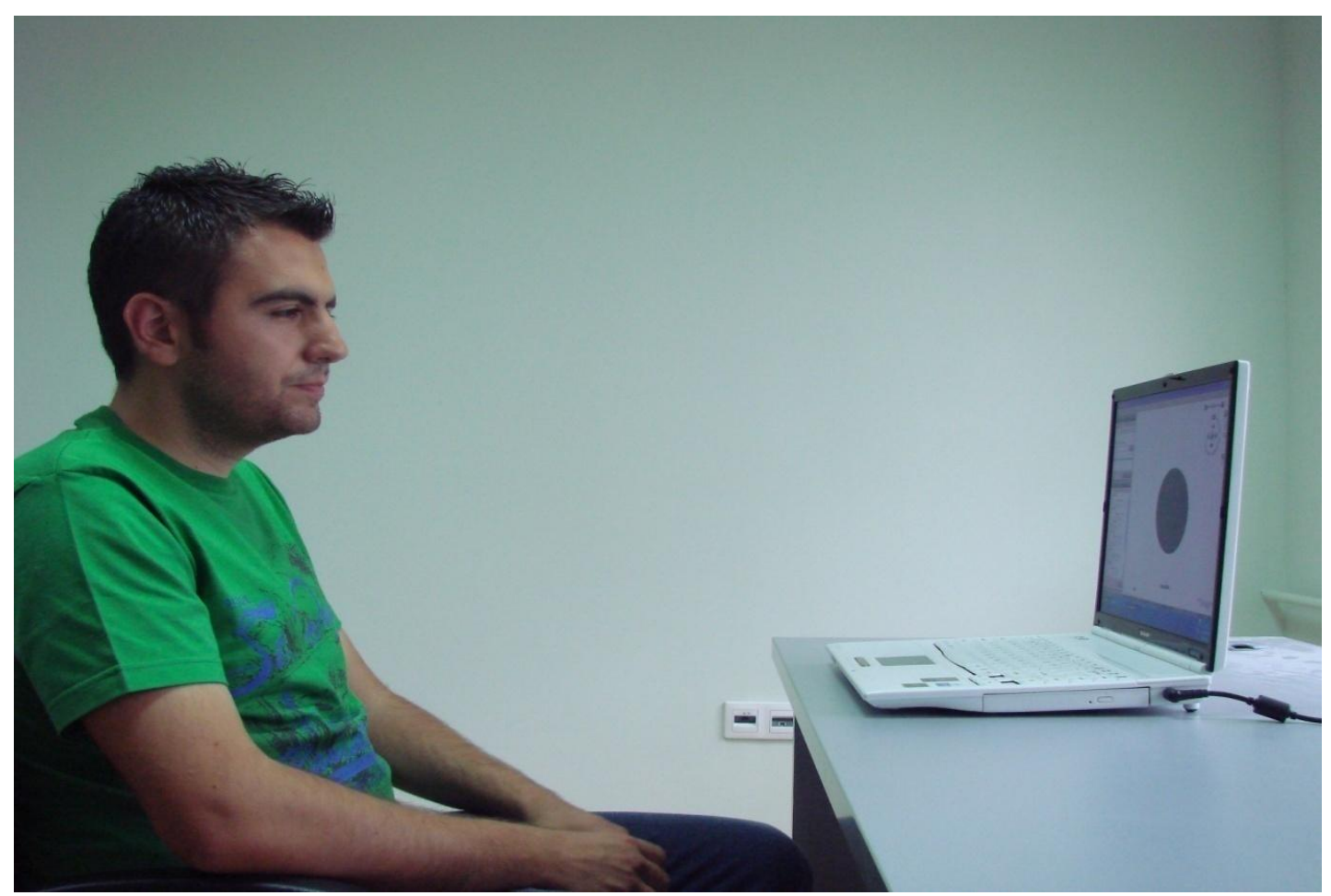

Figure 8: Experiment setup for 2D and 3D conditions 


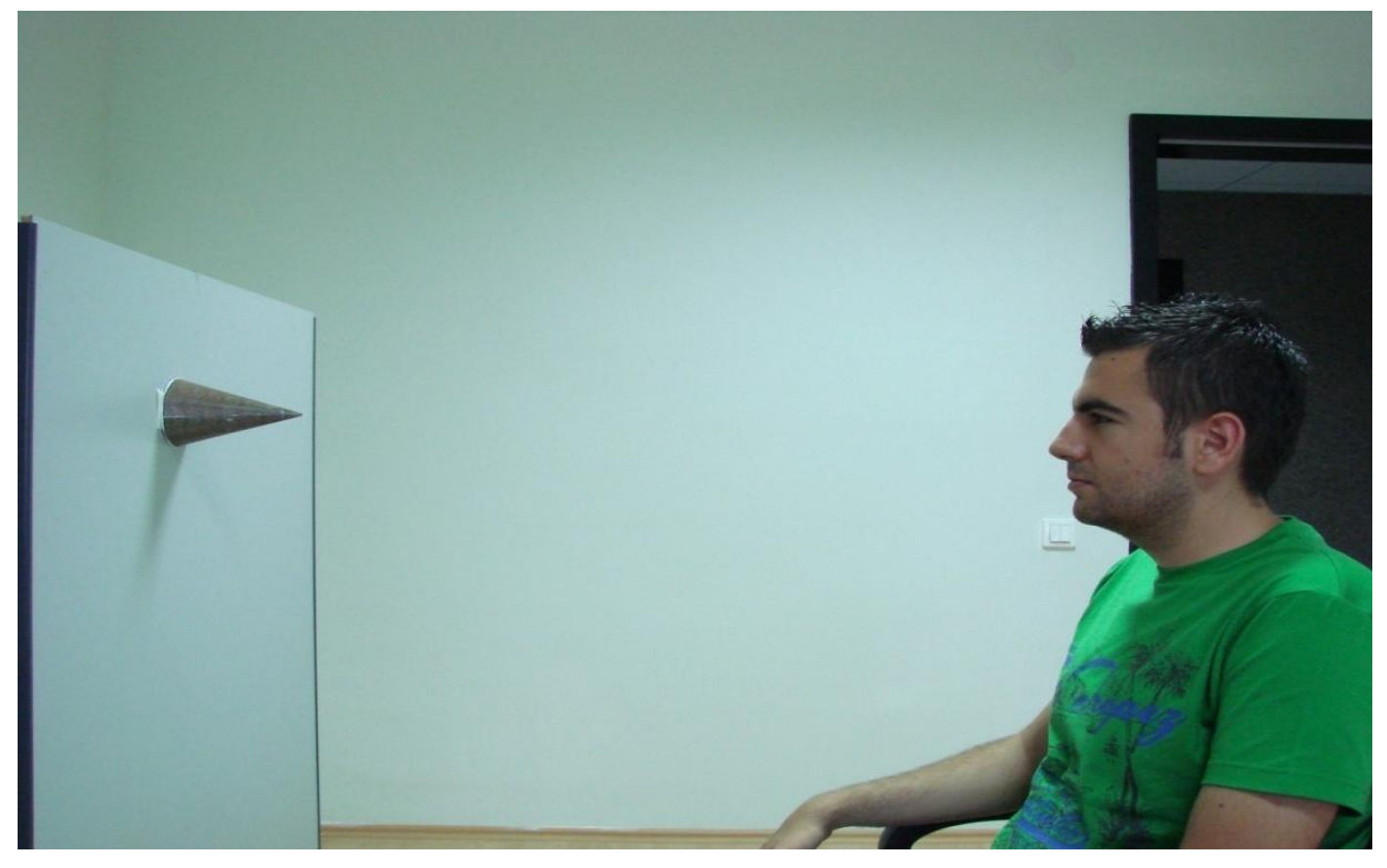

\section{Figure 9: Experimental setup for the Real condition}

In the last phase, participants were asked to fill in a post questionnaire. In addition, they were given de-brief information form. They were also offered cake and juice as a reward.

To summarize the experiment procedure, the sequence of the process is presented as below;

1. The participants read and signed the consent form,

2. Gathering demographic information about the participant,

3. Familiarization with the display,

4. For each cone (in 2D and 3D ) asking the participant to draw the shape's profile by assuming that it is the projection of a 3D object

5. Asking the participant to estimate the vertex (top angle) angle of the object,

And,

6. Asking the participant to answer post-test questions and giving de-brief form. 
Table 4: 2D projection of the cones

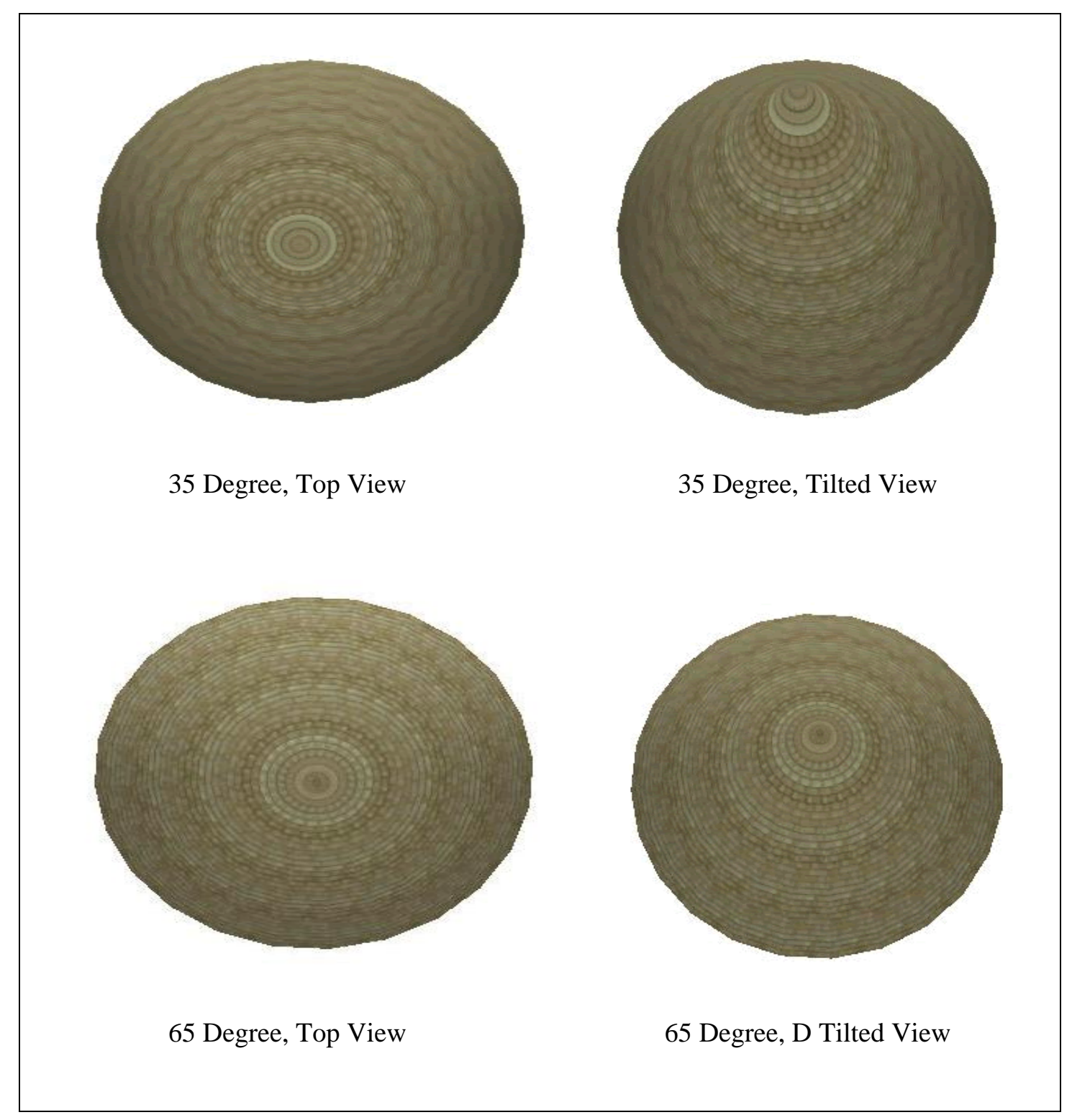


Table 4 Continued

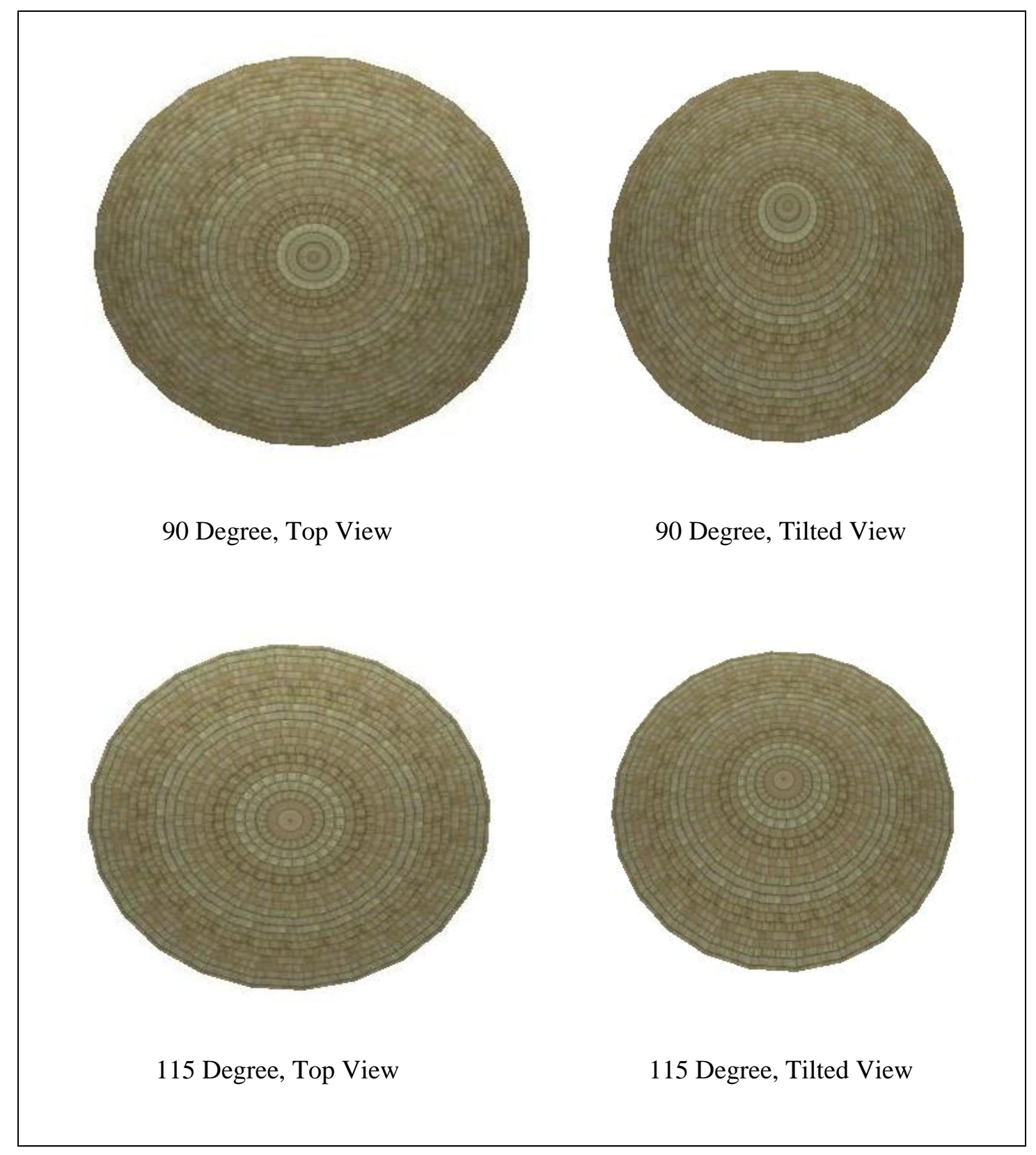




\section{CHAPTER 4}

\section{EXPERIMENTAL RESULTS}

In this chapter of the study, the result of the experiments for comparing angle and depth perception differences among 2D, 3D and Real conditions is presented.

\subsection{Learning Effect for Angle Estimation}

In order to validate that the randomization of the experiments successfully eliminated the learning effects, an analysis of variance test (ANOVA) was used. The results are presented in Appendix E. The order effects P-value $(0,103)$ indicates the absence of learning effects. That is, the order of questions asked to the participants does not influence the response accuracy. The graphical demonstration of the learning effect is presented in Figure 10. 


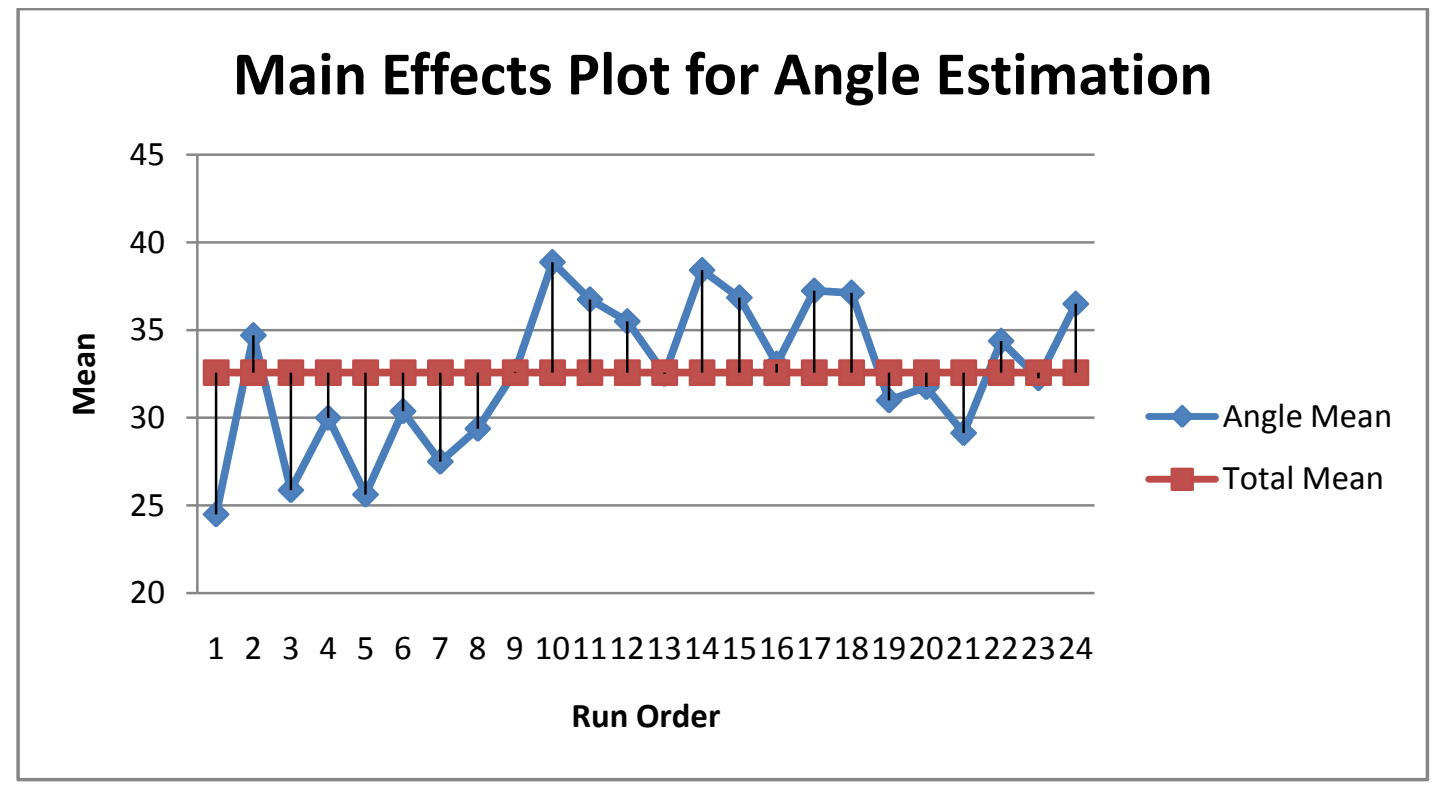

Figure 10: Learning Effect

After learning effect analysis, main analysis of the study will be presented. A general view of the experiment result is shown in Appendix F.

\subsection{Comparing Angle Estimation Accuracy}

\section{Comparing Angle Estimation Accuracy between 2D, 3D and Real Conditions}

In order to make general comparison for angle estimation accuracy, we should apply one way repeated ANOVA since we have more than two variables obtained from same subjects. The results show that estimation accuracy changes according to the condition which is the 2D, 3D and Real cases, $F(2,78)=29,713, \mathrm{p}<.05$.

We may report that, participants are more accurate in Real condition than in 3D and 2D displays. This is an expected result. In addition, the participants make more accurate estimations in the $3 \mathrm{D}$ condition than in the $2 \mathrm{D}$ one. This result is presented graphically in Figure 11. The dashed lines show diagonal view and straight lines show top view. 


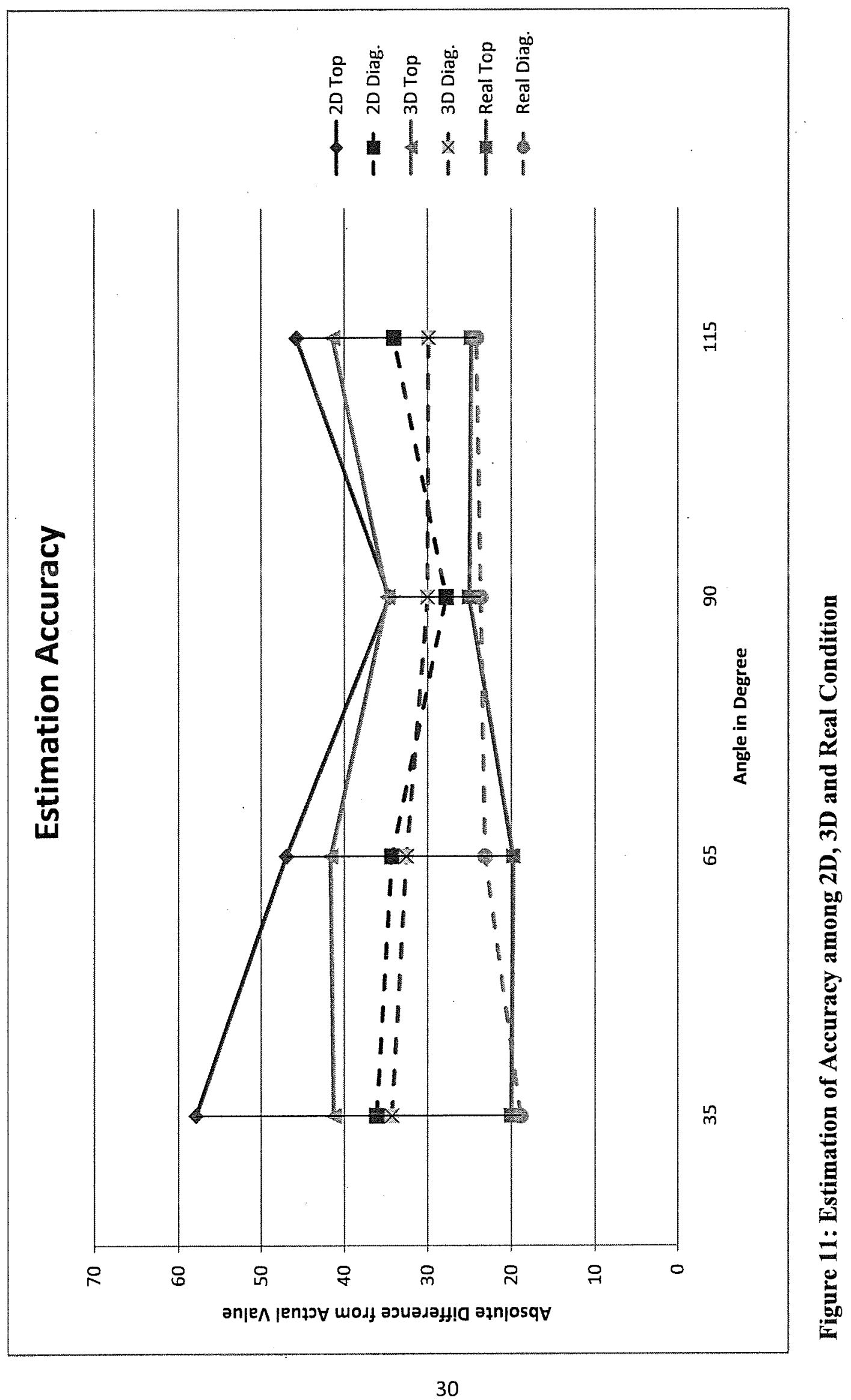




\section{Comparison of angle estimation accuracy between 2D and 3D Conditions}

Even though 3D results are better than 2D in Figure 11, when we make our analysis only between 2D and 3D, the result is slight different. There is no statistically significant difference between $3 \mathrm{D}$ and 2D in terms of accuracy according to the repeated measure $\operatorname{ANOVA}(\mathrm{F}(1,39)=2.409, \mathrm{p}=0.129)$. The graphical presentation of the result is shown in Figure 11.

After this general view of the estimation accuracy analysis, statistical test for estimation accuracy differences between 2D and 3D condition is conducted for top view and diagonal view separately. When we apply the repeated measure ANOVA for the top view, we may report that there is no significant difference between 2D and $3 \mathrm{D}$ condition in terms of accuracy $(\mathrm{F}(1,39)=3.741, \mathrm{p}>0.05)(\mathrm{p}=0,060)$ even though in terms of central tendency, 3D provides better angle perception than $2 \mathrm{D}$. The result is shown graphically in Figure 11.

The same comparison test is applied for diagonal view, and the result is parallel to the above mentioned analysis conducted for the top view. This means that 3D environment does not provide better angle perception performance than $2 \mathrm{D}(\mathrm{F}(1,39)$ $=.290, \mathrm{p}=0.593)$.

\section{Comparison of angle estimation accuracy between 2D and 3D for 35, 65 and 115 degree angle}

As it is clearly seen in the Figure 11, for 90 degree angle there is only a slightly difference between 2D, 3D and Real conditions in terms of estimation accuracy. The study conducted by Nundy et al (2000) indicates that for 90 degree angles, human perception is quite accurate. This statement leads us to analyze data without the 90 degree point since it has special situation. In other words, for the estimation accuracy, 35, 65 and 115 degree angles will be analyzed again. 
When we apply repeated measures ANOVA test on 35, 65 and 115 degree angle for $2 \mathrm{D}$ and $3 \mathrm{D}$ conditions and both types of view point, we can see that participants make more accurate estimation in $3 \mathrm{D}$ than in $2 \mathrm{D}$ condition $(\mathrm{F}(1,39)=4.926, \mathrm{p}<0.05)$ $(\mathrm{p}=0.032)$. We can also see the result in graphic format. In Figure 12, we can see the difference of participants' estimation accuracy between 3D and 2D conditions. The dashed lines show the diagonal view and straight lines show the top view.

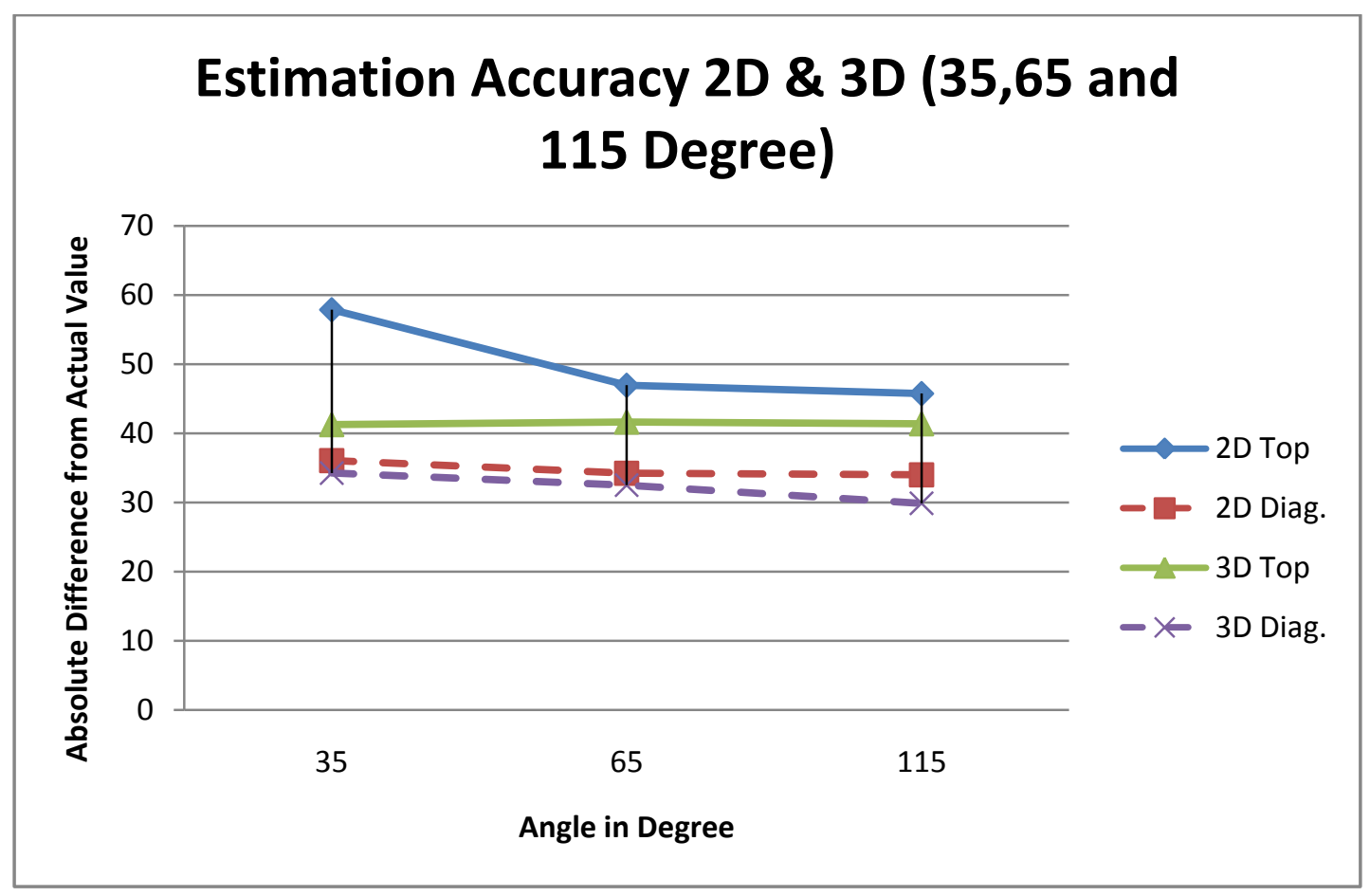

Figure 12: Estimation Accuracy between 3D and 2D (35, 65, 115 degree)

We can also report that estimations of the participants were more accurate when they looked at the cone images from the diagonal view point than from the top view point $(\mathrm{F}(1,39)=42.501, \mathrm{p}<0.05)$.

After this general view of the estimation accuracy analysis for 35, 65 and 115 degree angles, statistical test for estimation accuracy differences between $2 \mathrm{D}$ and $3 \mathrm{D}$ condition for three angles was conducted for top view and diagonal view separately. 
When we apply the repeated measure ANOVA to the top view in cases of 35, 65 and 155 degree angle, we may report that there is significant difference between 2D and $3 \mathrm{D}$ conditions in terms of accuracy $(\mathrm{F}(1,39)=6.672, \mathrm{p}<0.05)$.

The same analysis was applied for diagonal view. However, the result is slightly different from top view analysis. According to the repeated measure ANOVA test (35, 65 and 155 degree angle), we may report that there is no significant difference between $2 \mathrm{D}$ and $3 \mathrm{D}$ conditions in terms of accuracy $(\mathrm{F}(1,39)=.941, \mathrm{p}>0.05)$ $(\mathrm{p}=0.338)$ for the diagonal view.

Moreover, we can see from the graphics that, participants make more accurate estimations with the diagonal view than the top view. This statement is also supported by repeated measures ANOVA test $(F(1,39)=42.501, p<0.05)$. The viewpoint difference will be studied in more detail later.

\subsection{Comparing Angle Measurement Accuracy}

\section{Comparison of measured angle accuracy between 2D and 3D}

In this part of the analysis, measured angles of participants' drawings will be analyzed in terms of accuracy. In order to get the general idea about the differences between 2D and 3D conditions in terms of measured angle accuracy, we should apply repeated measures ANOVA test. According to the test results, we may report that participants make more accurate estimation in the $3 \mathrm{D}$ condition than in the $2 \mathrm{D}(\mathrm{F}$ $(1,39)=4.661, \mathrm{p}<0.05)(\mathrm{p}=0.037)$. The graphical demonstration of the result is shown in Figure 13. The dashed lines show diagonal view and straight lines show top view. 


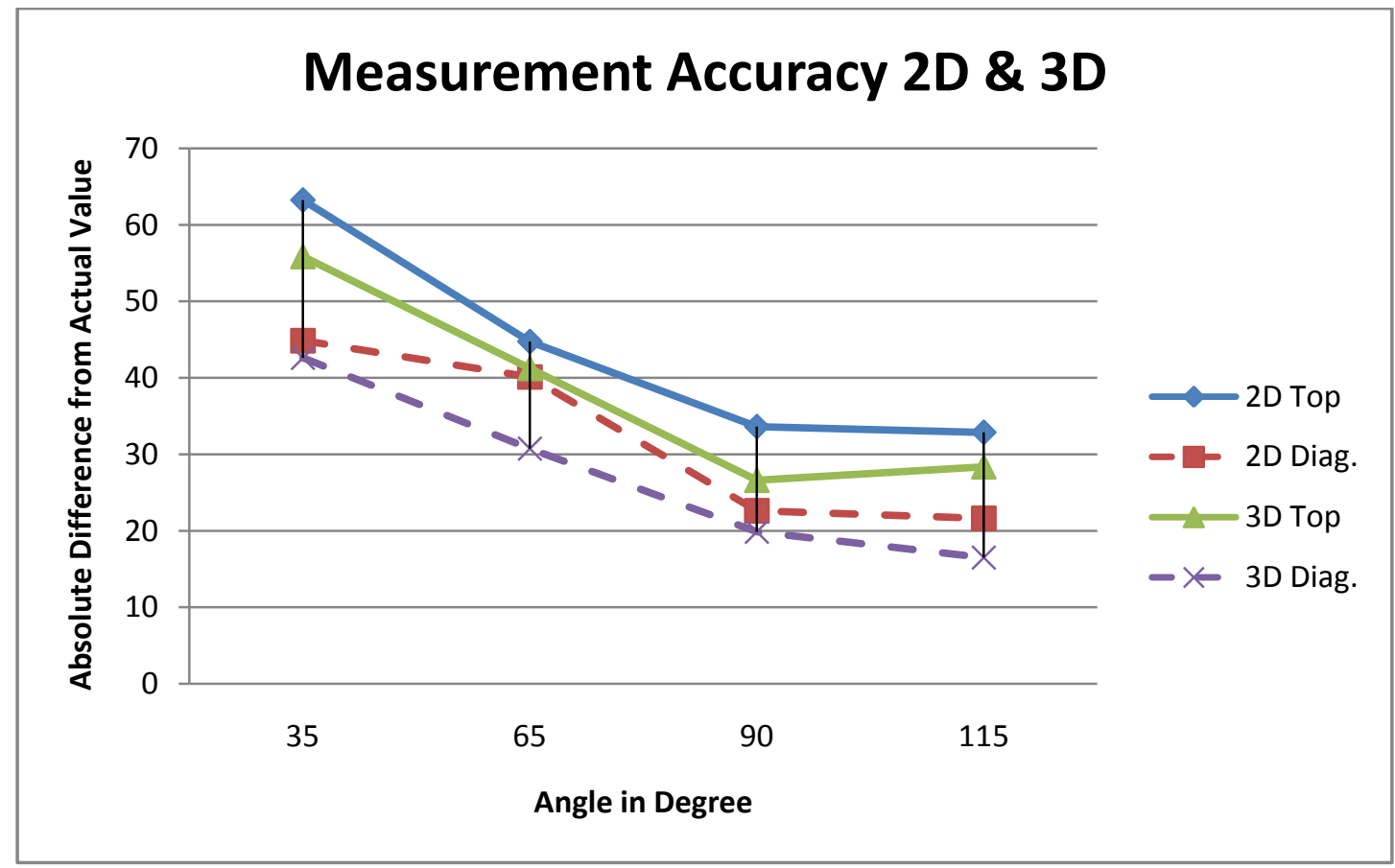

Figure 13: Measurement Accuracy between 2D and 3D Condition

Comparison of measured angle accuracy between 2D and 3D for 15, 65 and 115 degree angle.

When we exclude 90 degree point as in the analysis made for estimation accuracy, we also show that autostereoscopic 3D display provide better depth performance than traditional 2D display $(\mathrm{F}(1,39)=8.137, \mathrm{p}<0.05)$. The graphical demonstration of the result can be seen in Figure 14. 


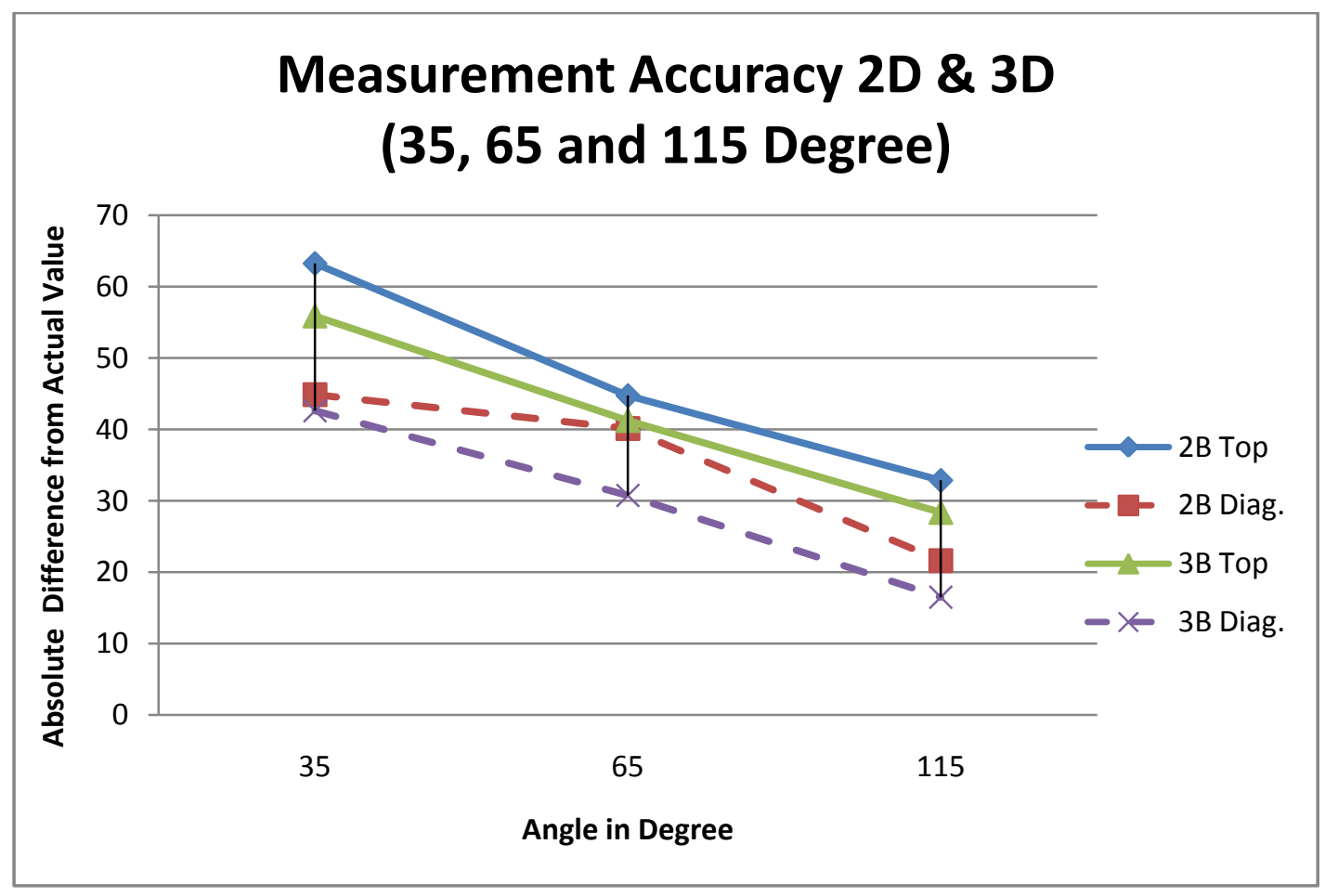

Figure 14: Measurement Accuracy between 2D and 3D (35, 65 and 115 Degree)

After this general view of the measurement accuracy analysis for 35, 65 and 115 degree angle, statistical test for measurement accuracy differences between 2D and $3 \mathrm{D}$ condition for the three angles is conducted for the top view and diagonal view separately.

When we apply the repeated measure ANOVA for the top view for 35, 65 and 155 degree angle, we may report that there is no significant difference between 2D and 3D condition in terms of measurement accuracy $(F(1,39)=2.149, p>0$. 05) $(\mathrm{p}=0.151)$.

The same analysis is also applied for the diagonal view. However, the result is slightly different from top view analysis. According to the repeated measure ANOVA test (35, 65 and 155 degree angle), we may report that there is a statistically significant difference between 2D and 3D condition in terms of measurement accuracy $(\mathrm{F}(1,39)=7.017, \mathrm{p}>0$. 05) $(\mathrm{p}=0.012)$. That is; participants draw more 
accurate angle of the object in 3D than 2D diplay. The graphical demonstration of this result is presented in Figure 14.

\section{Relationship between estimation and measurement}

During the experiment participants were asked to estimate the angle of the cone showed on the screen, and to draw the projection of the object. After the experiment, all drawings were measured using protractor. In this part of the analysis, we explore the differences between angle estimations and angle measurements of participants. This analysis will also be made for accuracy differences between them.

Before making statistical tests, general demonstrative presentation of differences between estimated and measured angle for 2D (Figure 15) and 3D (Figure 16) condition is stated below. The dashed lines show diagonal view and straight line show top view.

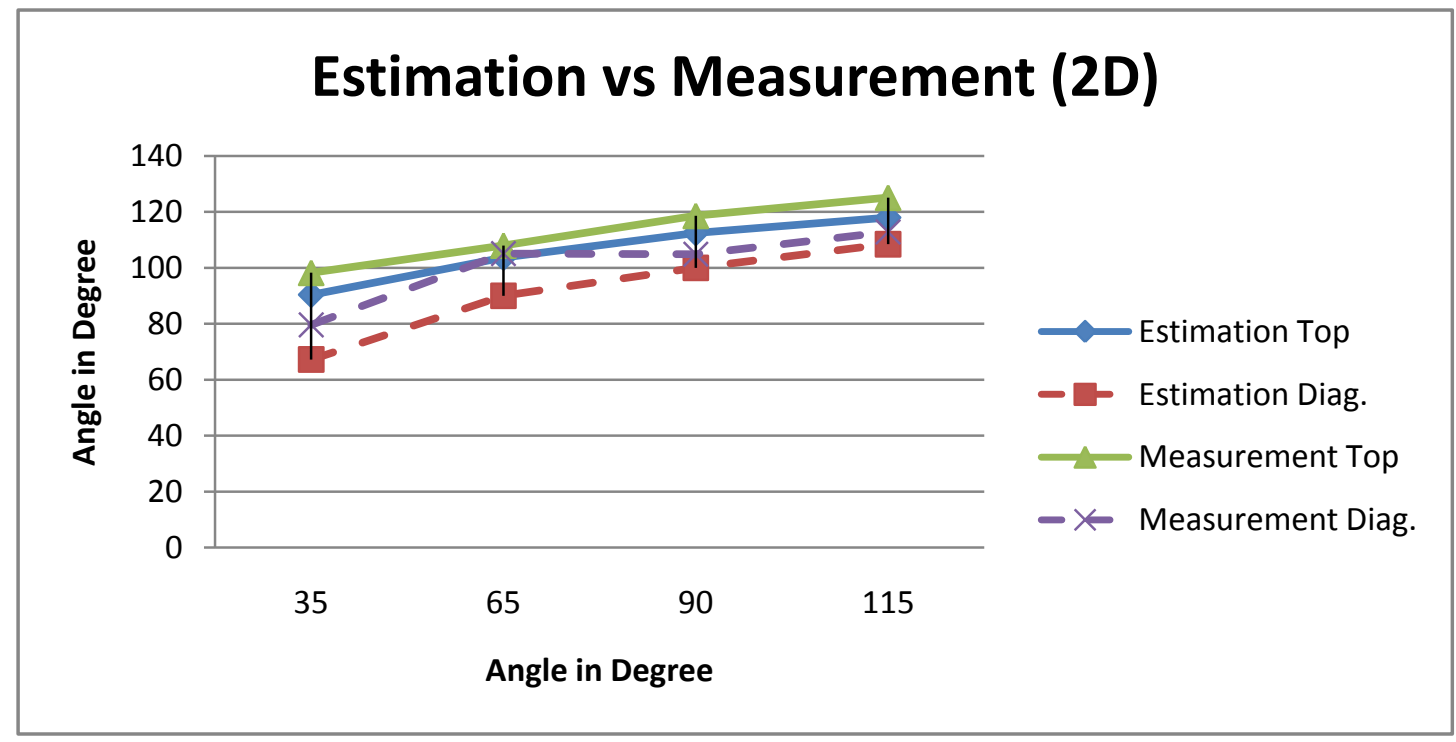

Figure 15: Estimation vs Measurement for 2D Condition 


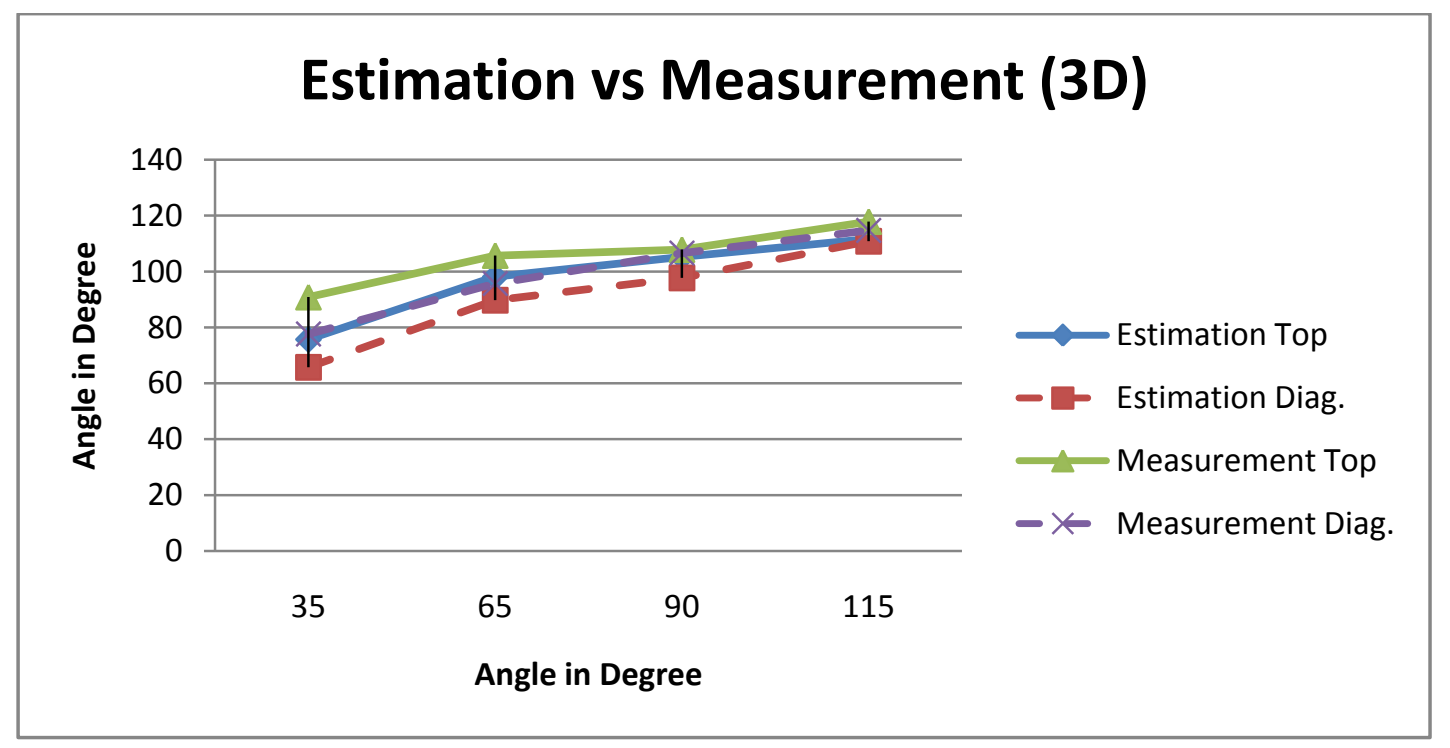

Figure 16: Estimation vs Measurement for 3D Condition

After this graphical presentation we apply the repeated ANOVA test to data. According to this test we can claim that participants' estimations are smaller than their measurement $(\mathrm{F}(1,39)=5.183, \mathrm{p}<.05)$. This analysis provides an opinion about general tendency of measurement and estimation values but it does not give any idea about accuracy differences between measured and estimated values. So, we should also analyze estimation and measurement differences in terms of accuracy. To do this, we should apply again repeated measures ANOVA for general comparison.

According to this test, we may report that there is no significant difference between estimated and measured values in terms of accuracy $(F(1,39)=2.233, p>.05)$ $(\mathrm{p}=0.143)$. The result is parallel with the $2 \mathrm{D}$ conditions $(\mathrm{F}(1,39)=1.58, \mathrm{p}>.05)$ $(\mathrm{p}=0.288)$ and the $3 \mathrm{D}$ condition $(\mathrm{F}(1,39)=2.531, \mathrm{p}>.05)(\mathrm{p}=0.120)$. We can see these results in a graphical demonstration in Figures 17 and 18. 


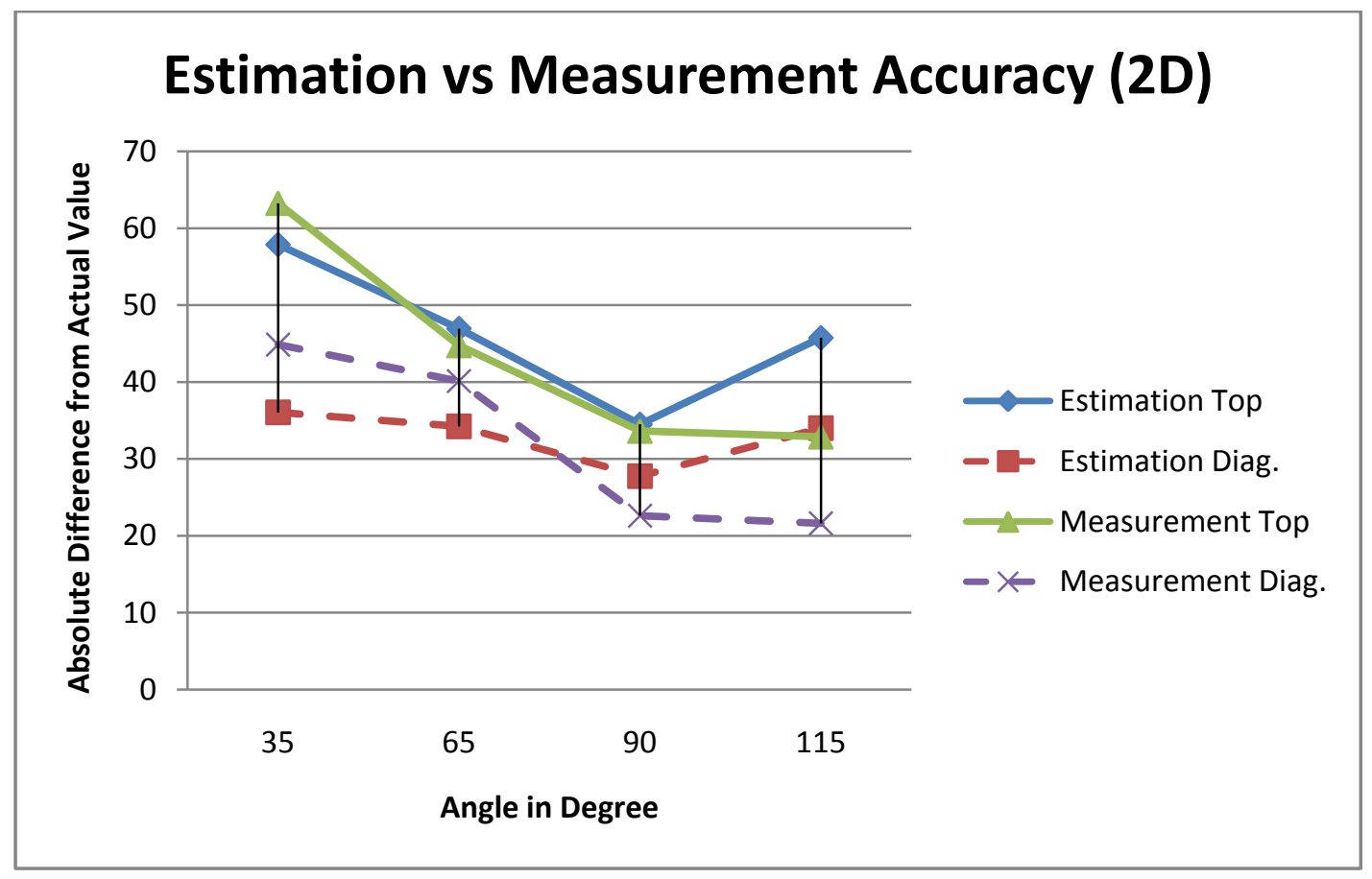

Figure 17: Estimation vs Measurement Accuracy in 2D

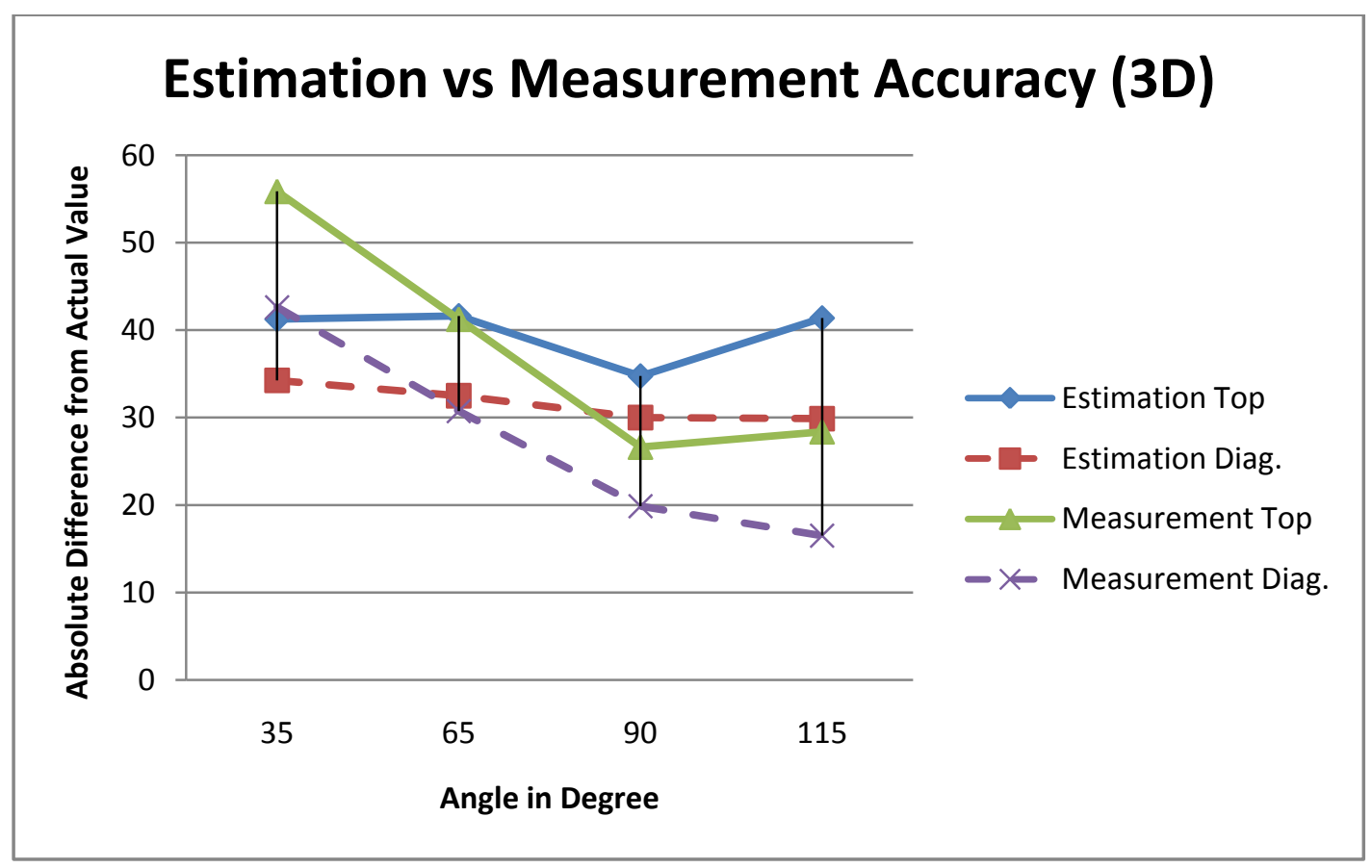

Figure 18: Estimation vs Measurement Accuracy in 3D

In the above analysis, we have compared estimation and measurement values separately for two conditions. In order to compare 2D and 3D conditions in terms of 
both estimation and measurement we should conduct repeated measures ANOVA test. The test was applied for the top view and the diagonal view separately. For the top view, there is no significant difference between 2D and 3D in terms of measured angle accuracy $(\mathrm{F}(1,39)=1.382, \mathrm{p}>.05)(\mathrm{p}=0.247)$. For the diagonal view the result is parallel $(\mathrm{F}(1,39)=2.208, \mathrm{p}>.05)(\mathrm{p}=0.145)$. These two results can be seen in Figure 19 and Figure 20. In these figures, dashed lines show measured values and straight lines show estimation values.

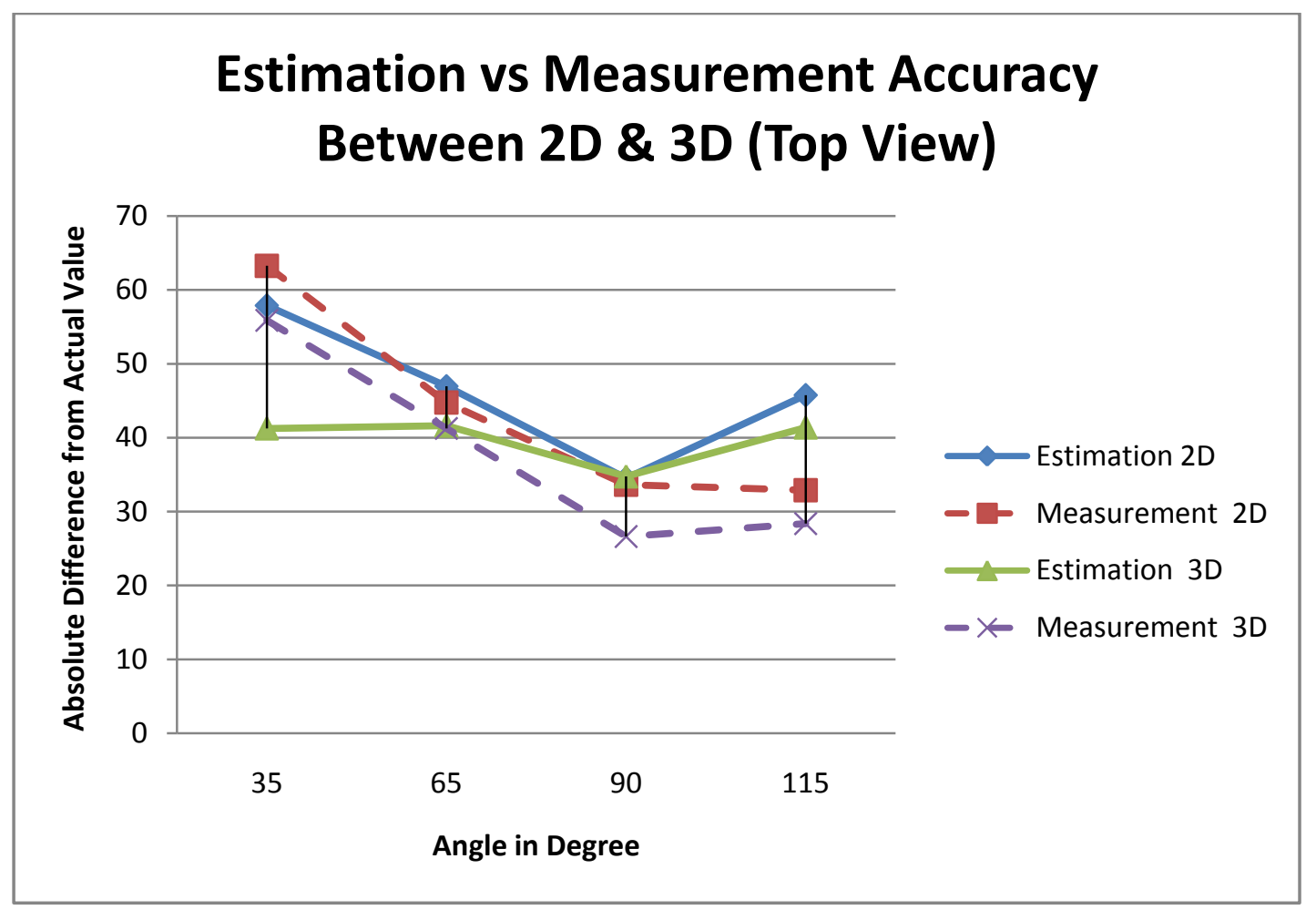

Figure 19: Estimation and Measurement Accuracy between 2D and 3D (Top View) 


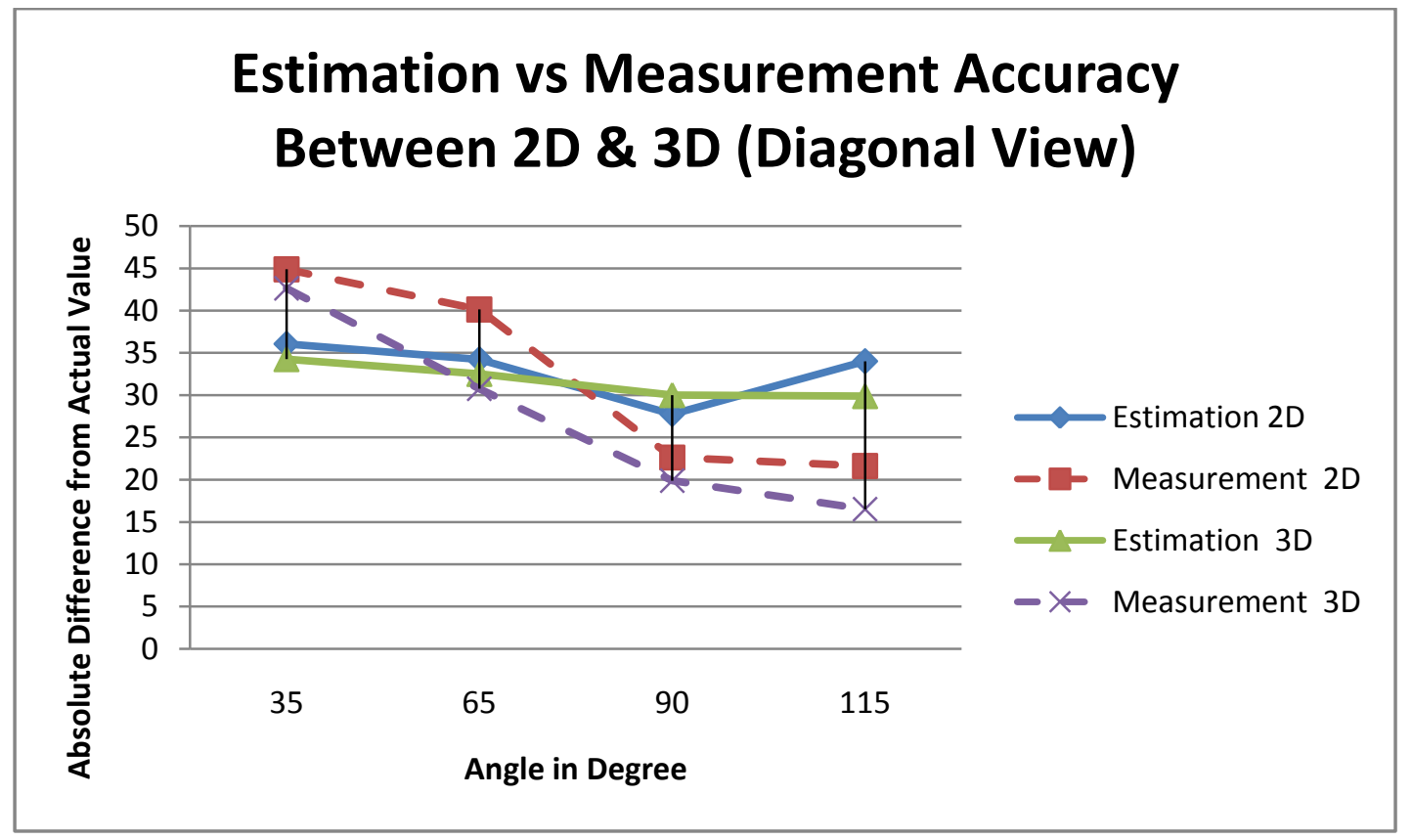

Figure 20: Estimation and Measurement Accuracy between 2D and 3D (Diagonal View)

\subsection{Overestimation and Underestimation Analysis}

According to the study conducted by Nundy et al (2000) observers tend to overestimate the magnitude of acute angles and underestimate obtuse ones. In order to check this statement in our experiments, we subtracted angle estimations from actual values. In Figure 21, we can see the over - under estimation tendency of participants' estimations. 


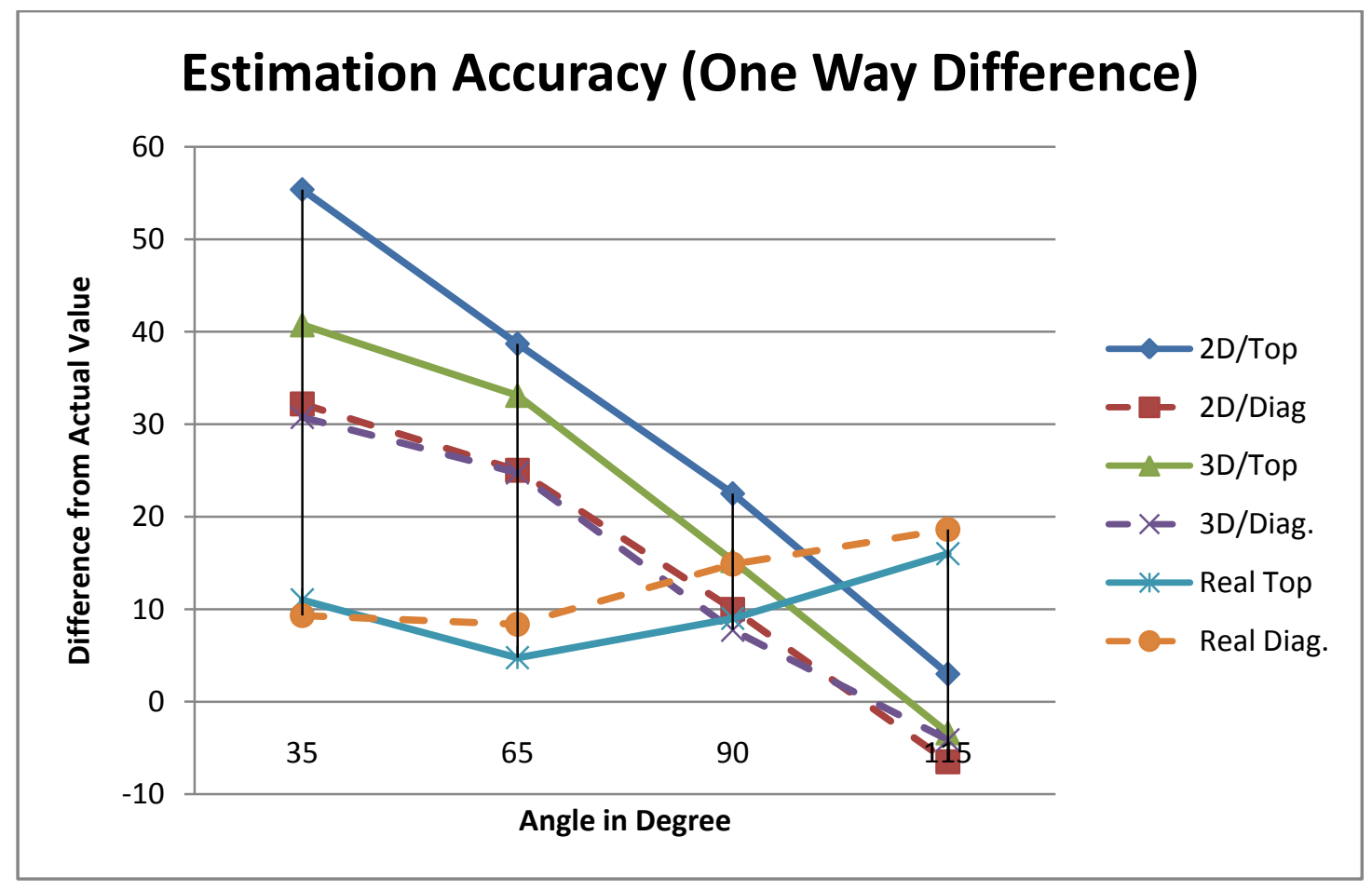

Figure 21: Estimation Accuracy (One Way Difference)

As it is clearly seen in the figure, participants overestimate all angles in the 2D condition with the top viewpoint. However, when they look the objects from the diagonal viewpoint in the $2 \mathrm{D}$ condition they overestimate 35, 65 and 90 degree but underestimate 115 degree angle. In the 3D condition for both viewpoints, they overestimate 35, 65 and 90 degree angle but underestimate 115 degree. We can generalize for the 3D condition that the participants overestimate acute angle and underestimate obtuse ones. Interestingly, for the Real condition, they overestimate all the angles for both types of viewpoints.

On the other hand, we can compare the measurements of the participants in terms of over and underestimation. General view of the participants' measurements is presented in Figure 22. 


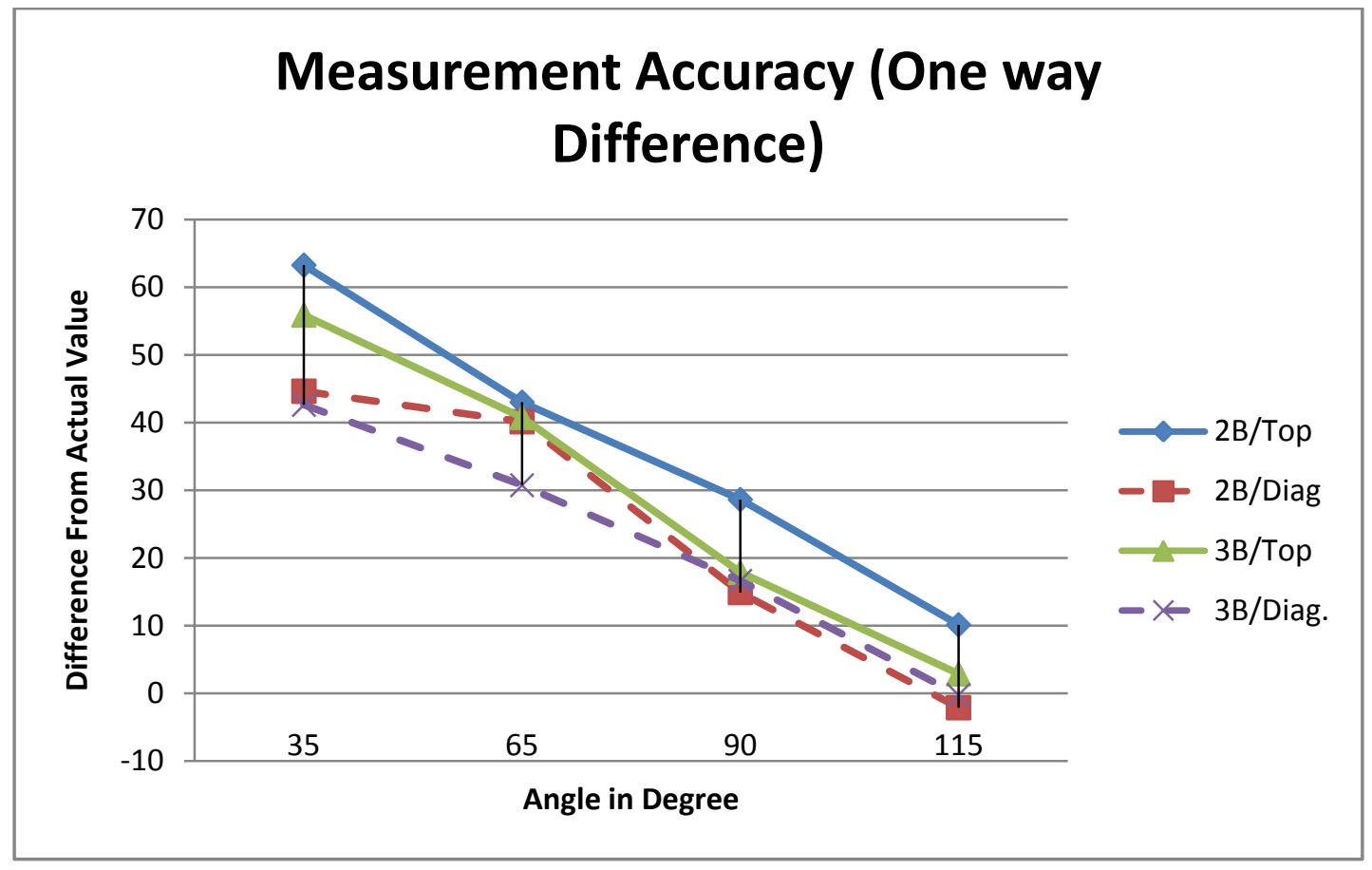

Figure 22: Measurement Accuracy (One Way Difference)

Since the participants were not asked to draw a projection of the object in Real condition, we do not have measurements for the real life. So we can make comparisons just for $2 \mathrm{D}$ and $3 \mathrm{D}$ conditions. For 2D conditions, the participants' measurements are greater than actual value for all angles when they look at the objects from above. However, when they look from the diagonal viewpoint at the objects, they draw the projection smaller than the actual value for the 115 degree angle. For 35, 65 and 90 degree angle objects, their projections are greater than actual value as expected according to the literature. This result is parallel to the $3 \mathrm{D}$ condition. When the participants look at the object from the top viewpoint, their drawings are greater than the actual values for all the angles. However, when they look at the object from the diagonal viewpoint they draw the projection smaller than the actual value for 115 degree angle. For 35, 65 and 90 degree angle objects, their projections are drawn greater than their actual value.

A more detailed analysis is available in Appendix I. Estimation accuracy, drawings accuracy and over-under estimation analysis for each angle are provided in the Appendix I as graphical demonstration. 


\subsection{Questionnaire Results}

The results of pre-questionnaire and post-questionnaire are discussed in this section.

\subsubsection{Pre-Questionnaire Results}

In the pre-questionnaire; the age, vision problem, experience about stereoscopic displays and the frequency of game play information were collected. According to the correlation analysis, there is no relationship between these demographic information and accuracy in the 2D, 3D and Real conditions.

\subsubsection{Post-Questionnaire Results}

In order to get the idea of participants about autostereoscopic 3D display and verbal comparison of the display with $2 \mathrm{D}$ and Real condition they were asked to fill in a post-questionnaire form. The questionnaire includes three questions see (Appendix A). The first one is about their estimation accuracy. In other words, they were asked to sort the conditions in accordance with their perceived accuracy. The second question is about the immersiveness of the conditions. In the third question, the participants were asked to suggest usage area of autostereoscopic displays.

According to the overall result mentioned above, the participants made their estimation more accurate in Real condition than in $3 \mathrm{D}$; also they were more accurate in $3 \mathrm{D}$ than in $2 \mathrm{D}$ condition. The answers of the first question of post-questionnaire are parallel to the actual result. 32 of 40 participants stated that the order of the accuracy according to the condition is Real, 3D and 2D conditions. The other five participants differed; they stated that they were more accurate in Real than in 2D and than in $3 \mathrm{D}$ condition.

In terms of immersivenes feelings, 24 participants stated that Real condition provides more immersive feelings than $3 \mathrm{D}$, and $3 \mathrm{D}$ provides more immersive feelings than 2D. On the other hand, 11 of 40 participants thought that autostereoscopic 3D display provide more immersive feelings than Real and, than 2D conditions. 
Suggestions of the participants about usage area of the Autostereoscopic 3D displays are varied. Forty one different usage areas were suggested by the participants. When we combine these suggestions we reach three main usage areas of using autostereoscopic 3D displays. These are entertainment, modeling and simulation, and education. In the field of the entertainment, TVs, cinema and games are the most common suggestion. On the other hand, 3D image modeling, simulation of a phenomenon and animations are some examples suggested by the participants for modeling and simulation area. Education in military, medical and other fields is the usage areas of autostereoscopic displays. Beside these, communication on autostereoscopic displays is another interesting suggestion. In fact, in the study conducted by Aplaslan et al, (2005) these usage areas of autostereoscopic displays were mentioned. In general, the participants' suggestions are parallel to the mentioned study.

\subsection{Discussion}

Since the autostereoscopic display support the Google Earth Software was used in our experiment to show the objects to the participants, our findings depend on this software's quality and compatibility. The study may be conducted with other software such as 3D Max. The selection of software depends on the availability of a plug-in or direct support to for the autostereoscopic displays.

During the experiment, we show the objects to the participants from two viewpoints. The first view point is totally above of the object. That is; the participants looked at the objects with zero degree tilt. The other viewpoint, called diagonal, is with fifteen degree tilt. These two viewpoints are also applied for Real conditions. The interesting point is that the participants overestimate all the angles. The study by Nundy (2000) indicates that obtuse angles would be underestimated. We believe the discrepancy is due to the viewing angle: the $3 \mathrm{D}$ objects are viewed from the top or with 15 degree tilt. Nundy's results should apply to tilting the object by 90 degree, or viewing its profile.

The same finding applies to the 3D case. In particular all estimations deviate from the actual values between 50 degree and 20 degree depending on the case. 


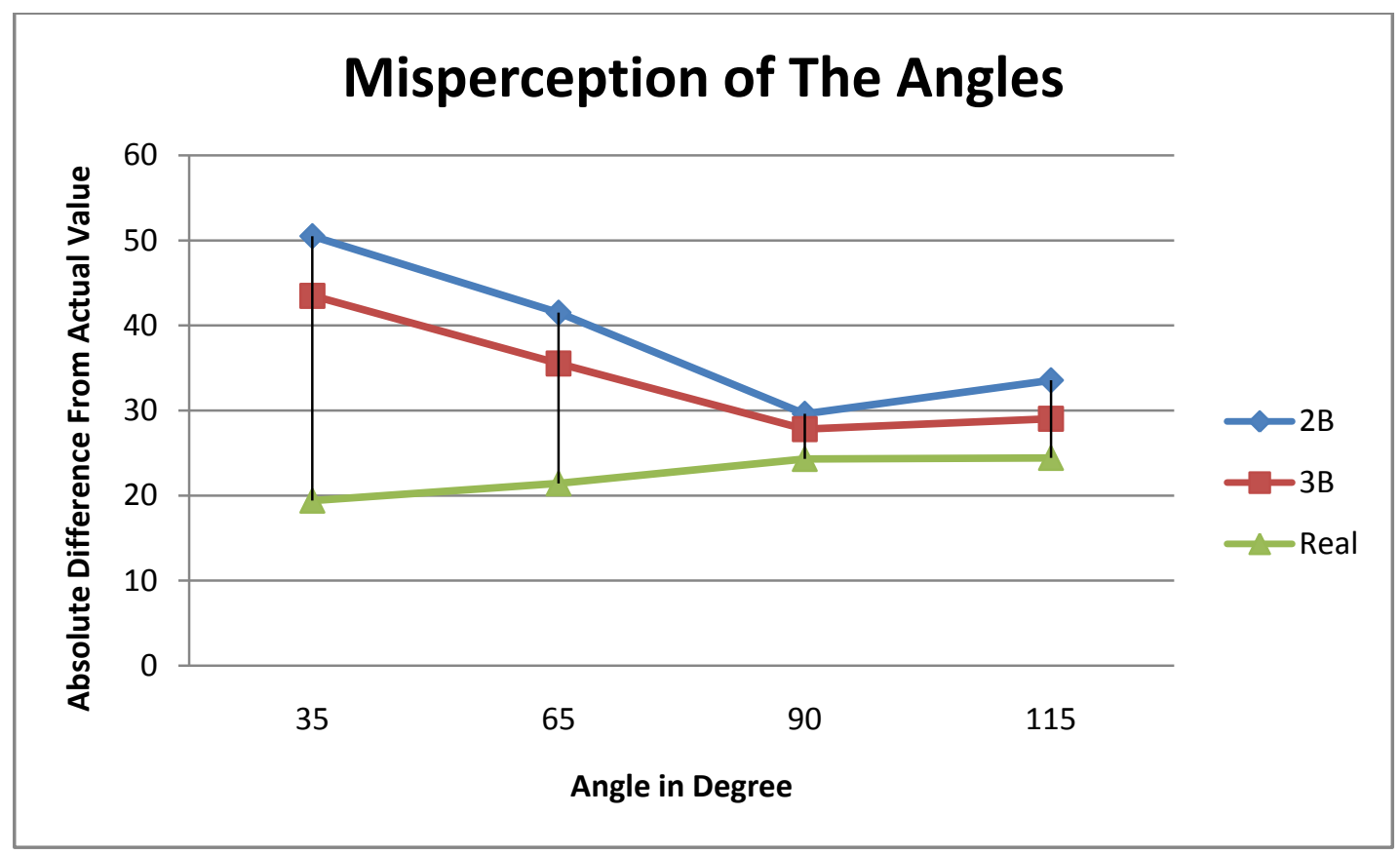

Figure 23: Misperception of the Angles (Absolute Difference)

As seen in the Figure 23, even in Real condition the participants perceive angle with 20 degree error. This may be because of the viewpoints or the complexity of the objects shown to the participants.

When we explore the case with the one way difference values, we saw that the case is slightly different. This time, for the angles of 35, 65 and 90 degree, the participants more overestimate the angles in 2D than in 3D condition. Similarly, they more overestimate the angles in 3D than in Real condition except for 115 degree. The participants more overestimate 115 degree angle in Real than in $2 \mathrm{D}$, and they more overestimate the angle in $2 \mathrm{D}$ than in $3 \mathrm{D}$ conditions. The cases can be seen in the Figure 24. 


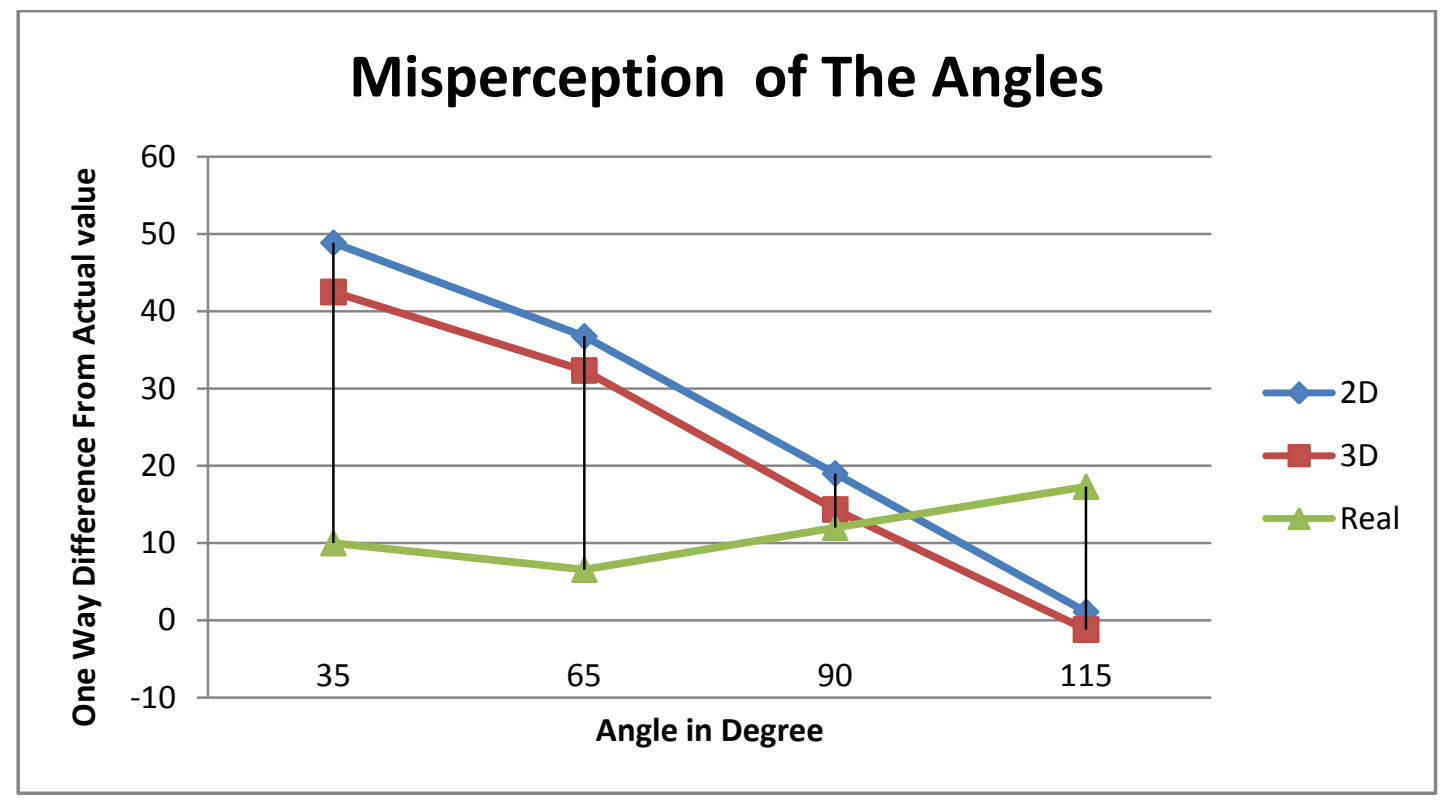

Figure 24: Misperception of the Angles (One Way Difference)

We suspected this result may be due to the selected textures of the Real objects. In the process of preparing the Real objects, we tried to replicate the objects used in the $3 \mathrm{D}$ and 2D conditions in the Real ones. So we decided to map the real objects with the same textures of the virtual objects.

In order to check if the texture on the real cones contributes to this misperception, we conducted a post experiment with ten participants. In this experiment we asked the participants to estimate the vertex angle of the 115 degree Real cone from two different viewpoints as in the main experiment. In addition, they were also asked to estimate vertex angle of the cone after the texture on the real cones is taken off. After analyzing this experiment's results we saw that their estimations without texture even were worse (Figure 32). We may say that texture did help the participants to make more accurate estimation. Then we repeated the experiment in the literature regarding of an obtuse angle. The findings in the literature applied to angle on a $2 \mathrm{D}$ surface. The participants were shown a 115 degree angle on paper from one viewpoint and asked to estimate the angle of the shape. The participants underestimated the real angle as reported in the literature. The results show that the overestimation of obtuse angle in 3D objects may be characteristic to 3D structure of the objects (Figure 25). 


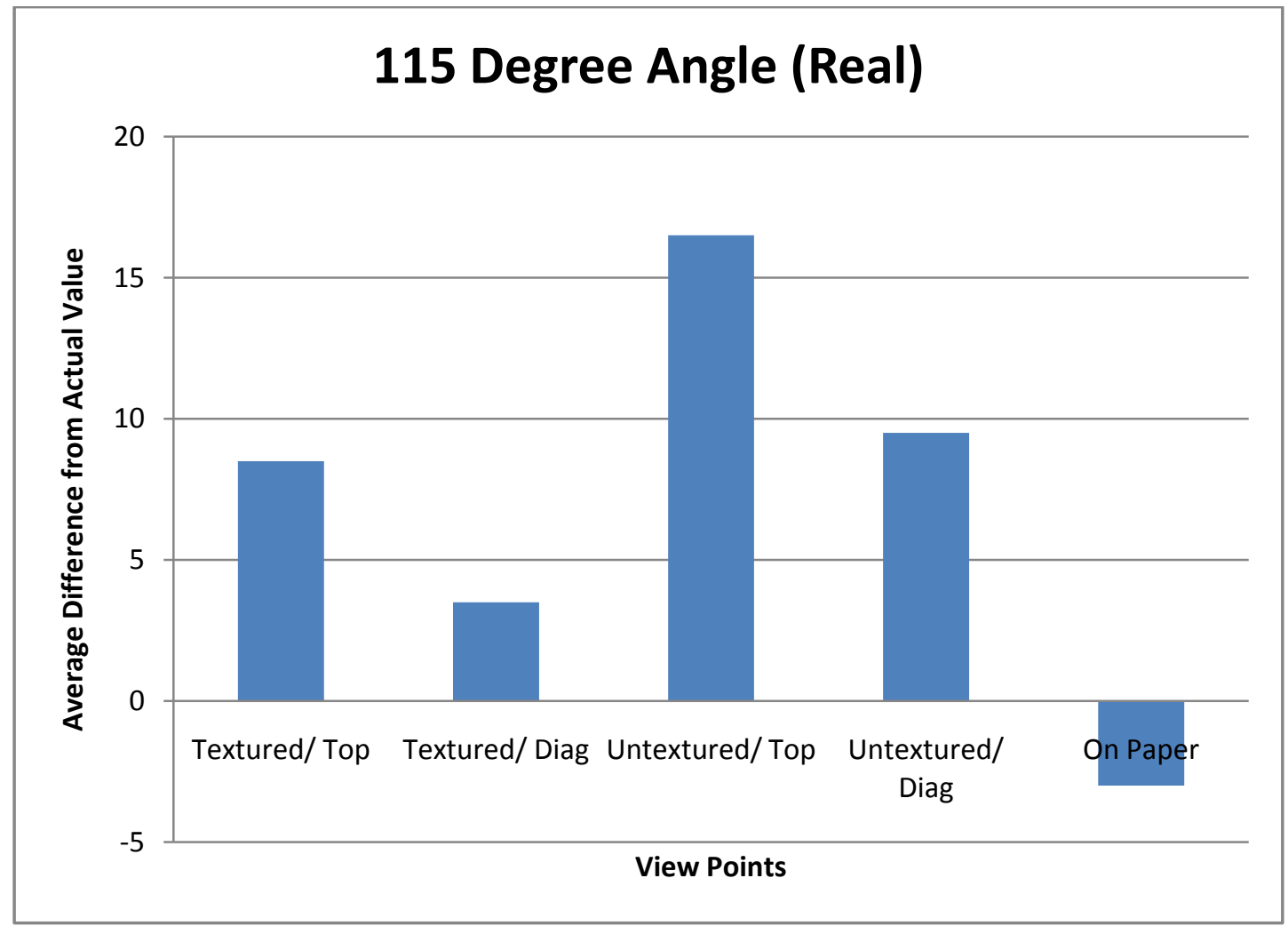

Figure 25: Texture effect on angle misperception. 


\section{CHAPTER 5}

\section{CONCLUSION AND FUTURE STUDY}

This chapter includes main findings of the experiment and future study.

\subsection{Conclusion}

The study was conducted to compare angle perception difference between autostereoscopic 3D display and traditional 2D display. For this purpose two experiments were conducted. The first experiment may be thought as a pilot study. According to the pilot study results we decided to apply the main experiment to explore angle perception differences among Real condition, on autostereoscopic 3D displays and on 2D displays. Angle and viewpoint parameters were investigated. Forty people participated in the main experiment. An autostereoscopic 3D laptop was used to display objects. Since the laptop is switchable to 2D and 3D mode, we used it also for the 2D view. In order to show the objects during the experiment, Google Earth software was used. Four different cones were used in the experiment. They were viewed from two different viewpoints. The participants were asked to estimate the vertex angle of the cones. In addition they were also asked to draw the projections of the cones. We also conducted the experimental task in Real condition with the cones which have the same properties with the cones used in virtual condition. 
This gives an opportunity to compare Real, 3D and 2D conditions in terms of angle perception differences. In addition, we applied post-questionnaire to understand the participants' opinion about autostereoscopic display.

For the analysis, SPSS 15.0 software was used. The main analyses were classified in four categories; Estimation Accuracy, Drawings Accuracy, Comparing Drawings and Estimations and over-under estimation analyses.

In general we may say that participants make the most accurate estimation in Real condition. However, they were more accurate in $3 \mathrm{D}$ than in $2 \mathrm{D}$ condition. This shows autostereoscopic 3D displays can be more effective in displaying 3D shapes.

During the experiments, participants viewed cones from two different viewpoints; totally top view and diagonal view (with 15 degree angle tilt). According to the comparison of these two viewpoints in terms of accuracy, we may also report that participants were more accurate in 3D than in 2D. However, this difference was not statistically significant. It should be noted that this result holds for all types of angles.

Since the accuracy differences between Real, 3D and 2D conditions are relatively small for 90 degree angle cone, we applied the test by excluding the 90 degree angle. According to the study conducted by Nundy et al (2000), for angle perception, in 90 degree angle observers make slightly smaller estimation errors than acute and obtuse ones. Between the two view, the participants made more accurate estimations in $3 \mathrm{D}$ condition than $2 \mathrm{D}$.

In addition to angle estimation, the participants also drew the projection of the cone in the questionnaire as if they were looking at the objects from the side. In fact they were asked to draw what they see rather than what they estimate. Their drawings were measured using a protractor, and the values were also analyzed in terms of accuracy.

According to these drawings we may report that the participants' accuracy is significantly higher in $3 \mathrm{D}$ condition than in $2 \mathrm{D}$ for both type of viewpoints and for all angles. Moreover, when we exclude the 90 degree angle from our analysis, the result does not change. 
When we compare measured angles from drawings with the estimation value, we see that participants' estimations are smaller than drawings in general. However, this is not a statistically significant result. Since the participants were not asked to draw projection of the Real cone, we cannot compare Real condition in this analysis.

In terms of accuracy relationship between estimation and drawings, we could not generalize the participants' tendency since the relation is different for each angle. However, we may report that drawings were more accurate than estimation in 115 degree angle for both types of view points and both types of condition (2D \& 3D).

After the analysis of the one way difference of the estimation values from the actual values we observe that the participants overestimate all the angles in Real condition for both view point. Moreover, they overestimate all the angles in 2D with the diagonal view. However, the participants over estimate 35, 65 and 90 degree angles and slightly underestimate 115 degree angle in 2D with diagonal view. In 3D condition, 35, 65 and 90 degree angles were overestimated but 115 degree angle was underestimated for both viewpoints.

Lastly, the above analysis was also made for measured values from the drawings of the projection of the cones. The participants over draw the all angles in both type of condition when they looked at the object from totally above. However, for the diagonal view, they overdraw the projections of 35, 65 and 90 degree angle cones but underdraw 115 degree angle cone as it is expected according to the study by Nundy et al. (2000).

For the correlation of accuracy with gender, 3D experience, age and education level of the participants, we may say that no relationship between such demographic information and accuracy could be found. This is also may be due to the uniformity of the subject group.

In the lights of this information, we may conclude that Autostereoscopic 3D display enables the user to perceive angles more accurately than traditional $2 \mathrm{D}$ displays. As the vertex angle and depth are related we may reach that Autostereoscopic 3D displays provide more depth information than $2 \mathrm{D}$ to the users. 
How this study contributes to science or to society is another important issue. The result of this study may contribute to the development of autostereoscopic 3D simulators or displays. Moreover, this study may also guide to 3D model designers. It is clear that stereoscopic displays will become more common in the upcoming years. So the 3D model development will reach a new dimension. Furthermore, the study provides new methodology for the depth perception experiments. This method may be tested in terms of validity by another research. Lastly, this study also gives an opinion about the compliance of autostereoscopic 3D Display and Google Earth software. Google Earth software developer can use the results of this study to improve compatibility of the software with autostereoscopic 3D Display.

\subsection{Future Study}

The experiment was conducted with four different angles and two different viewpoints to investigate the angle perception performance on 3D display. These objects were shown statically by using the Google Earth. In order to provide more information, the study may be modified to include dynamic scenes and more complex shapes.

We used cones as the $3 \mathrm{D}$ object to test the angle perception and they were shown from top and diagonal viewpoint. However we did not show the objects to the participants from the bottom side. That is, we tested just the convex view of the objects. In order to compare $2 \mathrm{D}$ and $3 \mathrm{D}$ displays in terms of immersiveness, the objects may be shown in a concave view.

Since we used Google Earth software for the experimental task, we are limited with the quality and compatibility of the software. For this experimental task, other software such as 3D Max may be used. Also, two or more software may be compared in terms of the compatibility with the autostereoscopic 3D display.

The experiment can be repeated on a larger group with more variety to see of age, experience, education level etc. have any effect. The users may be requested to estimate the depth of the object directly rather than angle. This would give more insight for depth perception. 
In addition to autostereoscopic displays, stereoscopic displays with additional equipment such as shutter glasses or even other 3D display like holographic ones can be used for comparison.

Lastly, these findings need to be analyzed from Cognitive Science perspective to see how they are supported by human vision and perception. 


\section{REFERENCES}

Alpaslan, Z.Y., Yeh, C.A., Rizzo, A., \& Sawchuk, A. (2005). Quantitative Comparison of Two Stereoscopic Three-Dimensional Computer Interaction Methods. Proc. Stereoscopic Displays and Virtual Reality Systems XII Symposium, Proc. SPIE, 5664.

Andy, F. (2005) Discovering Statistics Using SPSS. London: SAGE

Bigham, D. D. (2000). Distance Perception and Visualization Using Virtual Environments. Naval Postgraduate School, Monterey, CA.

Carpenter, R.H.S \& Blakemore, C. (1972). Interactions between orientations in human vision. Experimental Brain Research, 18 (3), 287-303

Çetin, Y. (2008). Evaluation of visual cues of three dimensional virtual environments for helicopter simulators. Unpublished doctoral dissertation, Middle East Technical University, Ankara.

Dodgson, N.A.(2005). Autostereoscopic 3d displays. IEEE Computer, 38, 31-36

Dodgson, N.A., Moore, J.R.\& Lang, S.R. (1999). Multi-view autostereoscopic 3D display. $I B C$ '99, 497-502

Greene, E. (1994). Collinearity judgment as a function of induction angle. Perceptual \& Motor Skills, 5, 1871-1880.

Grossman, T. \& Balakrishnan, R. (2006). An evaluation of depth perception on volumetric displays. AVI., 193-200. 
Fisher, G.H. (1969). An experimental study of angular substension. Quarterly lournal of Psychology, 21, 356-366

Forsell, C. (2007). Perceptually Motivated Constraints on 3D Visualizations. Uppsala University, Uppsala.

Halle, M. (1997). Autostereoscopic Displays and Computer Graphics. In Computer Graphics, ACM SIGGRAPH, 31(2), 58-62.

Heywood, S. \& Chesselli K. (1977). Expanding Angles? Systematik distortions of space involving angular figures. Perception, 4, 571-582.

IJsselsteijn, W.A., Ridder, H. and Vliegen, J. (2000). Subjective Evaluation of Stereoscopic Images: Effects of Camera Parameters and Display Duration. IEEE Transactions on Circuits and Systems for Video Technology, 10(2), 225-233.

Lotto, R. B., Williams, S. M. \& Purves, D. (1999). An empirical basis for Mach bands. Proceedings of The National Academy Of Sciences, 96, 5239-5244.

Matusik, W. \& Pfister, H. (2004). 3D TV: A Scalable System for Real-Time Acquisition, Transmission, and Autostereoscopic Display of Dynamic Scenes. In Proceedings of SIGGRAPH, 814-824

Meng, J., Rieser, J.J \& Bodenheimer, B. (2006). Distance Estimation in Virtual Environments Using Bisection. ACM International Conference Proceeding Series, $153,146-146$

Ntuen, A.C., Goings, M., Reddin, M. \& Holmes, K. (2009). Comparison between 2$\mathrm{D} \&$ 3-D using an autostereoscopic display:The effects of viewing field and illumination on performance and visual fatigue. International Journal of Industrial Ergonomics, 39, 388-395

Nundy S., Lotto R.B., Coppola D., Shimpi A. \& Purves D. (2000) Why are angles misperceived? Proc Natl Acad Sci USA, 97, 5592-5597. 
Plumert, M.J., Kearney, J.K., Cremer, J.F \& Recker, K. (2005). Distance Perception in Real and Virtual Environments. ACM Transactions on Applied Perception, 2(3), 216-233.

Polti, A. (2006). Visual Stress and Performance using Autostereoscopic Displays. Unpublished semester dissertation, Swiss Federal Institute of Technology, Zurich.

Purves, D., Shimpi, A. \& Lotto, R. B. (1999). An Empirical Explanation of the Cornsweet Effect. The Journal of Neuroscience, 19(19), 8542-8551.

Rambli, A.R.D. \& Kalawsky, R.S. (2006). Distance estimations in static images: does viewing distance matter? ACM International Conference Proceeding Series, $158,17-23$

Sexton, I. \& Surman, P. (1999). Stereoscopic and autostereoscopic display systems. Signal Processing Magazine, IEEE, 16(3), 85-99

Williams, S.M., McKoy, A.N. \& Purves, D. (1998). The influence of depicted illumination on brightness. Proceedings of The National Academy Of Sciences, 95(22), 13296-13300.

Wundt, W. (1862) Beitra"ge zur Theorie der Sinneswahrnehmung. (Winter'sche Verlagshandlung, Leipzig, Germany).

Zone, R. (2007) Stereoscopic Cinema and The Origins of 3-D Film, 1838-1952. Kentucky: The University Press of Kentucky. 


\section{APPENDICIES}

\section{APPENDIX A: EXPERIMENT QUESTIONNAIRE}

\section{Deneyden Önce}
Cinsiyet
$\square$ Kadın
$\square$ Erkek

Yaş

Eğitim Durumu

$\square$ Lisans $\square$ Master $\square$ Doktora Diğer (

Meslek

Daha önce belirlenmiş görme probleminiz var mı?

$\square$ Evet $\quad \square$ Hayır

Okuma veya bilgisayar kullanırken gözlük yada lens gibi yardımcı araçlar kullanıyor musunuz?

$\square$ Evet $\quad \square$ Hayır $\quad$ (Eğer cevabınız evetse lütfen gözlüğünüzü takınız.)

Daha önce 3 boyutlu bir görüntü izlediniz mi?

$\square$ Evet $\quad \square$ Hayır

Eğer izlediyseniz hangi aparatları kullandınız (3B gözlük, kask vs.)? 
Ne kadar sıklıkla oyun oynarsınız?

Sürekli $\quad \square$ Haftada bir kere/Ayda birkaç kere $\quad \square$ Hiç Oynamam

Oynadığınız oyunlarda 2B model mi yoksa 3B modeller mi daha yoğunlukta?

$\square$ 2B $\quad \square 3 \mathrm{~B}$

Hangi tür oyunları oynamayı seviyorsunuz?

\section{Deney süresince}

Birazdan size gösterilecek ekranda 3B görüntü almaya çalışınız. Bunun icin başınızı hareket ettirerek en iyi bakış noktasını yakalayabilirsiniz. 3B görüntüyü algıladığınızda araştırmacıya bildiriniz. Yaklaşık 2 dakikalık slayt gösterisi sizin ekrana alışmanızı kolaylaştıracaktır. En az beş resime baktıktan sonra 3B görüntü aldıysanız sonlandırabilirsiniz.

Gördüğünüz şekil ilk bakışta neye benziyordu? (En fazla iki tane işaretleyebilirsiniz.)
$\square$ Kule
Kuyu
$\square$ Kubbe
$\square$ Tünel 
Gördüğünüz şeklin 3B bir cismin iz düşümü olduğunu düşünerek diğer kesitlerini çiziniz? Şeklin X eksenindeki iz düşümünü sorulardaki çizgi olarak kabul ediniz.

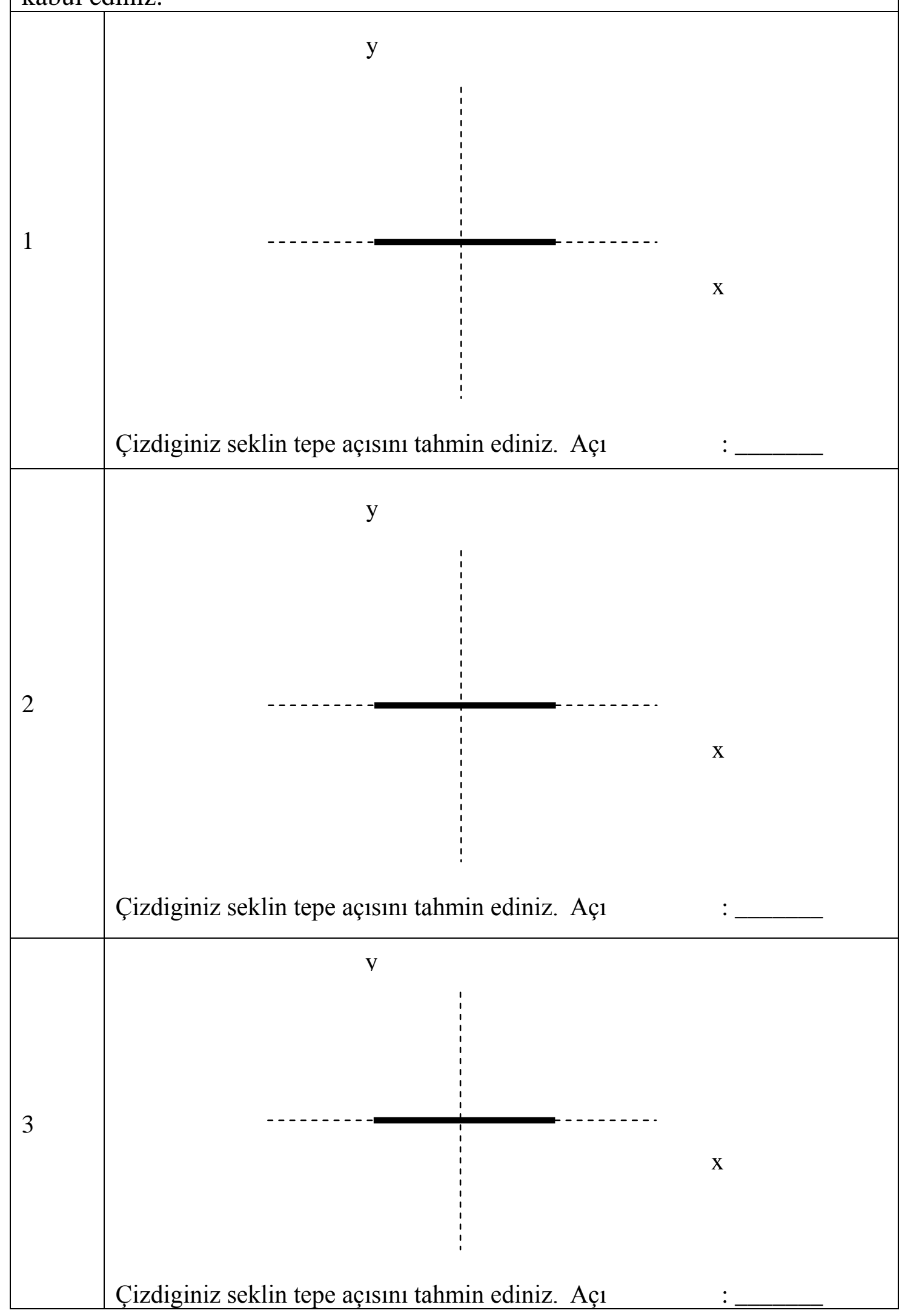


Gördüğünüz şeklin 3B bir cismin iz düşümü olduğunu düşünerek diğer kesitlerini çiziniz? Şeklin X eksenindeki iz düşümünü sorulardaki çizgi olarak kabul ediniz.

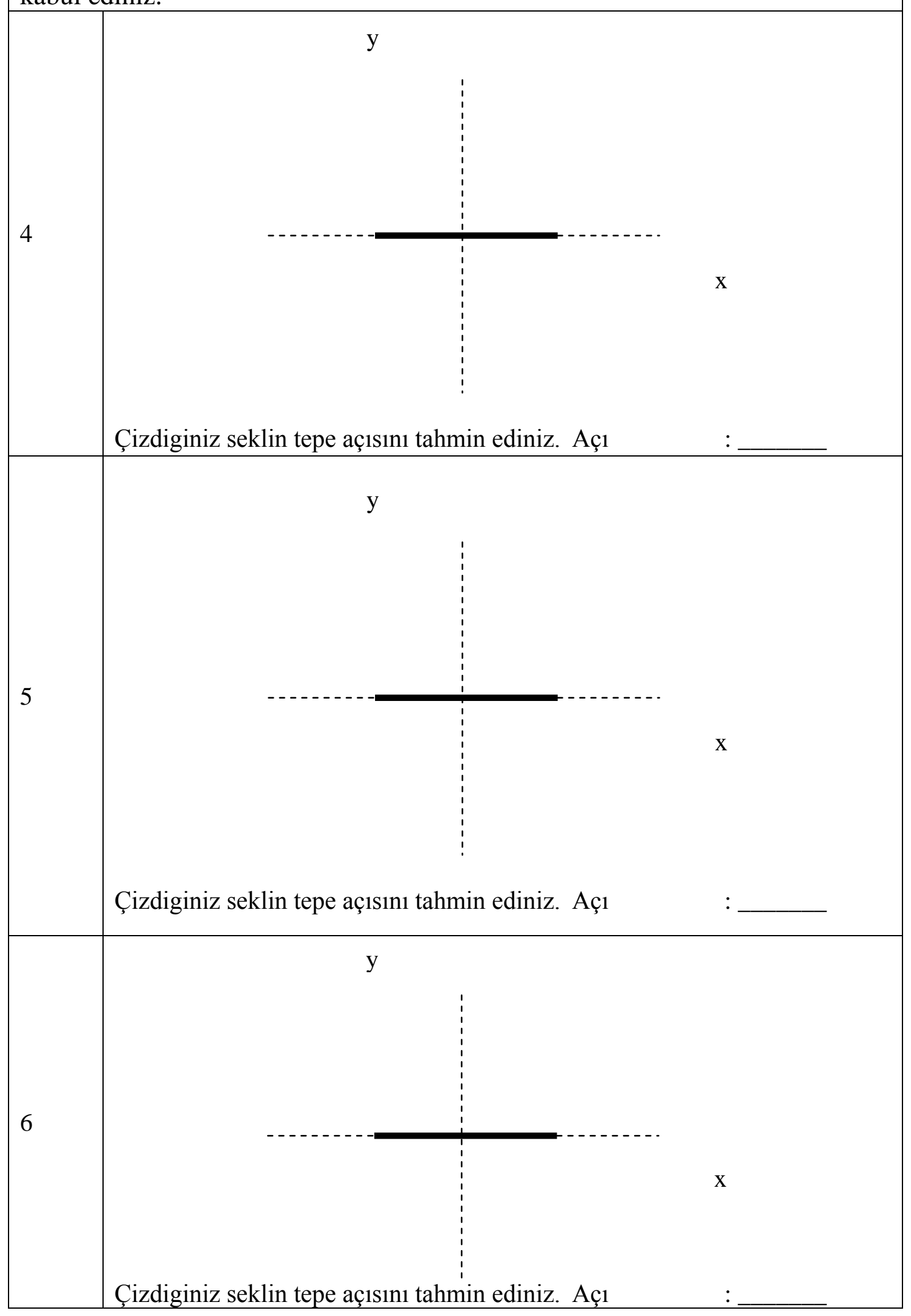


Gördüğünüz şeklin 3B bir cismin iz düşümü olduğunu düşünerek diğer kesitlerini çiziniz? Şeklin X eksenindeki iz düşümünü sorulardaki çizgi olarak kabul ediniz.

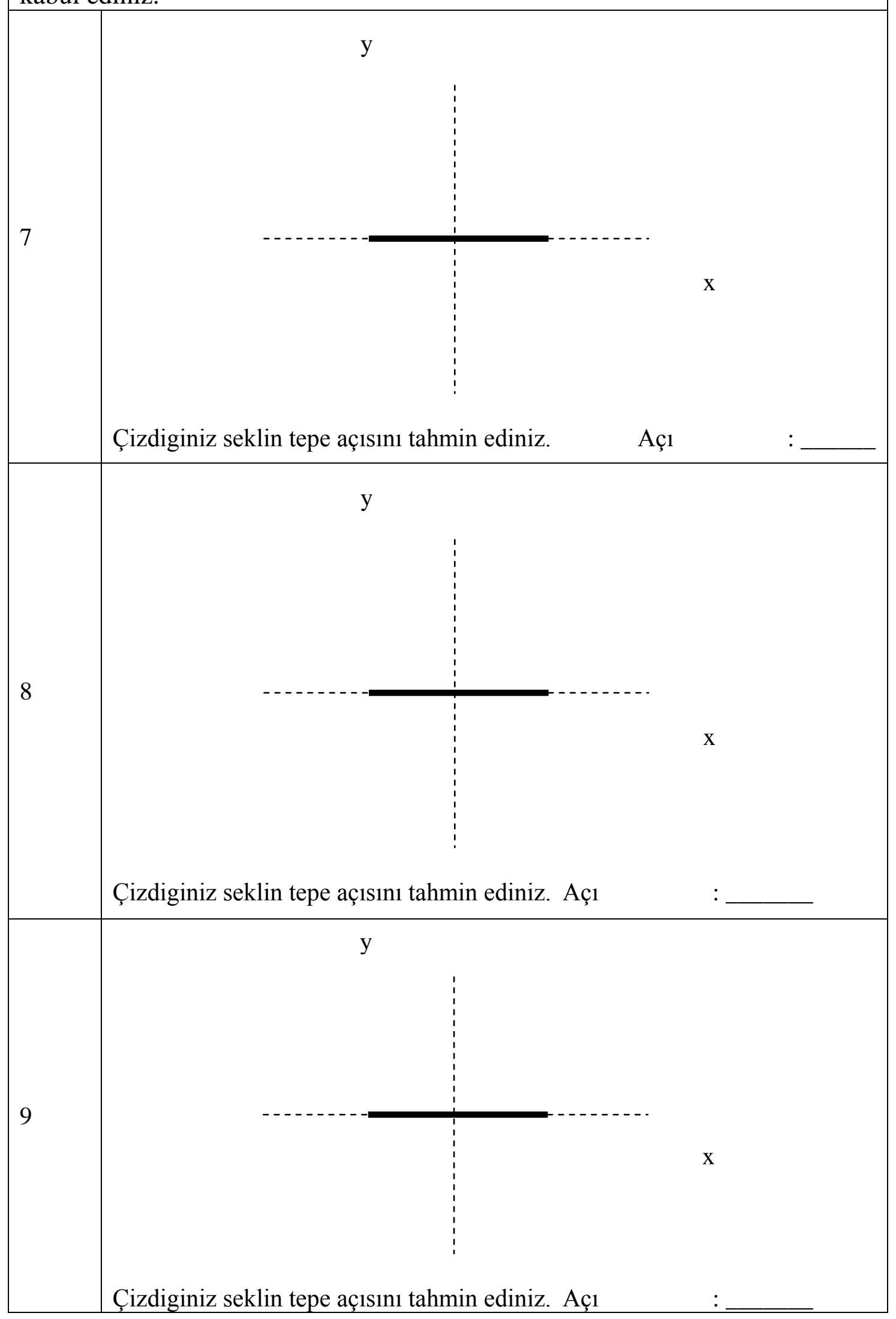


Gördüğünüz şeklin 3B bir cismin iz düşümü olduğunu düşünerek diğer kesitlerini çiziniz? Şeklin X eksenindeki iz düşümünü sorulardaki çizgi olarak kabul ediniz.

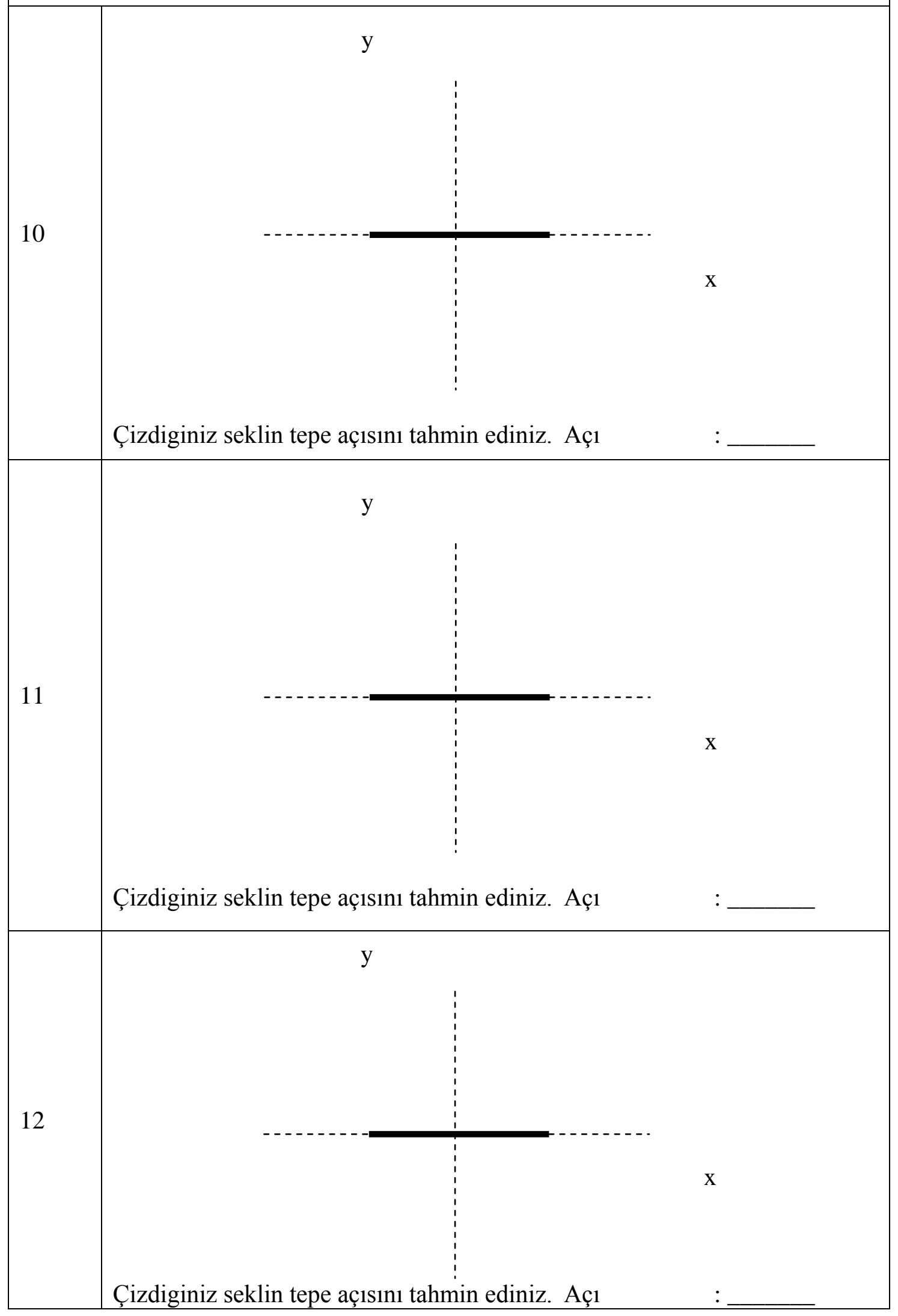


Gördüğünüz şeklin 3B bir cismin iz düşümü olduğunu düşünerek diğer kesitlerini çiziniz? Şeklin X eksenindeki iz düşümünü sorulardaki çizgi olarak kabul ediniz.

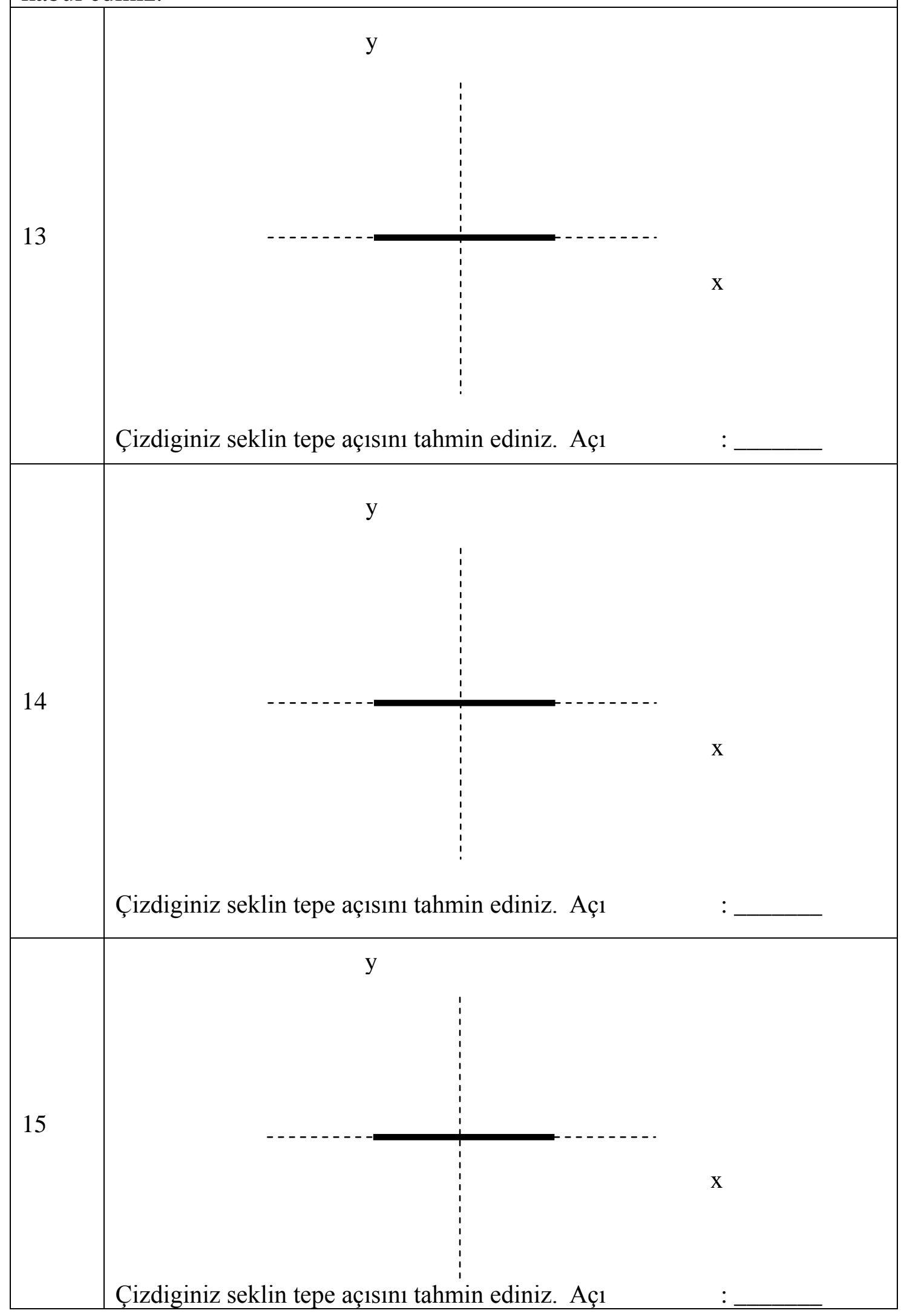


Gördüğünüz şeklin 3B bir cismin iz düşümü olduğunu düşünerek diğer kesitlerini çiziniz? Şeklin X eksenindeki iz düşümünü sorulardaki çizgi olarak kabul ediniz.

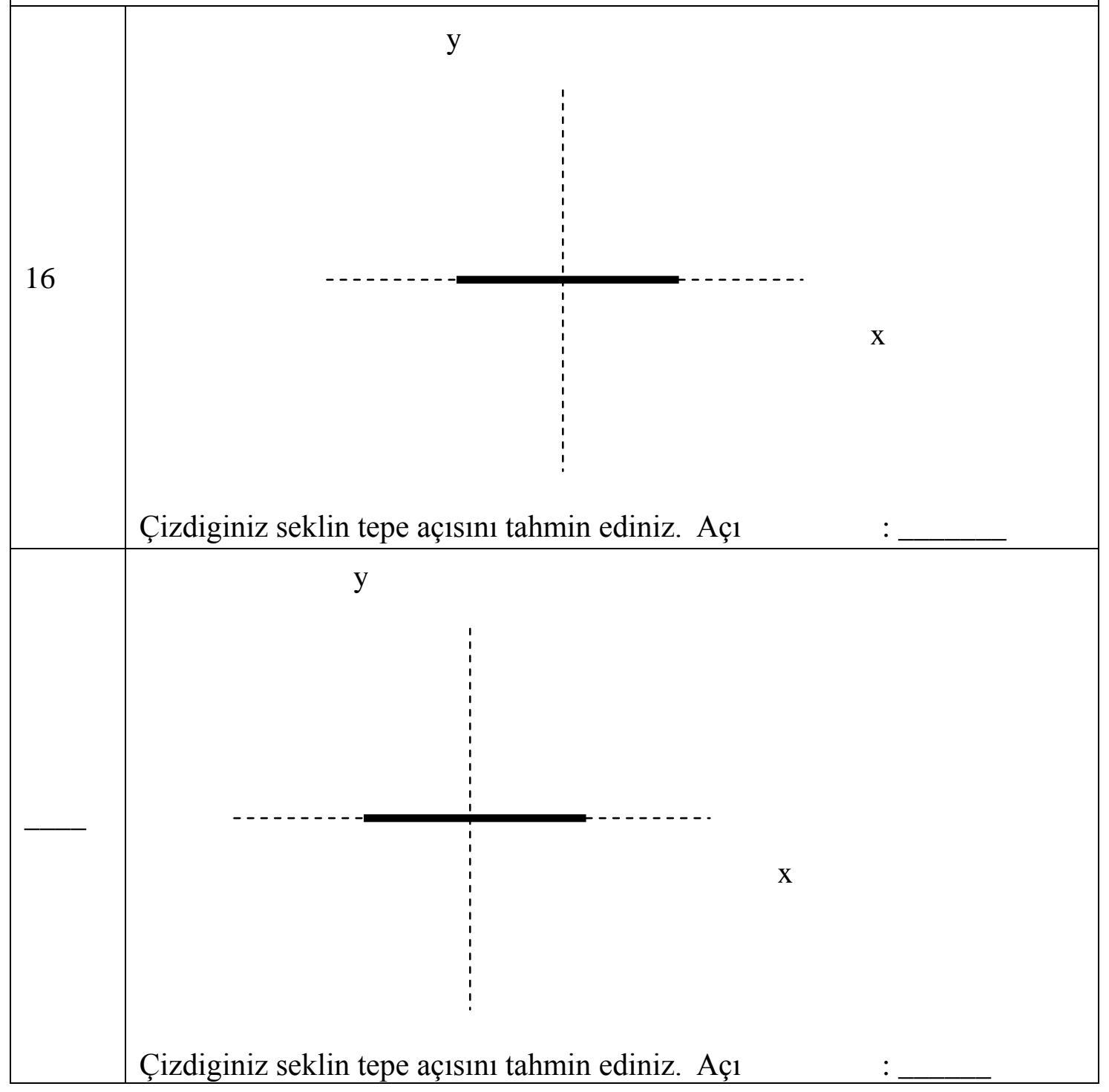




\section{Gercek Koniler İçin}

1. Size gösterilen koninin tepe açısını ve yüksekliğini tahmin ediniz.

Tepe Açısı

2. Size gösterilen koninin tepe açısını ve yüksekliğini tahmin ediniz.

Tepe Açıs1

3. Size gösterilen koninin tepe açısını ve yüksekliğini tahmin ediniz.

Tepe Açısı

4. Size gösterilen koninin tepe açısını ve yüksekliğini tahmin ediniz.

Tepe Açıs1

5. Size gösterilen koninin tepe açısını ve yüksekliğini tahmin ediniz.

Tepe Aç1s1

6. Size gösterilen koninin tepe açısını ve yüksekliğini tahmin ediniz.

Tepe Açısı

7. Size gösterilen koninin tepe açısını ve yüksekliğini tahmin ediniz.

Tepe Açısı

8. Size gösterilen koninin tepe açısını ve yüksekliğini tahmin ediniz.

Tepe Açısı 


\section{Deney Sonrasi}

2B, 3B ve Gerçek Ortam da yaptığınız açı tahminlerini isabetlilik bakımından siralayızı.

1)

2)

3)

2B, 3B ve Gerçek Ortamı etkileyicilik/ kendine bağlayıcılık (immersiveness) açısından sıralayınız.

1) 2) 3)

Sizce bu tür ekranlar hangi amaçlarla kullanılabilir? 


\section{APPENDIX B: PARTICIPANT CONSENT FORM}

\section{Gönülü Katılım Formu}

$\mathrm{Bu}$ çalışma, Bilişim Sistemleri Ana Bilim Dalı Araştırma Görevlisi Ersin KARAMAN'ın yüksek lisans tezi kapsamında yapılan bir çalışmadır. Yardımcı aparat gerektirmeden 3B görüntü sağlayan autostereoskopik ekranların hissttirdiği derinlik algısının, geleneksel 2B ekranlarla karşılaştırılması çalışmamızın temel amacıdır. Çalışmaya katılım tamimiyle gönüllülük temelinde olmalıdır. Çalışmada, sizden kimlik belirleyici hiçbir bilgi istenmemektedir. Verileriniz tamamiyle gizli tutulacak ve sadece araştırmacılar tarafindan değerlendirilecektir; elde edilecek bilgiler bilimsel yayımlarda kullanılacaktır.

Katılımcılardan autostereoskopik ekranlarda gördükleri nesnelerin izdüşümleri ni çizmeleri ve tepe açılarını tahmin etmeleri beklenmektedir. Uygulamanın yaklaşık olarak 30 dakika sürmesi beklenmektedir. Uygulamanın kişiler üzerinde fiziksel ya da ruhsal rahatsızlık vermesi beklenmemektedir. Ancak, uygulama sırasında bilgisayar düzeneğinden ya da herhangi başka bir nedenden ötürü kendinizi rahatsız hissederseniz uygulamayı yarıda bırakıp çıkmakta serbestsiniz. Böyle bir durumda çalışmayı uygulayan kişiye, uygulamayı tamamlamadığınızı söylemek yeterli olacaktır. Uygulama sonunda, bu çalışmayla ilgili sorularınız cevaplanacaktır. $\mathrm{Bu}$ çalışmaya katıldığınız için şimdiden teşekkür ederiz. Çalışma hakkında daha fazla bilgi almak için Bilişim Sistemleri Anabilim dalı öğrencisi Arş. Gör. Ersin KARAMAN'a (Oda: II B/107; Tel: 210 7224; E-posta: ersin@ii.metu.edu.tr) ile iletişim kurabilirsiniz.

Bu çalışmaya tamamen gönüllü olarak katıllyorum ve istediğim zaman yarıda kesip çıkabileceğimi biliyorum. Verdiğim bilgilerin bilimsel amaçlı yayımlarda kullanılmasını kabul ediyorum. (Formu doldurup imzaladıktan sonra uygulayıcıya geri veriniz).

İsim Soyad

Tarih

İmza

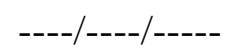




\section{APPENDIX C: DE-BRIEF FORM}

\section{KATILIM SONRASI BILLGI FORMU}

Bu çalışma daha önce de belirtildiği gibi ODTÜ Enformatik Enstitüsü Bilişim Sistemleri AnaBilim Dalı öğrencilerinden Ersin KARAMAN'ın yüksek lisans tezi kapsamında yapılmaktadır. Çalışmada autostereoskopik ekranlarda derinlik algısı incelenecektir.

Yardımc1 aparat gerektirmeden 3B görüntü sağlayan autostereoskopik ekranların hissettirdiği derinlik algısının, geleneksel 2B ekranlarla karşılaştırılması çalışmamızın temel amacıdır. Autostereoskopik ekranlar her ne kadar henüz günlük hayatımıza girmemiş olsada hızla gelişen bir teknoloji olduğu bir gerçektir ve çok yakın gelecekte vitrinlerde ki yerinni alacağı tahmin edilmektedir.

Bu çalışmadan alınacak ilk verilerin Haziran 2009 sonunda elde edilmesi amaçlanmaktadır. Elde edilen bilgiler sadece bilimsel araştırma ve yazılarda kullanılacaktır. Çalışmanın sonuçlarını öğrenmek ya da bu araştırma hakkında daha fazla bilgi almak için aşağıdaki isime başvurabilirsiniz. Bu araştırmaya katıldığınız için tekrar çok teşekkür ederiz.

Arş. Gör. Ersin KARAMAN (Oda: II, B Blok, 107, ODTÜ; Tel: 21077 24; ersin@ii.metu.edu.tr) 


\section{APPENDIX D: PILOT STUDY QUESTIONNAIRES}

\section{Before Experiment}

Gender

:__ Female

Male

Age

Education Level

Occupation

1) Do you have vision problem prognosed before? If you have, are you using additional aids such as glasses?

2) Have you ever watched 3D stereo images or movies. If you have, what type of equipment have you used?

Yes

No

3D glasses

Head-Gear

Other $(\ldots \ldots \ldots \ldots \ldots . . . . .$.

3) How often do you play computer games?

4) Can you estimate the distance between you and the short wall of this hall. How many meters is it? ( ) $\mathrm{m}$

5) Can you estimate the distance between you and the long wall of this hall. How many meters is it? ( ) m

6) Have you strategized your estimation? 


\section{During Experiment}

7) Please find the 'sweet-spot' as quickly as possible.

8) Now you are going to be presented a slide show, please evaluate these images from 1 to 5 which means very bad to very good in terms of 3D stereo perception. You can end the slideshow whenever you want.

\begin{tabular}{|l|l|l|l|l|l|}
\hline & 1 & 2 & 3 & 4 & 5 \\
\hline Image01 & & & & & \\
\hline Image02 & & & & & \\
\hline Image03 & & & & & \\
\hline Image04 & & & & & \\
\hline Image05 & & & & & \\
\hline Image06 & & & & & \\
\hline Image07 & & & & & \\
\hline Image08 & & & & & \\
\hline Image09 & & & & & \\
\hline Image10 & & & & & \\
\hline Image11 & & & & & \\
\hline Image12 & & & & & \\
\hline Image13 & & & & & \\
\hline Image14 & & & & & \\
\hline Image15 & & & & & \\
\hline Image16 & & & & & \\
\hline Image17 & & & & & \\
\hline Image18 & & & & & \\
\hline Image19 & & & & & \\
\hline Image20 & & & & & \\
\hline Image21 & & & & & \\
\hline Image22 & & & & & \\
\hline Image23 & & & & & \\
\hline Image24 & & & & & \\
\hline
\end{tabular}


9) What is the shape you are looking at is like?

10) Do you think this shape is:

Concave

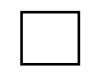

Convex

11) Can you draw this shape's profile by assuming that it is the projection of a $3 \mathrm{D}$ objects?

12) Can you estimate the vertex of this profile?

13) Now the same shape is shown on $3 \mathrm{D}$ mode. Can you draw this shape's profile again?

14) Can you estimate the vertex of this shape you have drawn?

Can you estimate the length and radius of the tower? Have you ever seen this building in real life?

16) Can you estimate the distance between the walls in this image.

This questioned is asked randomly to subjects with 2D and 3D. What is the mode of display? ) $2 \mathrm{D}$ $3 \mathrm{D}$ 


\section{After Experiment}

17) Can you compare images which were shown in slide by using TreDef image viewer and 3D models shown by using Google Earth in terms of 3D stereo perception?

18) Can you compare this device and other displays you used in terms of $3 \mathrm{D}$ perception?

19) Have you strategized your distance estimation on virtual environment? Please explain.

Thank you for your participation.

Ersin KARAMAN

ersin@ii.metu.edu.tr 


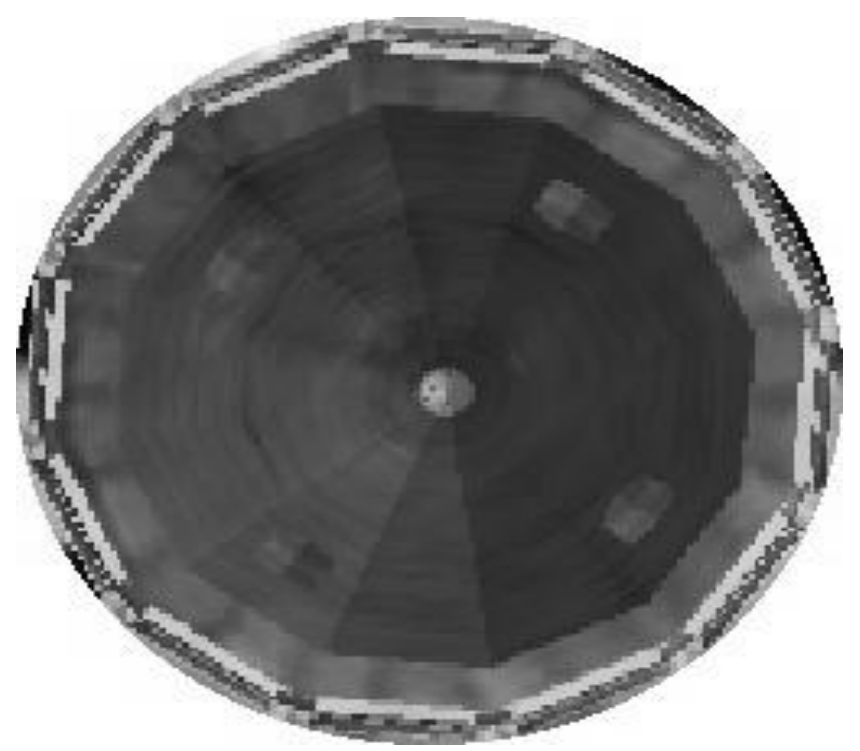

Figure 26: View of the object from top

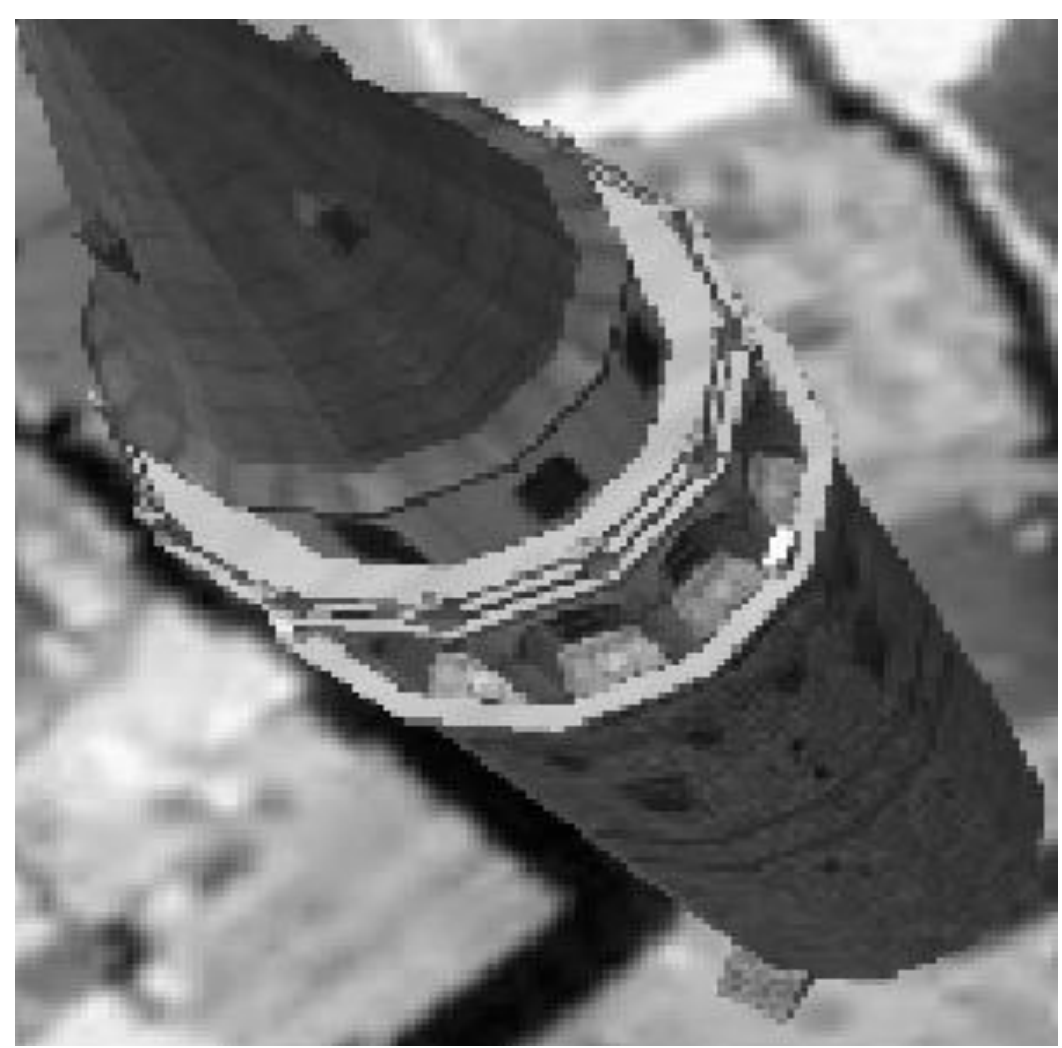

Figure 27: View of the object from a height of 100m. and tilted at an angle of 15 degrees to object base 


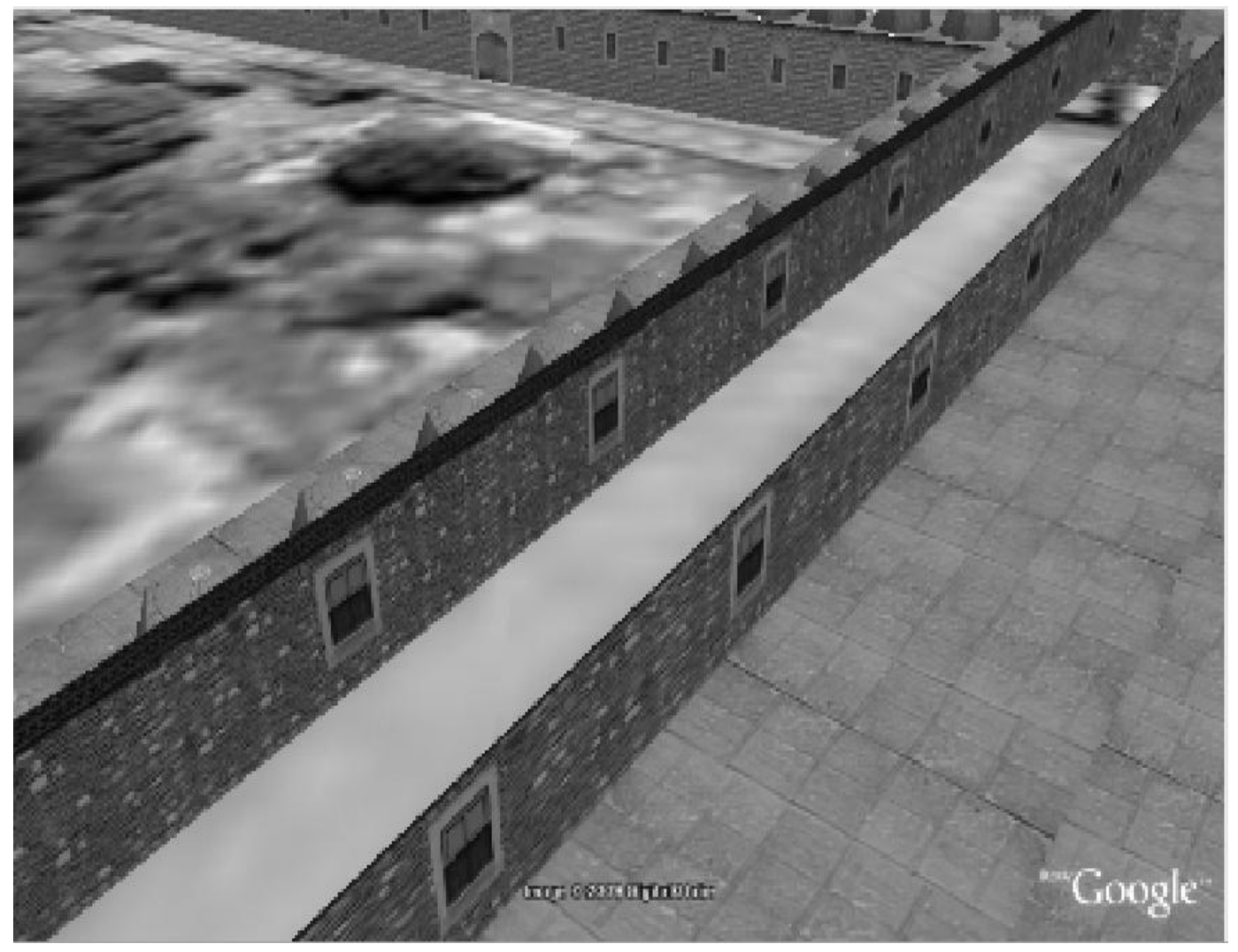

Figure 28: View of the object from a height of $45 \mathrm{~m} . \mathrm{s}$ and tilted at an angle of 60 degrees to object base 


\section{APPENDIX E: LEARNING EFFECT}

Two-way ANOVA: Value versus Run; Subject

$\begin{array}{lrrrrr}\text { Source } & \text { DF } & \text { SS } & \text { MS } & F & P \\ \text { Run } & 23 & 41149 & 1789,1 & 1,39 & 0,103 \\ \text { Subject } & 39 & 451189 & 11569,0 & 9,02 & 0,000 \\ \text { Error } & 897 & 1150913 & 1283,1 & & \\ \text { Total } & 959 & 1643252 & & & \\ \text { S }=35,82 & \text { R-Sq }=29,96 \% & R-S q(\text { adj }) & =25,12 \%\end{array}$

\section{Residual Plots for Value}
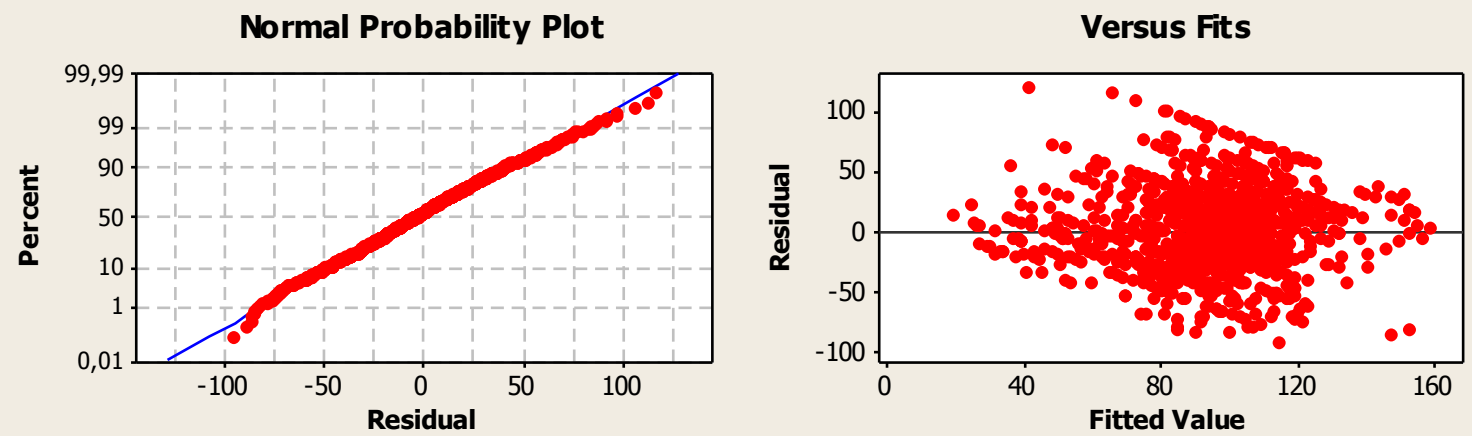

Histogram

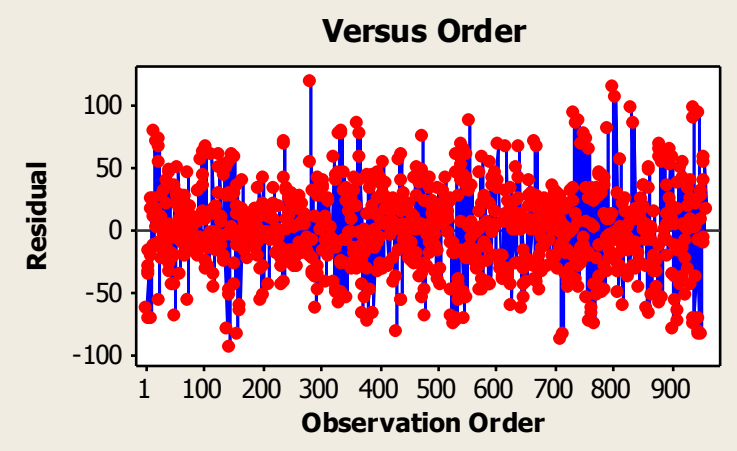




\section{APPENDIX F: GENERAL VIEW OF EXPERIMENT RESULT}

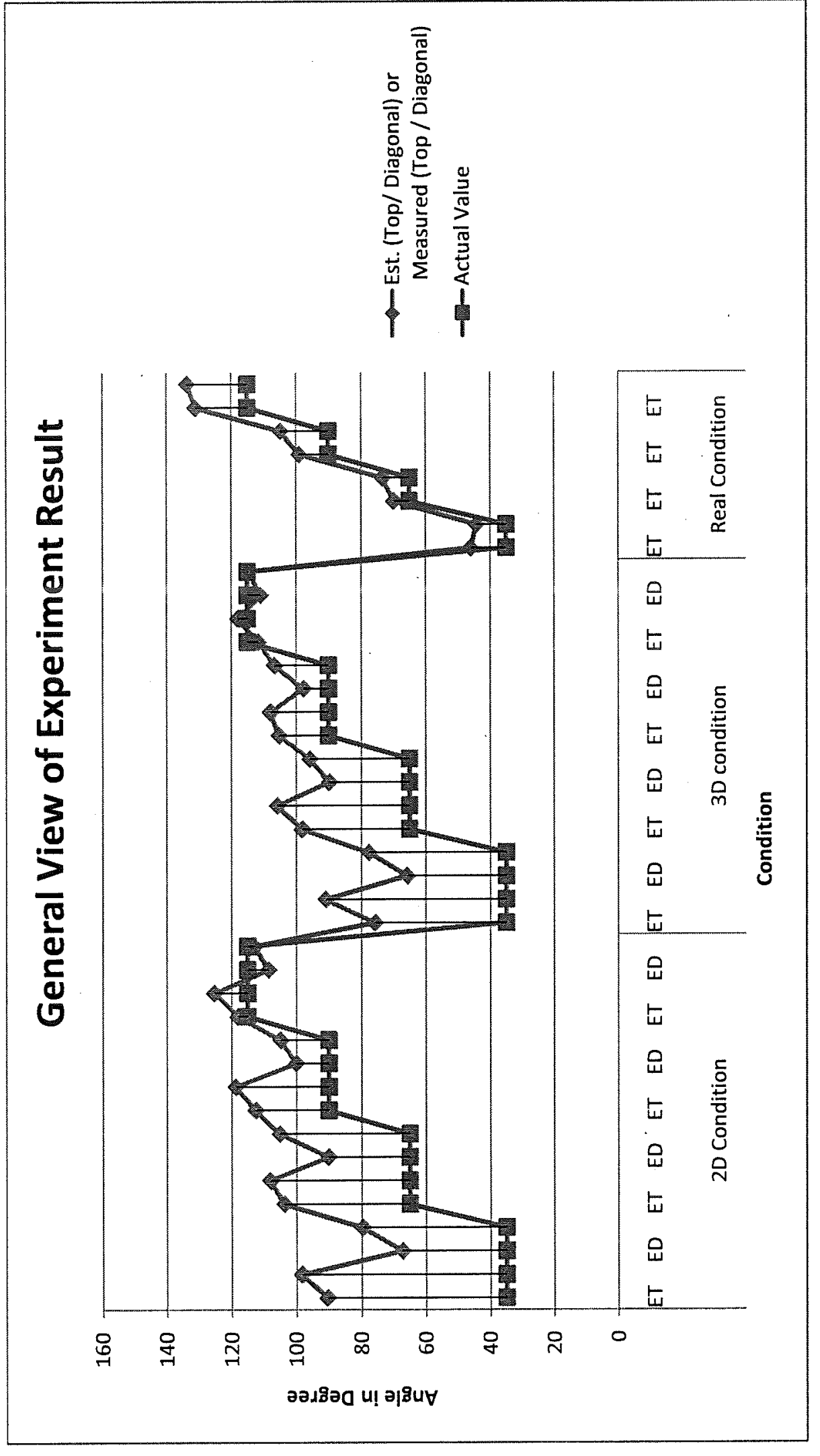

 


\section{APPENDIX G: A SAMPLE PROJECTION}

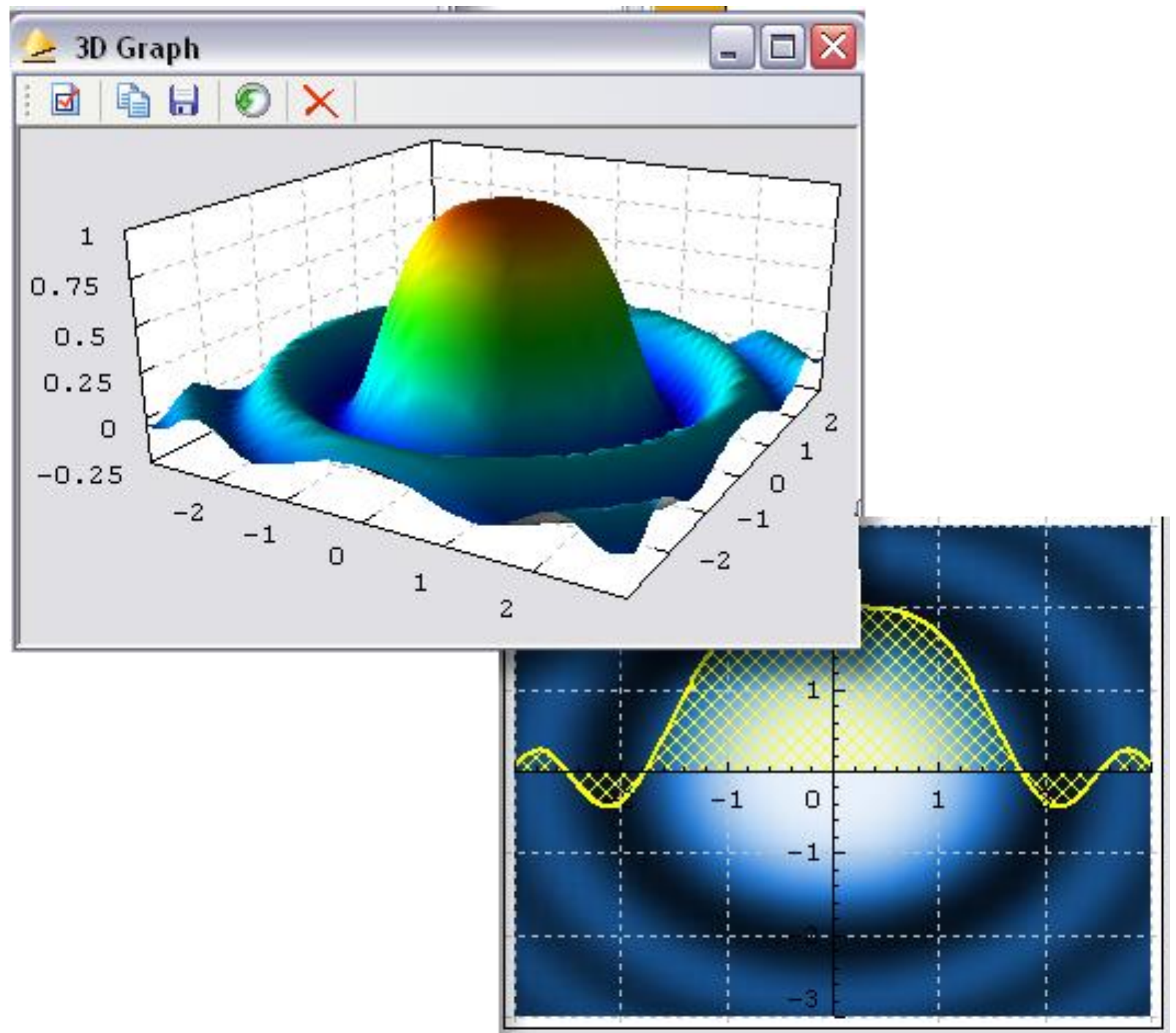

Figure 30: Sample Projection (http://www.astrise.com/images/algebr01.png) 


\section{APPENDIX H: SAMPLE 3D AND 2D MODEL}
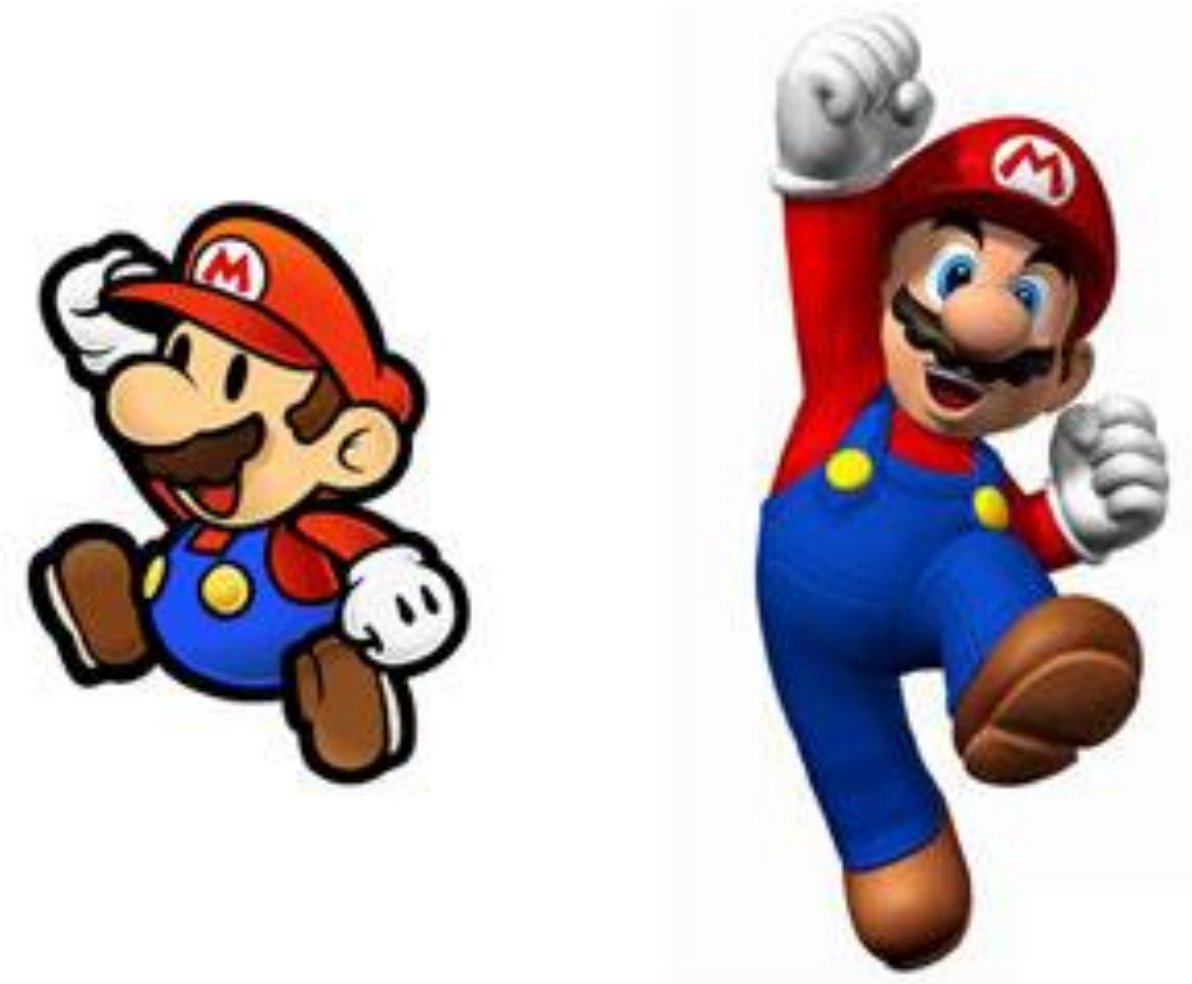

Figure 31: 2D vs 3D Model (http://www.media-freaks.com/squidoopics/3danimationstudio/mario2d3d.jpg)

2D Model

3D Model 


\section{APPENDIX I: DETAIL ANALYSIS FOR EACH ANGLE}

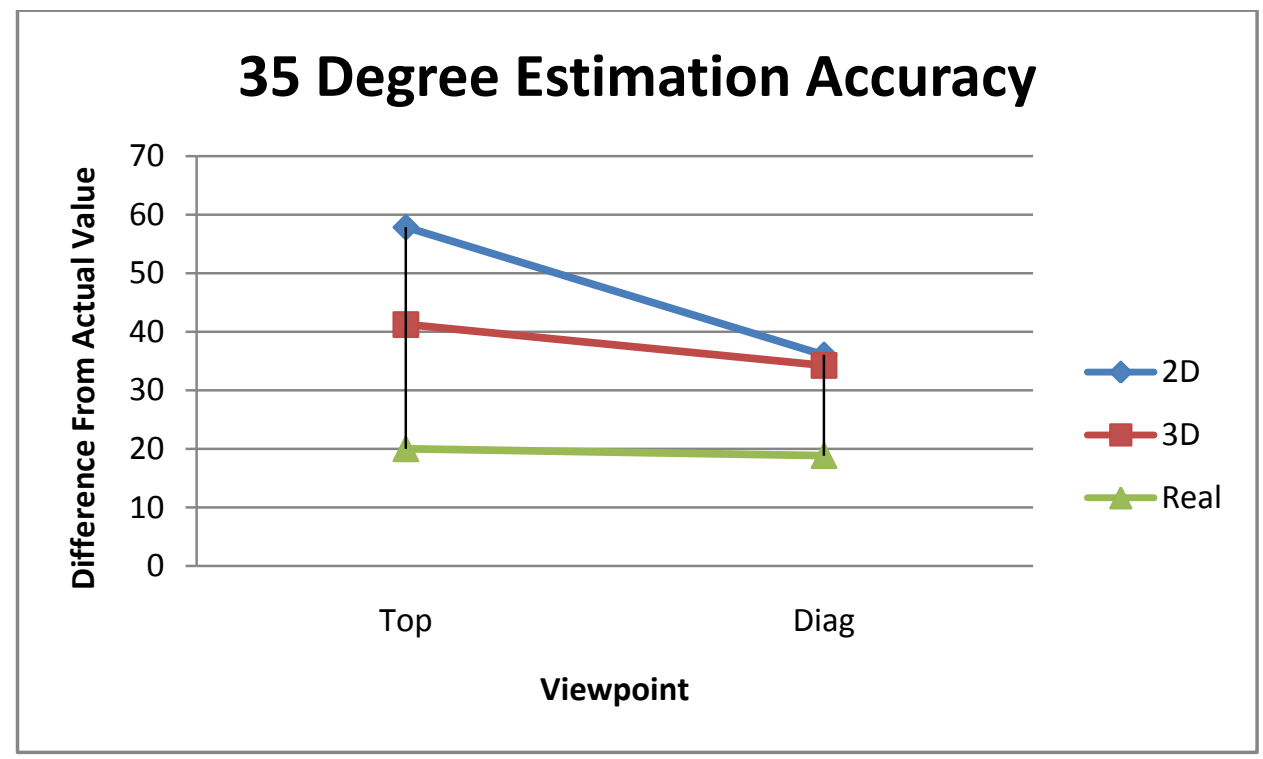

Figure 32: 35 Degree Estimation Accuracy

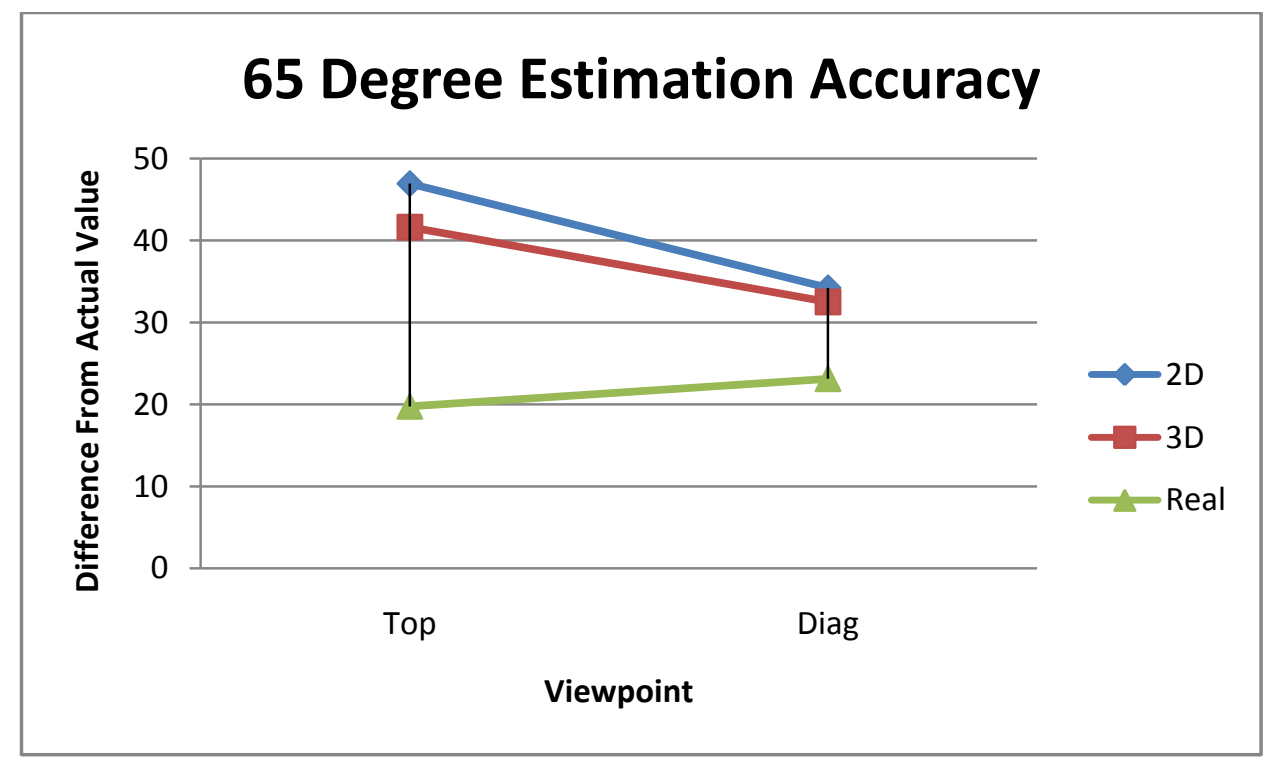

Figure 33: 65 Degree Estimation Accuracy 


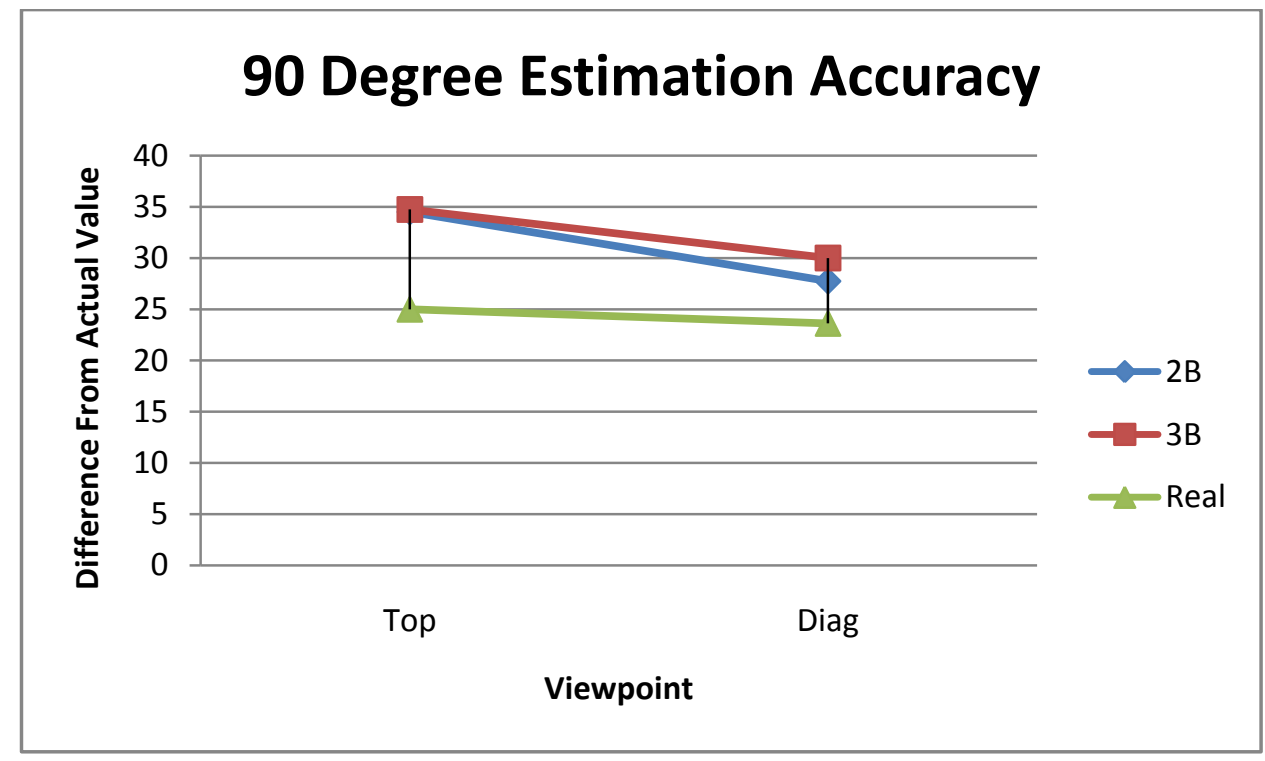

Figure 34: 90 Degree Estimation Accuracy

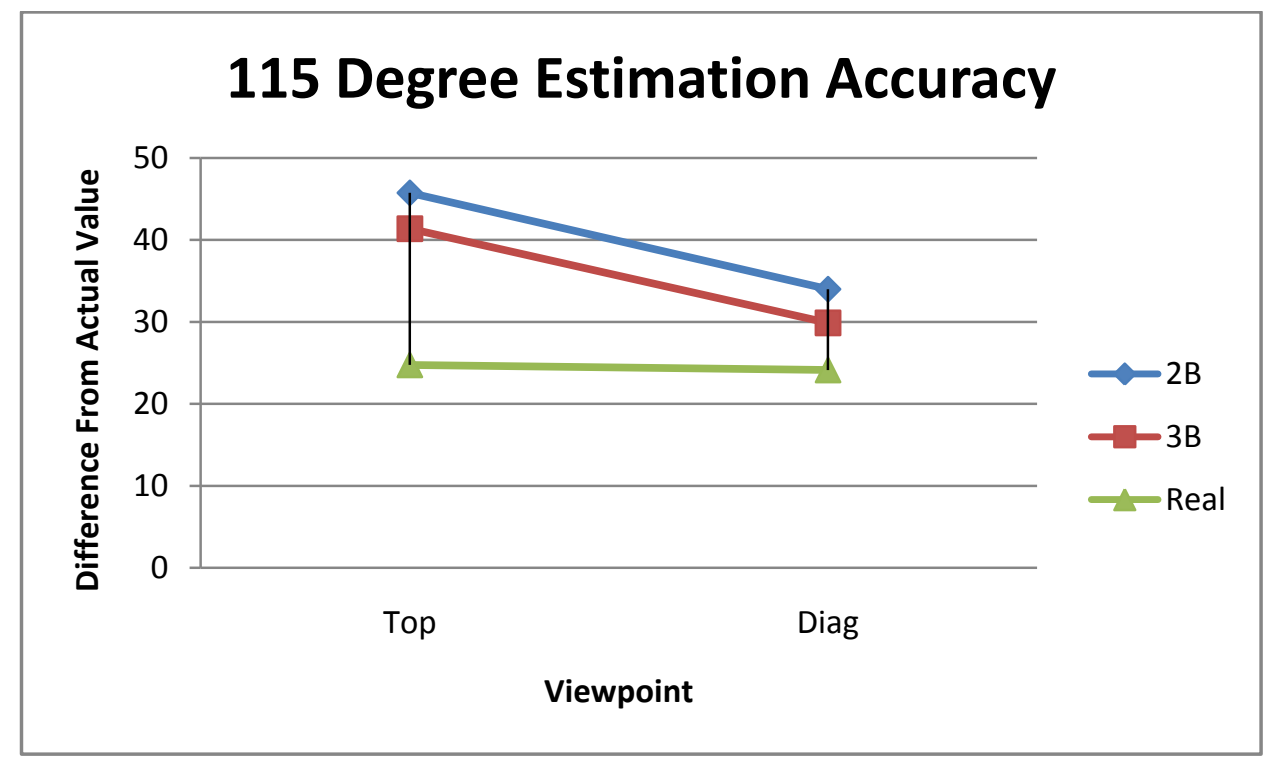

Figure 35: 115 Degree Estimation Accuracy 


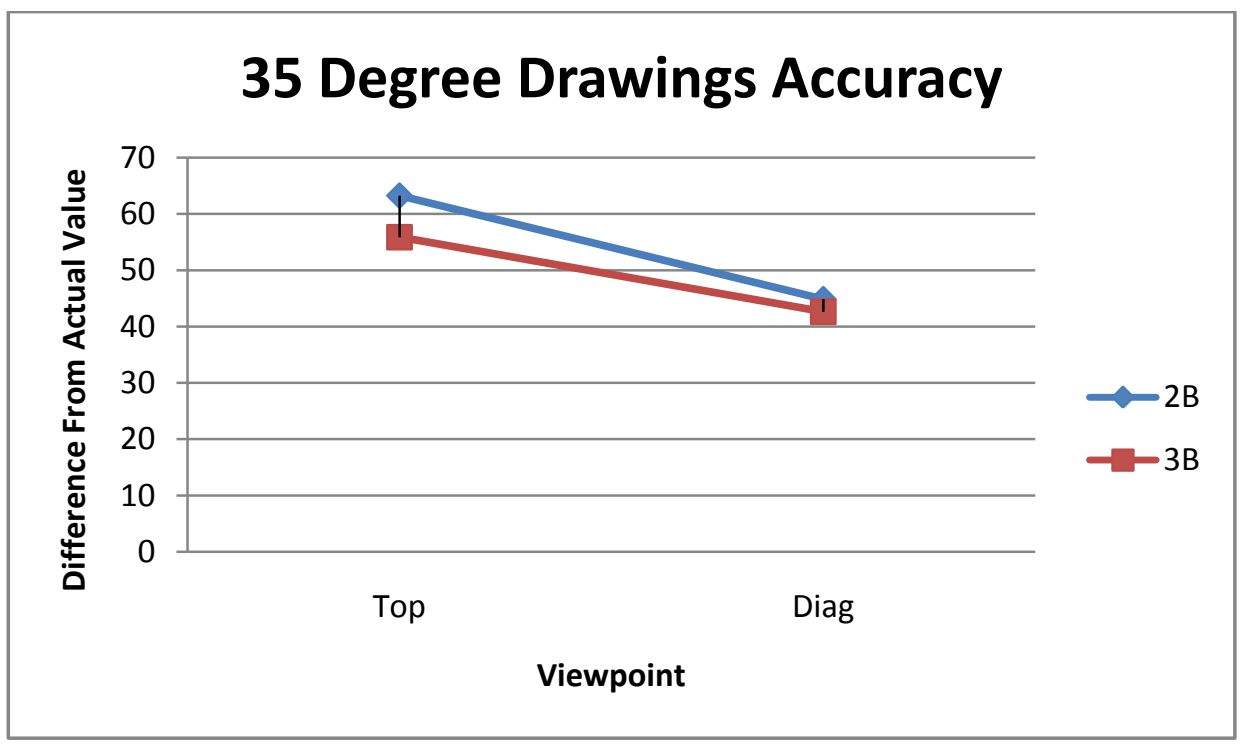

Figure 36: 35 Degree Drawings Accuracy

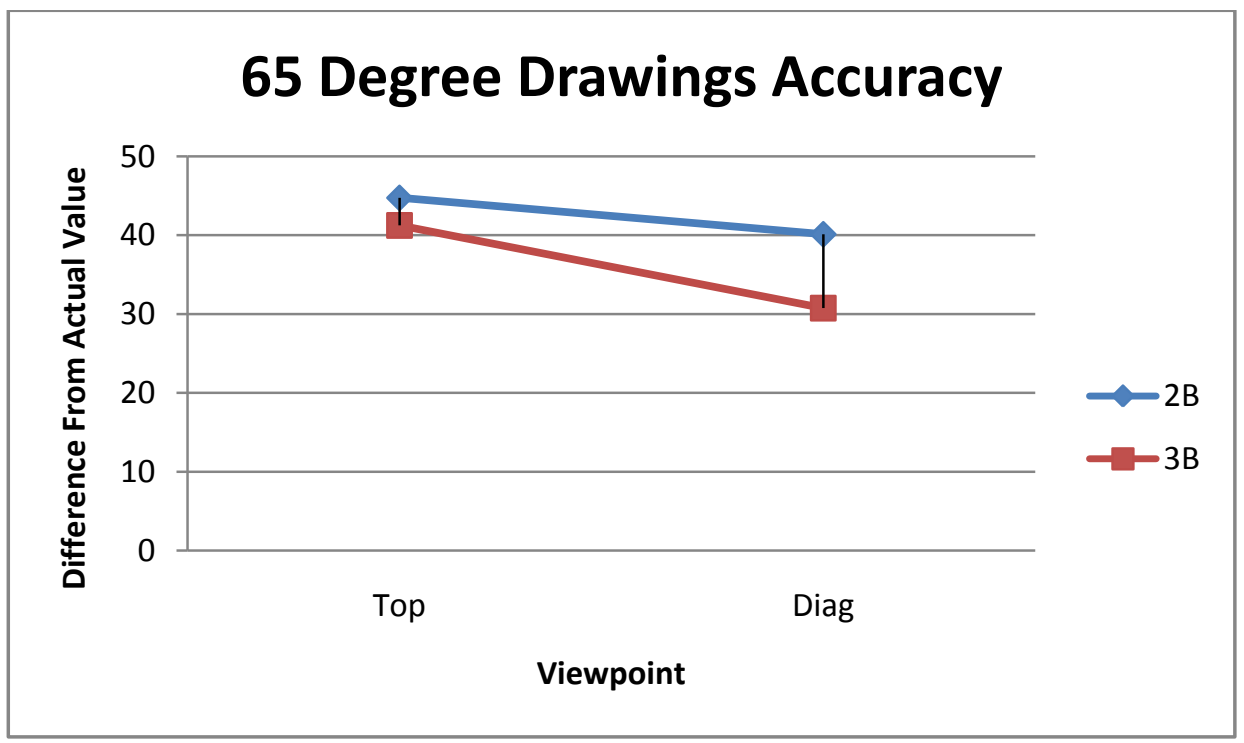

Figure 37: 65 Degree Drawings Accuracy 


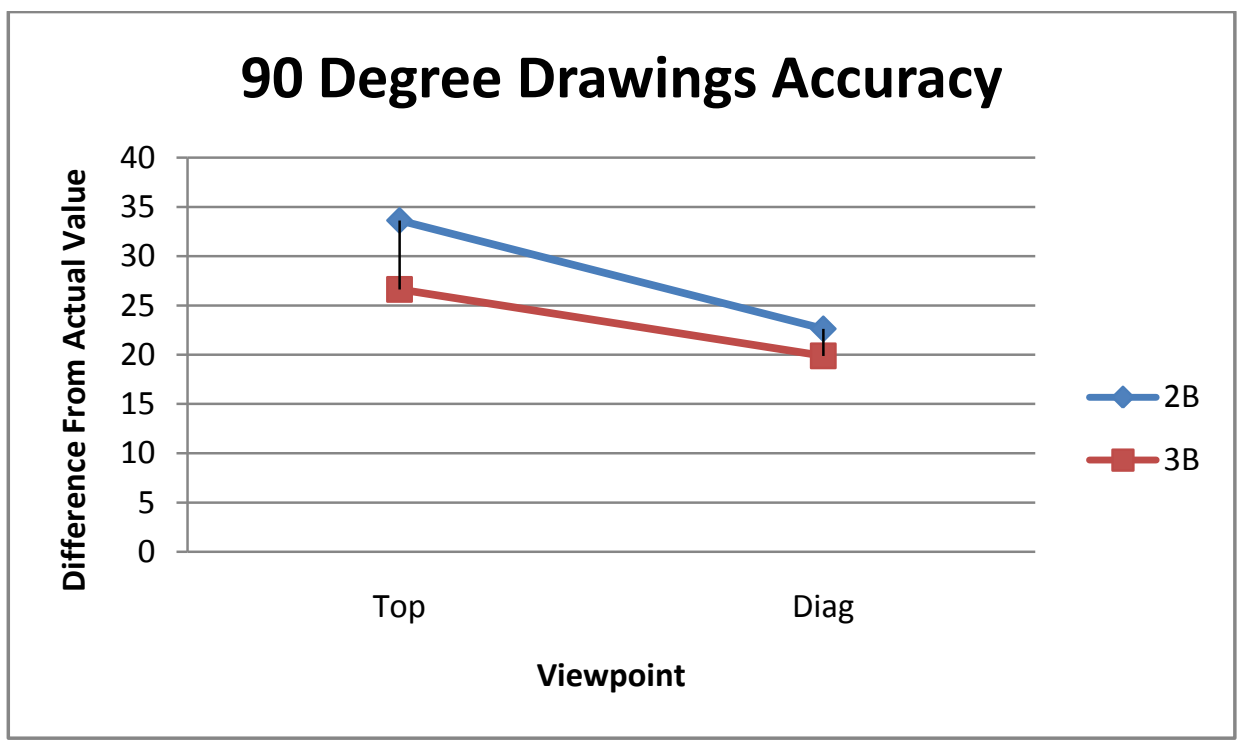

Figure 38: 90 Degree Drawings Accuracy

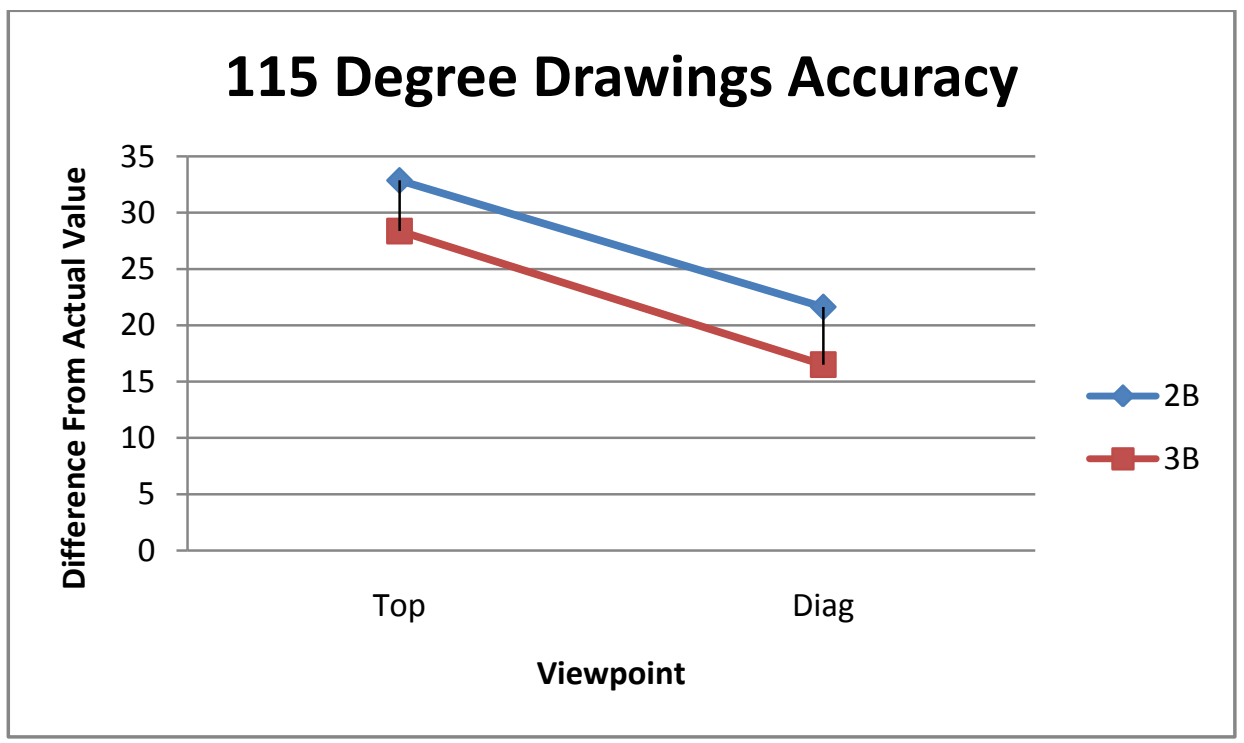

Figure 39: 115 Degree Drawings Accuracy 